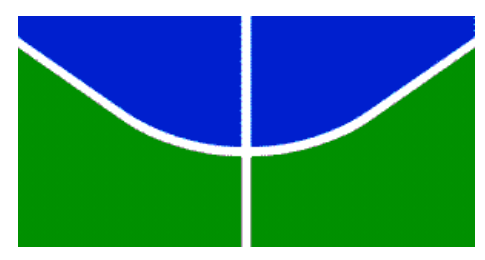

\author{
Universidade de Brasília \\ Instituto de Relações Internacionais \\ Programa de Pós-Graduação em Relações Internacionais
}

\title{
Brasil, País do Futuro: A Ascensão Internacional Brasileira sob a Perspectiva Realista das Relações Internacionais.
}

Saint-Clair Lima da Silva

Brasília 


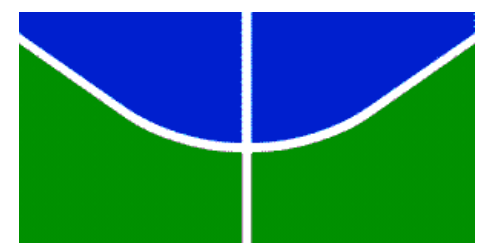

Universidade de Brasília

Instituto de Relações Internacionais

Programa de Pós-Graduação em Relações Internacionais

\section{Brasil, País do Futuro: A Ascensão Internacional Brasileira sob a Perspectiva Realista das Relações Internacionais.}

\section{Saint-Clair Lima da Silva}

Dissertação apresentada ao Programa de Pós Graduação em Relações Internacionais da Universidade de Brasília como requisito parcial para a obtenção do grau de Mestre.

Área: Relações Internacionais - Política Internacional e Comparada.

Orientadora: Dra. Norma Breda dos Santos

\section{Brasília}




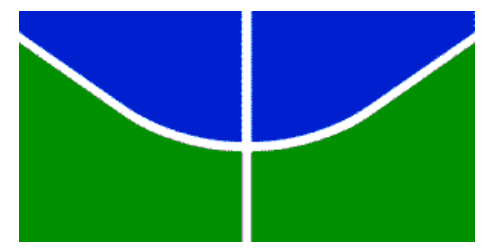

Universidade de Brasília

Instituto de Relações Internacionais

Programa de Pós-Graduação em Relações Internacionais

Defesa da dissertação de mestrado de Saint-Clair Lima da Silva, intitulada: "Brasil, País do Futuro: A Ascensão Internacional Brasileira sob a Perspectiva Realista das Relações Internacionais", orientado pela Professora Norma Breda dos Santos, apresentada à banca examinadora designada pelo Colegiado do Programa de Pós Graduação em Relações Internacionais da Universidade de Brasília, em 04 de março de 2015.

Os membros da Banca Examinadora consideraram o candidato Saint-Clair Lima da Silva APROVADO.

\section{Banca Examinadora:}

Dra. Norma Breda dos Santos - Instituto de Relações Internacionais da UnB

Dr. Virgílio Caixeta Arraes - Departamento de História da UnB

Dr. Marco Aurélio Chaves Cepik - Centro de Estudos Internacionais sobre Governo da UFRGS 


\section{ACKNOWLEDGEMENTS}

This work would never have been completed had it not been for the help and assistance of countless friends and colleagues. All the readings, discussions, observations and reflection have left a mountainous accumulation of debts. Here I can acknowledge only a few.

Conciliate our job with a master's program is not an easy task, and I am grateful for the constant support I had from my colleagues at Brazilian Air Force. An individual acknowledge is necessary to Major-Brigadier José Magno Rezende de Araujo, the officer who greatly contributed to make this possible.

I must thank the professors, my peers and the staff at Massachusetts Institute of Technology, where in a short, but intense period of studies, I finally learned to value theoretical framework and the power of methods. A special acknowledge to Professor Barry Posen, Director of MIT Security Studies Program, for his valuable insights and encouragement to this work.

I would like to record my special obligation to my dearest friend, Professor Pio Penna, who encouraged me to deepen my academic studies, and whose classes provided the necessary stimulus for that.

I am greatly indebted to my advisor, Professor Norma Breda, a friend and a mentor, for her patience, persistence, and for priceless advice and assistance. Her silent confidence in my work were the strength I needed in innumerous occasions.

I must thank my brothers Vladimir and Leandro, and my dear mother Zilda. They are my eternal and loved supporters.

My gratitude to my wife, Gislene, who had the strength and patience to support my enterprise and her own, whose insights constantly helped me to clarify my ideas and saved me from error, and whose love and care made this project possible.

To Lucas, who is always there to bring me love and smiles even on my toughest days.

And God, I would like to express my sincere gratitude for allowing these wonderful persons to be part of my life. 
To My Father.

For all that he taught me.

For all that he did for me.

For everything I wish I could have said to him. 


\section{RESUMO}

Brasil, País do Futuro é uma expressão criada em 1941 para indicar o potencial brasileiro para se tornar uma grande potência. Após um extenso adiamento dessa previsão, o período que abrange o final dos anos 2000 e início dos anos 2010 viu, finalmente, o país libertado do seu rótulo de "Terceiro Mundo" e seu crescimento consistente em status geopolítico.

As lideranças brasileiras - apoiadas pela constituição nacional - apresentam um discurso de paz e cooperação como principal proposta de abordagem do sistema internacional. O realismo estrutural, no entanto, prevê que a postura internacional de um país será guiada, principalmente, pela dinâmica de poder e por questões práticas e materiais, após sua ascensão ao "clube" das grandes potências.

Este trabalho tem como objetivo avaliar em que medida o crescimento da estatura brasileira no sistema internacional está sendo realizada de acordo com a teoria neorrealista. A fim de alcançar este objetivo, os principais conceitos neorrealistas são explorados e agregados em uma representação de suas principais variáveis em uma cadeia causal. Este quadro é então contrastado à postura internacional do Brasil em três fases: primeiro, confirmamos a mudança no poder relativo do Brasil, que é a responsável por ativar o processo; em seguida, avaliamos os fatores intervenientes na cadeia causal, ou seja, o ambiente doméstico do Brasil, as ameaças percebidas para a sua segurança, e os objetivos principais brasileiros no sistema internacional; finalmente, nós verificamos se as variáveis intervenientes atuaram para desenvolver uma postura revisionista na política externa do Brasil.

Prosseguindo na cadeia causal, avaliamos se há um esforço perceptível para o fortalecimento da capacidade militar brasileira e de alianças externas como evidências de que o país está, de fato, começando a "emular" o comportamento das grandes potências para enfrentar um mundo competitivo.

O estudo confirma que o crescimento brasileiro e a consequente busca por mais espaço no cenário internacional está sendo sutilmente realizada de acordo com a abordagem neorrealista de relações internacionais, embora o país ainda esteja lutando para conciliar a ambição de desempenhar um papel maior na arena mundial, com um declarado "destino" para fazê-lo de forma cooperativa, apoiado por atitudes pacíficas. 


\begin{abstract}
Brazil, Country of the Future is an expression created in 1941 to indicate the Brazilian potential to become a great power. After an extended postponement of this prediction, the period encompassing late 2000s and early 2010s finally saw Brazil released from its "Third World" label and growing consistently in geopolitical status.

Brazilian leadership - ratified by its constitution - presents a discourse of peace and cooperation towards the dynamics of the international system. Structural realism, however, predicts the country's international posture to be guided primarily on power and on practical and material matters, following its ascension to the great powers "club".

This work aims to evaluate in what extent Brazilian growth in stature in the international system is being performed according to the neorealist theory. In order to accomplish this goal, neorealism's main concepts are depicted and aggregated in a representation of its main variables in a causal chain. This framework is then opposed to Brazil's international posture in three phases: first, we confirm changing in Brazil's relative power, which is responsible to activate the process; then, we evaluate the intervening factors in the causal chain, namely, Brazil's domestic environment, the perceived threats to its security and Brazil's main goals in the international system; finally, we verify whether the intervening variables actuated to develop a revisionist posture in Brazil's foreign affairs.

Proceeding in the causal chain, we assess whether there is a noticeable effort for strengthening Brazil's military capacity and external alliances as evidences that the country is in fact starting to "emulate" great power's behavior to face a competitive world.

The study confirms that Brazilian growth and consequent pursuit of more space in the international arena is being subtly performed according to the neorealist approach to international politics, although the country is still struggling to conciliate the ambition to play a larger role in the world arena, with a declared "destiny" to do it in a cooperative way, supported by peaceful attitudes.
\end{abstract}

Keywords: neorealism, neoclassical realism, event data, Brazil's rise, military capacity, relative power, autonomy, pink tide. 


\section{LIST OF FIGURES}

Figure 1: Change in the Structure of the International System - Neorealism............27

Figure 2: Mechanism of Balancing - Neorealism ..............................................29

Figure 3: Change in the Structure of the International System - Proposed ...............33

Figure 4: Example of an Event Codification by GDELT ......................................... 38

Figure 5: State Power Measurement Equations ……………............................... 43

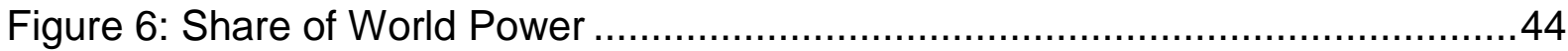

Figure 7: Brazilian World Position - GDP ....................................................... 46

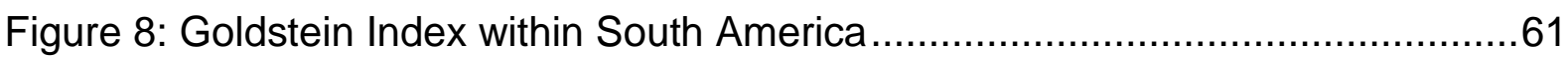

Figure 9: Intensity of Conflict Interactions within South America - 1980-2008 ...........62

Figure 10: Left-right political spectrum in Latin America - 2014 …..........................66

Figure 11: Distribution of Brazilian Military Expenses.......................................... 74

Figure 12: Comparative Brazilian-Chinese Military Expenditures.............................75

Figure 13: Comparative Brazilian-Chinese-American Military Expenditure ................75

Figure 14: South American Countries Ranked by Military Power (2014) ...................76

Figure 15: World States Ranked by Military Power (2014) ....................................77

Figure 16: Brazilian Military Expenditures (US \$m) ……................................... 78

Figure 17: Brazilian Military Expenditures (Share of GDP) ...................................78

Figure 18: Walt's Causal Chain for Formation of Alliance ..................................... 82 
TABLE OF CONTENTS

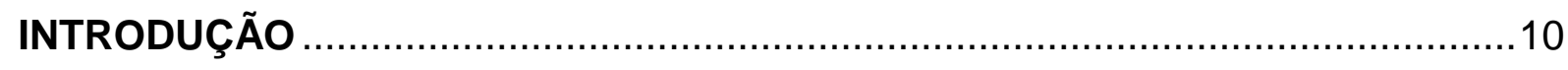

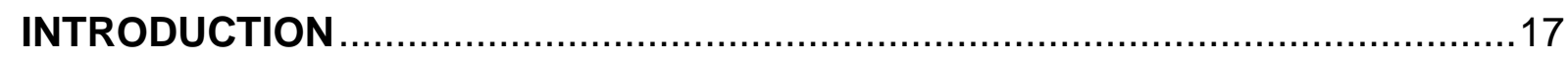

1. THEORETICAL FRAMEWORK AND ANALYTICAL TOOLS ......................23

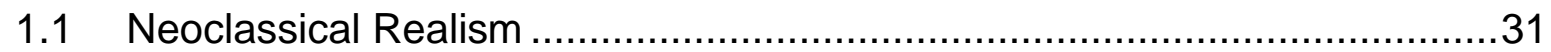

1.2 Main Line of Action - Process Tracing ................................................. 35

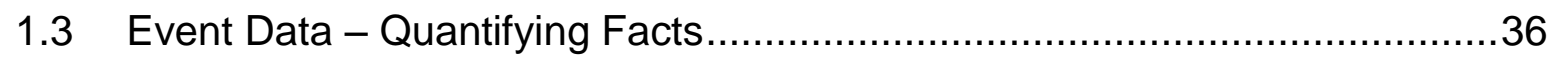

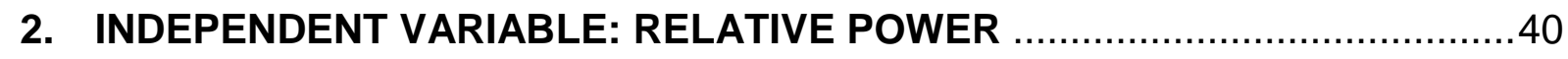

3. INTERVENING VARIABLE: BRAZIL'S MAIN GOAL - AUTONOMY .............48

4. INTERVENING VARIABLE: THREATS PERCEIVED BY BRAZILIAN STATE 55

5. INTERVENING VARIABLE: DOMESTIC FACTORS ..............................64

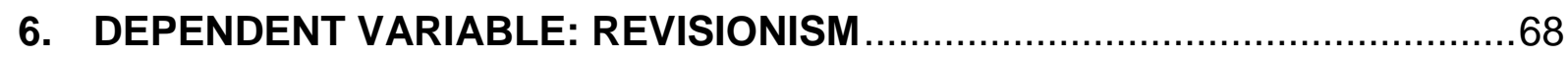

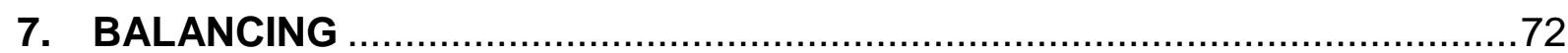

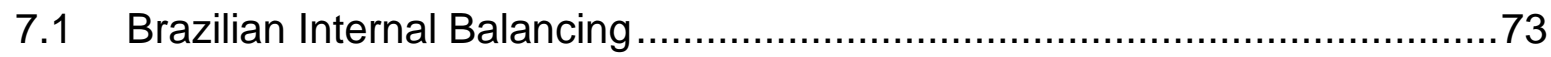

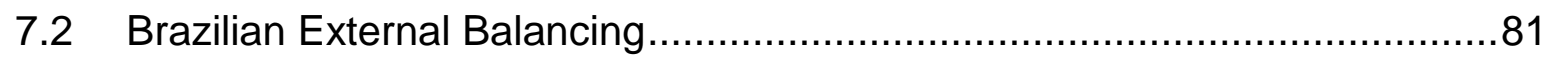

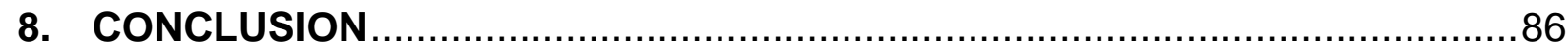

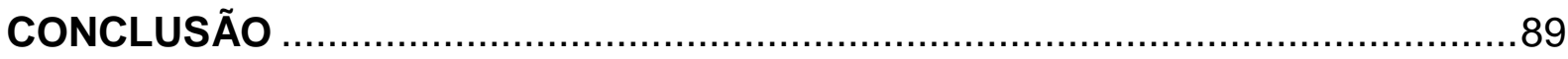

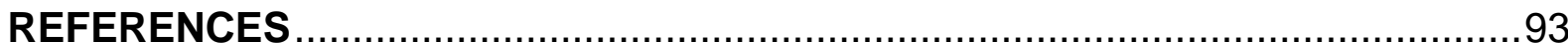




\section{INTRODUÇÃO}

Brasil, País do Futuro, lançado em 1941, possui, provavelmente, o único título de obra que foi transformado em epíteto nacional ${ }^{1}$. Na introdução do livro, o escritor e jornalista austríaco Stefan Zweig, afirma que antes de sua primeira visita ao Brasil, ele imaginou o país como "uma república como qualquer outra na América do Sul, com clima quente, insalubre, com condições políticas de agitação e finanças arruinadas." Depois de passar 12 dias visitando o país, no entanto, Zweig escreveu um livro onde ele retrata o Brasil como uma nação admirável e gloriosa, garantindo que o país foi, sem dúvida, destinado a ser um dos principais sustentadores do desenvolvimento mundial².

O prognóstico de Zweig veio atender a uma almejada - e constantemente adiada - aspiração brasileira. Desde os primeiros anos do século XX, o Brasil alimenta a ambição de ser reconhecido como um país independente e autônomo, convicto de que deve assumir seu papel "natural" de ator fundamental na política mundial. O desejo brasileiro de influenciar as regras e regimes internacionais e de ser considerado um grande ator no sistema, tem sido exercido, principalmente, em termos de soft power ${ }^{3}$, uma vez que o país tem sistematicamente desdenhado o desenvolvimento de hard power, especialmente de potencial militar ${ }^{4}$.

A sua localização em um ambiente regional relativamente pacífico, a adiantada consolidação de suas demandas territoriais e disputas fronteiriças, a posse de outros atributos de poder clássicos, como território e população, e sua consequente posição como uma potência status quo dentro da América do Sul, suportam conjuntamente suas aspirações.

Após um prolongado período sem que a previsão de Zweig fosse realizada, "país do futuro - e sempre será" começou a soar menos como piada e mais como uma promessa sendo cumprida.

Nos últimos 10 anos, o Brasil consolidou seu papel como uma superpotência

\footnotetext{
${ }_{1}^{1}$ Alberto Dines, Morte no paraíso, a tragédia de Stefan Zweig (São Paulo: Rocco, 2013).

2 Stefan Zweig, Brasil, País do Futuro (Rio de Janeiro: eBooks Brasil, 1941), pp. 12-13.

3 Joseph Nye define soft power como sendo "a habilidade de afetar outros por intermédio da cooptação para o enquadramento de agenda, persuasão, e provocação de atração positiva, a fim de se obter os resultados desejados". Hard power é entendido como sendo o uso de força, de pagamento e a definição de agendas com base nesses usos (The Future of Power, 2010, pp. 20-21).

${ }^{4}$ Maria Regina Soares de Lima and Mônica Hirst, "Brazil as an Intermediate State and Regional Power: Action, Choice and Responsibilities," International Affairs 82, no. 1 (Jan. 2006): p. 21.
} 
agrícola, descobriu enormes reservas de petróleo no Atlântico, pagou suas dívidas com o Fundo Monetário Internacional (FMI) e desenvolveu uma diplomacia mais assertiva. Em 2011, o país se tornou a sexta maior economia mundial, superando o Império Britânico 5 .

Com a confiança renovada, o Brasil começou a romper com a imagem estereotipada que era visto, de ser apenas o país do futebol e do samba.

"Quem pode imaginar hoje resolver os problemas do mundo sem a China, a Índia e, claro, o Brasil?" questionou o presidente francês Nicolas Sarkozy, em $2008^{6}$. De fato, a comunidade internacional parece reconhecer a nova estatura geopolítica brasileira. Pelo menos, isso é o que é expressado. O presidente americano Barack Obama, discursando durante a sua visita ao Brasil, em 2011, declarou:

"Por muito tempo, o Brasil era uma nação cheia de potencial, mas contida pela política, tanto interna quanto no exterior. Por muito tempo, vocês foram chamados de um país do futuro, e lhes foi dito para esperar por um dia melhor que estava sempre logo após a esquina. Meus amigos, esse dia finalmente chegou. E este não é mais um país do futuro. O povo do Brasil deve saber que o futuro chegou. Ele está aqui, agora."7

Apesar desta declaração lisonjeadora, o país pretende moldar seu futuro a sua maneira, e não de acordo com o "Consenso de Washington" 8 ou qualquer outro plano de ação externa.

O fato é que o Brasil está crescendo em status geopolítico e está ansioso para se tornar maior. Deixando para trás as denominações de "Terceiro Mundo" ou "NãoAlinhado", o país busca assumir o seu lugar no sistema internacional e acredita que possui uma verve pacífica que deve distingui-lo nessa arena. Nas palavras de Antonio Patriota, Ministro das Relações Exteriores brasileiro (2011-2013), o Brasil "é comprometido com a não-proliferação nuclear, com o uso da energia nuclear para fins pacíficos e estamos cercados por países com os quais as relações são exclusivamente benignas de cooperação, positivas. Isso define, de certa forma, o que

\footnotetext{
${ }^{5}$ A partir de 2012, o Reino Unido recobrou sua posição e o Brasil se manteve em sétimo lugar.

6 Jean-Baptiste Garat, "UE-Brésil: Sarkozy veut un partenariat renforcé," Le Figaro - Fr, Dec. 2008.

${ }^{7}$ Barack Obama, "Remarks by the President to the People of Brazil in Rio de Janeiro, Brazil," The White House, Mar. 20, 2011.Traduzido pelo autor.

8 O termo Consenso de Washington fui cunhado em 1989 para se referir a um conjunto de 10 específicas prescrições de política econômica que deveriam constituir o pacote de reformas "padrão" promovido por Washington para países em desenvolvimentos arruinados por crises - baseado $\mathrm{m}$ instituições como o Fundo Monetário Internacional (FMI), Banco Mundial, e o Departamento de Tesouro Americano.
} 
nós somos."

Entretanto, de acordo com a teoria de relações internacionais prevalecente, esta honrosa e altruísta abordagem do sistema mundial pode não ser viável. Kenneth Waltz, em Teoria de Política Internacional, publicado em 1979, buscou construir um arcabouço teórico que explicasse a repetição de padrões de comportamento e de interações entre estados no sistema internacional. Seu livro é considerado a obra seminal para a teoria neorrealista, uma das abordagens mais importantes para a disciplina de Relações Internacionais.

Waltz postula que, uma vez que não existe no sistema internacional um poder abrangente que possa impor regras globais ou punir o mau comportamento, esse se torna um ambiente de competição. Neste ambiente, é possível prever que os estados exibirão características comuns a competidores, ou seja, que eles tendem a se acomodar às regras do jogo da política internacional, mesmo quando a sua ideologia ou política interna ditarem que façam o contrário ${ }^{10}$. Em outras palavras, os países vão imitar uns aos outros e se "socializar" em seu sistema. Se um estado funciona relativamente bem, os outros vão imitá-lo, ou correrão o risco de ficar pelo caminho ${ }^{11}$.

O neorrealismo combina esse pressuposto com o conceito de distribuição de poder entre as nações. Waltz explica que capacidades ou poder variam significativamente entre as nações. Os estados, embora funcionalmente indiferenciados, são "distintamente posicionados em função de seu poder"12.

A combinação destes conceitos é representada pela imagem da política internacional como sendo uma "mesa de bilhar", composta por bolas cujas propriedades (forma, o material de que são feitas, etc.) são essencialmente as mesmas. As dimensões das esferas, no entanto, variam significativamente. $\mathrm{Na}$ famosa mesa de bilhar, as menores bolas tendem a se reunir pelos cantos, onde eles relativamente permanecem de lado. As maiores bolas, por outro lado, circulam por toda a mesa, muitas vezes interferindo nas bolas menores, algumas vezes atingindoas, às vezes batê-los mais, dominando o jogo e determinando como ele está sendo

\footnotetext{
${ }^{9}$ Antonio de Aguiar Patriota, "Discurso de Boas-Vindas," (discurso para o seminário: A América do Sul e a Integração Regional, Fundação Alexandre de Gusmão, Rio de Janeiro, 2011).

10 Kenneth Waltz, Theory of International Politics (Reading, MA: Addison-Wesley Pub. Co., 1979), p. 107.

11 lbid., p. 118.

12 lbid., p. 97.
} 
jogado $^{13}$. Se o Brasil está se tornando uma "grande bola", isto é, existe uma mudança de poder relativo no sistema internacional que favorece o Brasil, deve-se perceber uma mudança no comportamento do país. Não em direção à paz e cooperação, mas no sentido da política de poder.

Stephen Walt ilustra esses conceitos abordando o fim da Guerra Fria. Após este período complexo nas relações internacionais, figuras importantes das questões políticas mundiais asseguraram que "o cínico cálculo da pura política de poder simplesmente não se adequa mais; ele não se adapta a uma nova era ${ }^{14 "}$. Walt observa que, contrariando essas perspectivas, os Estados Unidos nunca abandonaram essa "política de poder", e os presidentes americanos Bill Clinton, George W. Bush, e Barack Obama, todos enfatizaram a necessidade de preservar a posição dos EUA como o país mais poderoso do mundo. Eles entenderam que a sua capacidade de exercer uma "liderança global" dependia da primazia americana e, especialmente, da posição privilegiada dos Estados Unidos como única grande potência no hemisfério ocidental $^{15}$.

Walt defende que esta não é uma política isolada e exclusiva dos americanos e cita as políticas cada vez mais assertivas da China em relação a sua vizinhança imediata, a defesa resoluta da Rússia do que ela vê como interesse vital em seu "exterior próximo" (i.e., a Ucrânia), e as potências regionais como Índia, Turquia e Japão que estão tratando de questões geopolíticas tradicionais mais seriamente hoje.

Certamente, pode-se argumentar que o ambiente de segurança do Brasil não é tão ameaçador quanto aqueles enfrentados por esses países. No entanto, à medida que o Brasil se move para garantir seu papel como uma grande e influente potência mundial, suas ideias podem começar a colidir com as ideias de outros estados. Seus interesses podem começar a sobrepor-se aos interesses de outros. E, eventualmente, sua busca por espaço pode trazer algum receio de que o espaço de outro está sendo tomado. É neste ponto que a teoria neorrealista começa a trabalhar. De acordo com Waltz, "o entendimento da política internacional como um sistema requer concentração nos estados que fazem maior diferença", ou seja, as grandes

\footnotetext{
${ }^{13}$ Jo Jakobsen, "Neorealism in International Relations - Kenneth Waltz," Popular Social Science, (Nov. 2013).

${ }_{14}$ Walt cita o discurso do então governador Governor Bill Clinton em 02 Out. 1992, no estado de Milwaukee, Estados Unidos.

${ }^{15}$ Stephen Walt, "The Top 5 Foreign Policy Lessons of the Past 20 Years," Foreign Police, (Nov. 18, 2014).
} 
potências $^{16}$.

Não obstante, a Estratégia Nacional de Defesa do Brasil, ecoando as posições traçadas na Constituição do país, afirma que:

“O Brasil é pacífico por tradição e convicção. Ele conduz suas relações internacionais, entre outros pelos princípios constitucionais da não-intervenção, defesa da paz e solução pacífica dos conflitos. Seu caráter pacifista faz parte da identidade nacional e um valor que deve ser preservado pelo povo brasileiro ${ }^{17 "}$.

O presente trabalho tem como objetivo avaliar em que medida a ascensão do Brasil no sistema internacional está sendo realizada de acordo com a abordagem realista para as relações internacionais ${ }^{18}$. Apesar de o Brasil promover um discurso de paz e cooperação, o realismo prevê que o crescimento em sua estatura internacional vai levar a um comportamento cada vez mais assertivo no sentido de influenciar e de rever a ordem atual. Essas ações seriam ancoradas no reforço de sua capacidade interna e na construção de alianças externas a fim de garantir seus interesses - quer sejam eles de segurança, expansão, prestígio, etc.

A avaliação do comportamento brasileiro focará no período que engloba o final dos anos 2000 e início dos anos 2010, tendo em vista ter sido esse o período que viu o país libertado de seu rótulo de "Terceiro Mundo". Essa periodização é bastante necessária uma vez que sombras à ascensão brasileira começaram a surgir. $\mathrm{O}$ crescimento da economia brasileira foi reduzido de 7,5\% em 2010, para 2,7\% em 2011, e de $1 \%$ em 2012. No momento em que este trabalho está sendo preparado, o crescimento de seu Produto Interno Bruto é estimado em 0,2\%. Mais ainda, a ausência do Brasil em discussões internacionais estratégicas se acentua no governo da presidente Dilma Rousseff e pode prejudicar a posição do país na comunidade internacional ${ }^{19}$. Academicamente, podemos também avaliar esta perceptível mudança - e consequente redução do poder relativo - de forma pragmática, uma vez que ela pode fornecer a falseabilidade necessária a esse estudo, ou seja, a capacidade de demonstrar que o afastamento da cadeia causal explicitada pela teoria ocasionará um

\footnotetext{
${ }^{16}$ Waltz, Theory of International, p. 73.

17 Ministério da Defesa do Brasil, Estratégia Nacional de Defesa, Brasília, DF, 2008.

18 No decorrer deste trabalho, empregaremos os termos "realista" e "neorrealista" como sinônimos, a menos que explicitamente pontuada a diferença.

19 Ver, por exemplo, Alistair Burnett, "Is Brazil Losing Global Momentum?" Yale Global Online, May 6, 2014.
} 
resultado oposto.

A fim de atingir nosso objetivo, temos alguns passos a seguir. O principal guia teórico que nos conduzirá neste estudo é a obra de Waltz, Teoria da Política Internacional. O trabalho está dividido em oito seções, mais curtas do que capítulos regulares, entretanto mais adequadas para classificar e analisar separadamente nossas variáveis. Na primeira seção, identificaremos as variáveis básicas que, de acordo com Waltz, devem atuar em um mecanismo de mudança no arranjo do sistema internacional. A identificação dessas variáveis é importante para sistematização e oposição ao caso brasileiro. Ao longo da seção, acrescentaremos a contribuição de uma revisão contemporânea do pensamento neorrealista - o realismo neoclássico. Após agregar as ideias de realistas neoclássicos, as variáveis resultantes serão representadas em um diagrama para compor a estrutura teórica para nossa análise.

A variável independente, crescimento do poder relativo, iniciará o processo, que será influenciado por três variáveis intervenientes: principais objetivos do Estado, suas percepções para o sistema internacional, e seu contexto doméstico. A variável dependente, revisão ${ }^{20}$ da ordem internacional atual pela potência em ascensão, encerrará a cadeia causal. O primeiro capítulo apresentará ainda os métodos que serão utilizados para alcançar nosso objetivo.

Depois de estruturar nosso quadro realista, vamos contrapô-lo à realidade brasileira, buscando indicações de que o mecanismo está em andamento. Cada uma das cinco seções posteriores avaliará uma variável de nossa cadeia causal. A seção 2 irá confirmar uma mudança no poder relativo do Brasil, responsável por ativar o processo. As seções 3, 4 e 5 vão abranger os fatores intervenientes na progressão da cadeia causal, respectivamente, o ambiente doméstico brasileiro, a identificação das ameaças percebidas para sua segurança, e o reconhecimento dos principais objetivos do Brasil no sistema internacional.

A sexta seção verifica se as variáveis anteriores atuarem para 0 desenvolvimento de uma postura revisionista na política externa do Brasil. Finalmente, devemos esperar encontrar um esforço para o fortalecimento da capacidade militar brasileira e de alianças militares como evidências de que o país está de fato começando a "imitar" o comportamento das grandes potências para enfrentar um

\footnotetext{
${ }^{20}$ Estados revisionistas buscam "revisar" o Sistema internacional, isto é, alterar suas posições no sistema atual. Estados status quo procuram manter o arranjo do sistema internacional e tentam fazer com que outros estados se sintam mais seguros (Schweller, Neorealism's Status Quo Bias).
} 
mundo competitivo. Essa análise é apresentada na seção 7.

A seção 8 vai encerrar a análise e apresentar as conclusões do projeto.

Este trabalho não pretende ser um estudo exaustivo de todos os aspectos da política externa e das relações políticas do Brasil. Em função disso, há uma série de áreas que, ou são omitidas, ou tratadas apenas brevemente.

No entanto, temos um objetivo que é simples em sua concepção, mas que nos levará para o terreno fértil da teoria realista, a partir do qual buscaremos sumarizar e sistematizar suas questões mais amplas. Concomitantemente, nosso trabalho vai abordar uma variedade de aspectos no ambiente brasileiro de relações internacionais, desde a condução da política de segurança, até aspectos conjunturais de governo. Através deste duplo escopo, esperamos verdadeiramente contribuir para os estudos acadêmicos sobre as relações internacionais e sua aplicação teórica tendo o Brasil como principal ator. 


\section{INTRODUCTION}

Brazil, Country of the Future, launched in 1941, is probably the single book title that was turned into a national epithet ${ }^{21}$. In the introduction to his work, the Austrian writer and journalist Stefan Zweig, affirms that before his first visit to Brazil, he imagined the country as "a republic like any in South America, with hot weather, unhealthy, with political conditions of unrest and ruined finances." After spending twelve days visiting the country, however, Zweig wrote a book where he portrays Brazil as a glorious and portentous nation, ensuring that it was undoubtedly destined to be one of the major sustainer of world's development ${ }^{22}$.

Zweig's prognostication came to meet a longed - and continuously postponed - Brazilian aspiration. Since the early years of the twentieth century, Brazil cherishes the ambition to be recognized as an independent and autonomous country, in accordance with its belief that it should assume its "natural" role as a great country in world affairs. Brazil's desire to influence international rules and regimes and to be considered a major player has been exerted principally in terms of its soft power ${ }^{23}$, since it has consistently disdained the development of hard power, especially military potential ${ }^{24}$.

Its location in a relatively peaceful regional environment, the early settlement of its territorial demands and border disputes, the possession of other classical power attributes, such as territory and population, and its consequent position as a status quo power within South America conjointly support its aspirations.

After a prolonged time without Zweig's prediction being accomplished, "country of the future - and always will be" started to sound less of a joke and more like a promise being fulfilled.

In the last 10 years, Brazil consolidated its role as an agricultural superpower, discovered massive oil reserves in the Atlantic, paid its debts to the International Monetary Fund (IMF) and developed a more assertive diplomacy. In 2011 the country

\footnotetext{
${ }^{21}$ Alberto Dines, Morte no paraíso, a tragédia de Stefan Zweig (São Paulo: Rocco, 2013).

22 Stefan Zweig, Brasil, País do Futuro (Rio de Janeiro: eBooks Brasil, 1941), pp. 12-13.

${ }^{23}$ Joseph Nye defines soft power as "the ability to affect others through the co-optive means of framing the agenda, persuading, and eliciting positive attraction in order to obtain preferred outcomes". Hard power is understood as the use of force, payment, and some agenda-setting based on them (The Future of Power, 2010, pp. 20-21).

${ }^{24}$ Maria Regina Soares de Lima and Mônica Hirst, "Brazil as an Intermediate State and Regional Power: Action, Choice and Responsibilities," International Affairs 82, no. 1 (Jan. 2006): p. 21.
} 
became the sixth larger world economy, overcoming the English empire ${ }^{25}$.

With a newly found confidence, Brazil started to break through the stereotypical image when others often saw it as only being the land of football and samba ${ }^{26}$.

"Who can imagine today solving world problems without China, India and of course Brazil?" questioned French president Nicholas Zarkozy, in 200827. In fact, the international community seems to recognize Brazilian new geopolitical stature. At least, that is what is expressed. The American president Barack Obama, discoursing during his visit to Brazil in 2011, has declared:

"For so long, Brazil was a nation brimming with potential but held back by politics, both at home and abroad. For so long, you were called a country of the future, told to wait for a better day that was always just around the corner. Meus amigos, that day has finally come. And this is a country of the future no more. The people of Brazil should know that the future has arrived. It is here now."28 Despite this flattering declaration, the country plans to shape its future its own way, not according to the "Washington consensus" 29 or any other foreign action plan.

The fact is that Brazil is growing in geopolitical status and is eager to get bigger. Leaving behind the denominations of "Third-World" or "Non-Aligned", the country is looking to take its place in the international system and believes that it possess a peaceful verve that should distinguish it in this arena. In the words of Antonio Patriota, Brazilian Minister of Foreign Affairs (2011-2013), Brazil "is committed to nuclear non-proliferation, with the use of nuclear energy for peaceful purposes and we are surrounded by countries with which relations are exclusively benign cooperation, positive. This defines, in a way, what we are." 30

Nevertheless, according to the prevalent international relations theory, this honorable and altruist approach to the world system may not be feasible. Kenneth Waltz, in his manuscript Theory of International Politics, published in 1979, endeavored

\footnotetext{
25 From 2012, the United Kingdom recovered its position and Brazil kept the seventh place.

${ }^{26}$ Silvia Salek, "Brazil: No longer Country of the Future," BBC News, Mar. 06, 2012.

27 Jean-Baptiste Garat, "UE-Brésil: Sarkozy veut un partenariat renforcé," Le Figaro - Fr, Dec. 2008.

${ }^{28}$ Barack Obama, "Remarks by the President to the People of Brazil in Rio de Janeiro, Brazil," The White House, Mar. 20, 2011.

29 The term Washington Consensus was coined in 1989 to refer to a set of 10 relatively specific economic policy prescriptions that should constitute the "standard" reform package promoted for crisiswracked developing countries by Washington, D.C. - based in institutions such as the International Monetary Fund (IMF), World Bank, and the US Treasury Department.

${ }^{30}$ Antonio de Aguiar Patriota, "Welcoming Speech," (speech for seminar: A América do Sul e a Integração Regional, Fundação Alexandre de Gusmão, Rio de Janeiro, 2011).
} 
to construct a theoretical framework for explaining recurring patterns of state behavior and state interaction in the international system. His book is considered the seminal work to neorealism theory, one of the most important approaches to International Relations.

Waltz posits that, since the international system has no overarching power that can enforce global rules or punish bad behavior, it becomes a competitive realm. In this realm, one can predict that states will display characteristics common to competitors: namely, that they will tend to conform to the rules of the game of international politics even when their ideology or domestic politics calls for them to do otherwise ${ }^{31}$. In other words, countries will imitate each other and become socialized to their system. If a state performs relatively well, others will emulate them or run the risk of falling by the wayside ${ }^{32}$.

Neorealism combines this assumption to the concept of distribution of power among nations. Waltz explains that capabilities or power vary significantly between nations. States, though functionally undifferentiated, are "differently placed by their power"33.

The combination of these concepts is represented in the image of international politics as a "pool table" consisting of balls whose inherent properties (shape, the material they are made of, etc.) are essentially the same. The sizes of the balls, however, vary greatly. On the proverbial pool table, the smallest balls tend to congregate around the corners where they more or less remain aside. The largest balls, on the other hand, can be found roaming about the whole table, often interfering with the smaller balls, sometimes knocking them over, dominating the game and determining how it is being played out ${ }^{34}$. If Brazil is becoming a "big ball", i.e., there is a change in relative power in the international system favoring Brazil, one should perceive a change in the country's behavior. Not towards peace and cooperation, but towards power politics.

Stephen Walt illustrates these ideas overlooking the end of the Cold War. After this complex period in international relations, important figures in world political affairs

\footnotetext{
${ }^{31}$ Kenneth Waltz, Theory of International Politics (Reading, MA: Addison-Wesley Pub. Co., 1979), p. 107.

32 lbid., p. 118.

33 Ibid., p. 97.

${ }^{34}$ Jo Jakobsen, "Neorealism in International Relations - Kenneth Waltz," Popular Social Science, (Nov. 2013).
} 
asseverated that "the cynical calculus of pure power politics simply does not compute; it is ill-suited to a new era." 35 Walt acknowledges that, contradicting those prospects, the United States had never abandoned "power politics", and American presidents Bill Clinton, George W. Bush, and Barack Obama all emphasized the need to preserve the U.S. position as the world's most powerful country. They understood that their ability to exercise "global leadership" depended on U.S. primacy and especially America's privileged position as the only major power in the Western Hemisphere ${ }^{36}$.

Walt supports that this is not a solely and isolated American politics and cites China's increasingly assertive policies toward its immediate neighborhood, Russia's positive defense of what it sees as vital interests in its "near abroad" (e.g., Ukraine), and regional powers like India, Turkey and Japan that are taking traditional geopolitical concerns more seriously these days.

Certainly, we may argue that Brazil's security environment is not as threatening as those faced by these countries. Nevertheless, as Brazil moves to assure its role as a great and influencing power in the world, its ideas may start to collide with others' ideas. Its interests may start to overlap with other countries' interests. And eventually, its pursuing of space may bring some fear that other's space is being grabbed. This is the point where neorealist theory starts to work. According to Waltz, "concern with international politics as a system requires concentration on the states that make the most difference", i.e. great powers ${ }^{37}$.

Notwithstanding, Brazilian National Defense Strategy, echoing the positions traced in the country's Constitution, states that:

"Brazil is peaceful by tradition and conviction. It conducts its international relations, among others by the constitutional principles of nonintervention, defense of peace and peaceful solution of conflicts. Its pacifist character is part of the national identity and a value that should be preserved by the Brazilian people"38.

The present work aims to evaluate in what extent Brazilian growth in the international system is being performed according to the realist approach to

\footnotetext{
35 Walt cites a speech by then Governor Bill Clinton on Oct 2nd, 1992, in Milwaukee, United States.

${ }^{36}$ Stephen Walt, "The Top 5 Foreign Policy Lessons of the Past 20 Years," Foreign Police, (Nov. 18, 2014).

37 Waltz, Theory of International, p. 73.

38 Ministério da Defesa do Brasil, Estratégia Nacional de Defesa, Brasília, DF, 2008.
} 
international relations ${ }^{39}$. Although Brazil promotes a discourse of peacefulness and cooperation, realism predicts that the rising in its international stature will lead to an increasingly assertive behavior to influence and to revise the current order. Such actions would be anchored in the strengthening of its internal capacity and in the construction of external alliances to guarantee its interests - be they security, expansion, prestige, etc.

The assessment of Brazilian behavior will focus on the period encompassing late 2000 s and early 2010s, since this period saw Brazil released from its "Third World" label. This periodization is strongly necessary since shadows on Brazil's raise start to appear. Brazilian economy growth was reduced from $7,5 \%$ in 2010 , to $2,7 \%$ in 2011 , and $1 \%$ in 2012. By the time this work is been prepared, 2014 GDP growth is estimated in $0,2 \%$. Furthermore, the absence of Brazil in international strategic discussions is been accentuated in the government of President Dilma Rousseff and may harm the country's position in the international community ${ }^{40}$. Academically, we can look this perceived change - and consequent reduction in relative power - pragmatically, since it can provide the falsifiability necessary for this study, i.e., the ability to demonstrate that the diversion from the causal chain explained by the theory leads to an opposite result.

In order to accomplish our purpose, we have some steps to follow. The main theoretical guide that will lead us in this study is Waltz's manuscript, Theory of International Politics. The work is divided in eight sections, shorter than regular chapters, but more adequate to categorize and evaluate separately our variables. In section 1, we will identify the basic variables that, according to Waltz, should act in a mechanism of change in the arrangement of the international system. The identification of these variables is important to systematize and oppose the theory to the Brazilian case. Along the section, we will add the contribution of a contemporary revision of neorealist thought - the neoclassical realism. After aggregating the insights of neoclassical realists, the resulting variables will be represented in a diagram to compose the framework for our analysis.

The independent variable, growth in relative power, will trigger the process,

\footnotetext{
${ }^{39}$ Along this work, we will employ the words "realist" and "neorealist" as synonyms, unless otherwise stated.

${ }^{40}$ See, for instance, Alistair Burnett, "Is Brazil Losing Global Momentum?" Yale Global Online, May 6, 2014.
} 
which will be influenced by three intervening variables: the state's main goals, its perceptions of the international system and its domestic context. The dependent variable, revision ${ }^{41}$ of the current international order by the rising power, closes the causal chain. The first chapter will also present the methods that will be employed to attain our goal.

After structuring our realist framework, we will oppose it to Brazilian reality, looking for indications that the mechanism is in progress. The next five sections will, each one, assess a variable of our causal chain. Section 2 will confirm a change in Brazil's relative power, which is responsible to activate the process. Sections 3, 4 and 5 will encompass the factors intervening in the progression of the causal chain, respectively, Brazil's domestic environment, the perceived threats to its security and Brazil's main goals in the international system.

Section 6 verifies whether the previous variables actuated to develop a revisionist posture in Brazil's foreign affairs. Finally, we should expect to find an effort of strengthening Brazil's military capacity and external alliances as evidences that the country is in fact starting to "emulate" great powers' behavior to face a competitive world. This analysis is presented in section 7.

Section 8 will wrap up the analysis and present the conclusions of the project.

This work is not intended to be an exhaustive study of every aspect of Brazil's foreign affairs and political relations. Accordingly, there are a number of areas that are either omitted or treated only in brief.

Nevertheless, we have a goal that is simple in its statement, but that will lead us to the fertile realm of realist theory, from which we will seek to summarize and sketch out its broader aspects. Concurrently, our work will address a variety of facets in Brazilian international relations domain, from the conduction of security politics to the conjuncture aspects of government. Through this twofold scope, we truly expect to provide a contribution to the academic studies of international relations.

\footnotetext{
${ }^{41}$ Revisionist states seek to "revise" the international system, i.e. change their position in the current system. Status Quo states seek to maintain the international system and try to make other states feel more secure (Schweller, 1996).
} 


\section{THEORETICAL FRAMEWORK AND ANALYTICAL TOOLS}

In greater or lesser extension, discussions in international relations theory has been dominated by the debate between neorealists and their various critics, an undoubted indication of the penetration of the theory. Neorealism - or structural realism - is usually associated with Kenneth Waltz and his 1979 book Theory of International Politics.

As is the case with all theories, there are many events that neorealism fails to explain. In fact, most types of state behavior and state interaction cannot usefully be accounted for by Waltz's parsimonious theory ${ }^{42}$. However, much - but by no means all - of the criticism neorealism faces is really of a straw man character: neorealism is often faulted for failing to explain or predict events or behaviors that neorealists had never set out to explain or predict in the first place. But neorealists can easily, and with some justification, claim that their theory is almost always the natural and necessary starting point when the events or developments under study represent the "big" issues in international politics, like the U.S. invasion of Iraq, or the conflicts in Ukraine.

Despite the prominence of the theory, there is not a vast number of works committed to understand South American scenario employing the neorealist perspective. We can conjecture on two main reasons for this absence. First, there exists a perceived distance from the American-European axis, since realism as a school of thought, had developed in conjunction with the growth of strong states. Waltz explicitly states his great powers approach when he declares that "concern with international politics as a system requires concentration on the states that make the most difference (...) a general theory of international politics is necessarily based on the great powers" 43 .

A second explanation shall be found in the assumption, within South American Academia, that realism is not suitable for the continent's scenario. According to this understanding, unlike the U.S. action, South American security agenda opts for instruments not traditional (i.e. that comprises military expressions) to problems that are mainly observed as having a social nature. Realism is perceived as a theory created to reflect and reinforce American behavior in international relations through U.S. government funding to research institutions. According to this idea, the state's

\footnotetext{
42 Jakobsen, "Neorealism in International".

${ }^{43}$ Waltz, Theory of International, p. 73.
} 
meddling in academic matters had influenced the content of research papers to reinforce the reading of an international reality where insecurity and competition initiatives prevented cooperation. ${ }^{44}$

Nevertheless, under any consideration, realism is a very powerful theory. In fact, we believe it can spot some light over Brazilian dynamics of geopolitical growth.

Traditionally, Brazilian international politics reinforce an idea of cooperation and harmony, which may not be coherent with neorealist theories. Since Brazil is consolidated as the biggest power in a relatively peaceful region, it should require low effort to hold onto the politics presented in the declaration of Brazilian Minister of Foreign Affairs: "South America is composed by states for whom relations are exclusively benign and positive, states that seek exclusively the preservation of the continent as a space for cooperation, democracy, development and peace" ${ }^{45}$.

As the country moves more amply within great powers' domains, we should expect a change in its attitude. According to Waltz, the structure of the international system encourages certain actions and discourages others. And the structure is "defined not by all of the actors that flourish within them but by the major ones" 46 .

Since Brazil is reaching the status of major power, structural realism would predict the country's international posture to be guided by the paradigms of Realpolitik. This set of policies or diplomacy encompasses a "prescriptive guideline" to policymakers, based primarily on power and on practical and material factors and considerations, rather than explicit ideological notions, moral or ethical premises.

Although we may agree with Professor Stephen Walt when he posits that "no single approach can capture all the complexity of contemporary world politics" 47 , realism is undoubtedly the most prolific theory among the studies of international relations. There are probably more books about its concepts and perspectives than those dedicated to all other paradigms.

Having developed its core arguments for the behavior of states since the 5th

\footnotetext{
44 To a more extended assessment on the description-prescription tension in American international relations scholarship, see Bruce Kuklick, Blind Oracles, Intellectuals and War from Kennan to Kissinger, 2013, p. 78-88, 138, 190. See also Grace Tanno, "A Contribuição da Escola de Copenhague aos Estudos de Segurança Internacional", Contexto Internacional 25, no. 1 (2003): 47-80, and Letícia Pinheiro, "Traídos pelo Desejo: um Ensaio sobre a Teoria e a Prática da Política Externa Brasileira Contemporânea," Contexto Internacional 22, no. 2 (2000).

${ }^{45}$ Patriota, Welcoming Speech.

46 Waltz, Theory of International, p. 93.

${ }^{47}$ Lecture on MIT Security Studies Program, Starr Forum: Whither US Grand Strategy, Oct. 09, 2014.
} 
century BC, with Thucydides' narration and assessment of the war between Sparta and Athens, realism was reformulated or reinterpreted on its main assumptions by a variety of scholars, and its concepts employed to assess a multiplicity of interactions between states from different times and different regions.

In 1956, the launch of Politic Among Nations, by Hans Morgenthau, laid the foundation of Classical Realism in International Relations theory. Morgenthau, a German political scientist that emigrated to the United States in the beginning of the World War II, theorized that the struggle for power, i.e. a position of dominance within a hierarchical system, is one of the elementary drivers of human behavior ${ }^{48}$. This drive is replicated at all levels of human social organization and culminates at the highest level in the struggle for power among nations.

Kenneth Waltz perceived as a sensitive assumption Morgenthau's idea of individual-level psychological attributes aggregating to the collective-level. In his initial contribution to the field of international relations, his 1959 book, Man, the State, and War, he classifies theories for the causes of conflicts into three categories, or levels of analysis: individual, that focus on the nature of particular statesmen and political leaders. State (or, society), that contends that wars are caused by the domestic makeup of states. And the international system, where its anarchic structure shapes state's behavior.

Anarchy is a key idea in realist thought. It simply means that there is no such thing as a world government; there is no higher authority above the main units that exist in the system - the states. Without a hierarchically superior, coercive power that can resolve disputes, enforce law, or order the system like there is in domestic politics $^{49}$, the world is transformed into a self-help realm, where autonomous states must always be prepared to fend for itself 50 .

In Theory of International Politics, Waltz seeks to reformulate the classical realist tradition of Morgenthau and elaborates the idea of an international system as a structure or a "set of constraining conditions" 51 . He restricts this set to three elements, defining a political structure in terms of its ordering principle, the distribution of the units' capabilities, and the functional differentiation of the units.

\footnotetext{
${ }^{48}$ Hans J. Morgenthau, Politics Among Nations, $2^{\text {nd }}$ ed. (New York: Alfred A. Knopf, 1956).

49 Robert Powell, "Anarchy in International Relations Theory: The Neorealist-Neoliberal Debate," International Organization, 1994: 313-344.

50 Jakobsen, "Neorealism in International".

51 Waltz, Theory of International, p. 73.
} 
According to Waltz's concepts, the pressures exerted by the anarchy structure of the international system explains the interaction of sovereign states, where their choices are limited and constrained by this structure ${ }^{52}$.

Structural constraints also explain why the methods are repeatedly used despite differences in the persons and states that use them. The close juxtaposition of states promotes their sameness through the advantages that arise when they conform to successful practices. It is this "sameness", an effect of the system, that is often attributed to the acceptance of so-called rules of state behavior.

Waltz understands that pacifists occasionally come to power. Yet, when in power, most of them quickly change their conducts. They can refuse to do so, and yet hope to survive, only if they rule countries little affected by the competition of states. The socialization of nonconformist states proceeds at a pace that is set by the extent of their involvement in the system ${ }^{53}$.

Since the theory depicts international politics as a competitive arrangement, one predicts more specifically that states will display characteristics common to competitors: namely, that they will imitate each other and become socialized to their system. States tend to conform to the rules of the game of international politics even when their ideology or domestic politics calls for them to do otherwise. Brazil discourse of a peaceful involvement in the international system is clearly challenged by these concepts.

Waltz illustrates his argument referring to the Bolsheviks in the early years of their power when they preached international revolution and flouted the conventions of diplomacy, as if saying "we will not be socialized to this system." ${ }^{4}$ In a competitive arena, however, refusal to play the political game may risk one's own destruction. The pressures of competition were rapidly felt and reflected in the Soviet Union's diplomacy.

A second defining principle concerning the structure of international politics is the distribution of capabilities across the units of the international system. Capabilities, or power, vary significantly between nations. States, though functionally undifferentiated, are "differently placed by their power" 55 . Variations in power yield

\footnotetext{
52 Waltz, Theory of International, pp. 99-100.

53 lbid., p. 128.

${ }^{54}$ Von Laue, Theodore H. Soviet diplomacy: G.V. Chicherin, People's Comissar for Foreign Affairs 19181930, 1963, p.235, quoted in Waltz, Theory of International, p. 128.

55 Ibid., p. 97.
} 
variations in the types and magnitude of structural constraints that states face, thereby making variation in how states behave (or should behave). Waltz explains that power should be estimated by comparing the capabilities of a number of units. Although capabilities are attributes of single elements, the distribution of capabilities are a system-wide concept. Traditions, habits, objectives, desires and forms of governments must be abstracted, and power kept as the only attribute of a state that shall be considered ${ }^{56}$.

Therefore, we can go back to the pool table analogy. A smaller ball does not want to be interfered or knocked over by the largest balls that dominate the game. However, to be capable of avoiding interference, an actor must be strong enough. This is a necessary feature because variations in the types and magnitude of structural constraints that states face are yielded by variations in power. States want influence more commensurate with what they perceive as their power to be. ${ }^{57}$

Waltz stresses the importance of power asserting that changing the distribution of capabilities across units is the only way to change structures. ${ }^{58}$

From this neorealist concept, we can represent a change in the arrangement of the international system, as follow.

Figure 1: Change within the Structure of the International System - Neorealism

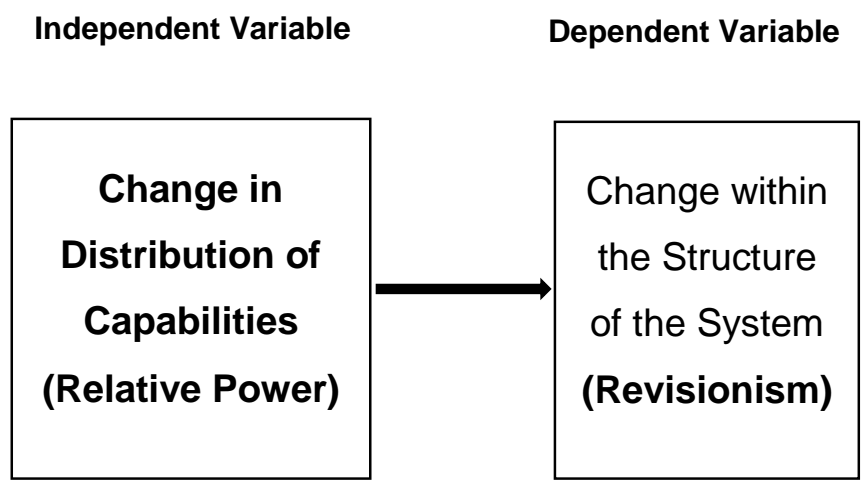

Source: Elaborated by the author.

Neorealism, however, posits that "the ultimate concern of states is not for

\footnotetext{
56 Waltz, Theory of International, p. 99.

${ }^{57}$ Barry Posen. Lecture, Nov. 2014.

58 Waltz, Theory of International, p. 108.
} 
power but for security"59. Waltz returns to Thucydides narrative of the Peleponnesian War: "What made war inevitable was the growth of Athenian power and the fear which this caused in Sparta. ${ }^{60 " ~ I n t e r n a t i o n a l l y, ~ t h e ~ f o r c e ~ o f ~ a ~ s t a t e ~ i s ~ e m p l o y e d ~ f o r ~ t h e ~ s a k e ~}$ of its own protection and advantage. States seek maximum security not maximum power. Waltz argues that Realpolitik indicates the methods by which foreign policy is conducted to attain security ${ }^{61}$.

The need for security in a self-help world (the will to "not be knocked over") would lead states to behave in ways that tend toward the creation of balances of power. In terms of strategies, states can choose between internal and external balancing, or some combination of the two. Internal balancing would request states to build up its economic and military capabilities and develop clever strategic moves. External balancing refers to efforts to strengthen one's position through alignment with one or more other states, i.e. the way of alliances.

Importantly, from the realist perspective, there is an automaticity to the balancing process. Waltz argues that "...balances are produced whether or not intended."62 As he succinctly puts it, "as nature abhors a vacuum, so international politics abhors unbalanced power."63

Balance of Power theory does not imply that states act with the intention of preserving the balance. They may or may not have this intention. It simply means that balancing is what results from all states acting rationally out of self-interest. Since balance of power theory is build up from the assumed motivations of states, the neorealist approach presents the following pattern to the state's motivations and the actions that correspond to them.

\footnotetext{
${ }^{59}$ Kenneth Waltz, "The Origins of War in Neorealist Theory," Journal of Interdisciplinary History 18, no. 4 (1988): p. 616.

${ }^{60}$ Cited in Paul Kennedy, The Rise and Fall of the Great Powers, ( New York: Vintage, 1987), p. 198.

${ }^{61}$ Morgenthau understands that power is the main concern of states. Waltz privileges security. However, offensive realists like John Mearsheimer (2001) take a different view; they maintain that it makes good strategic sense for states to gain as much power as possible and, if the circumstances are right, to pursue hegemony. The argument is not that conquest or domination is good in itself, but instead that having overwhelming power is the best way to ensure one's own survival.

62 Kenneth N. Waltz, "Evaluating Theories," American Political Science Review 91, ㄲo 4 (Dec. 1997): p. 914.

63 Kenneth N. Waltz, "Structural Realism after the Cold War," International Security 25, no 1 (2000): p. 28.
} 
Figure 2: Mechanism of Balancing - Neorealism

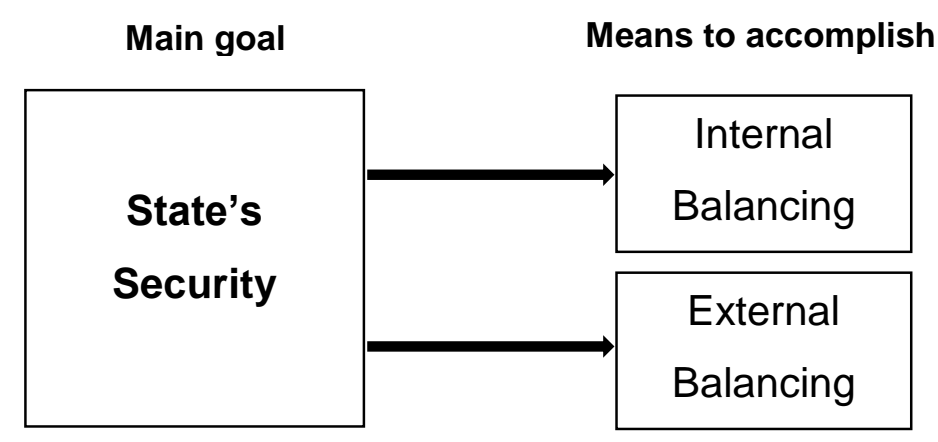

Source: Elaborated by the author.

A hasty view of the model may lead to a confusion concerning the concept of state's relative power and this idea of an induced balancing behavior. An example may clarify the subtle differences of these concepts. According to North Korea's state news agency ${ }^{64}$, military expenditures of the country for 2010 made up 15.8 percent of the state budget (an expenditure around 2.0 percent is normal to most countries). This obvious effort to increase internal balancing does not put North Korea between the great powers of the world. Attributes of power other than solely military mighty, improve the leverage capacity of a particular state. Brazilian geopolitical growth was supported mainly by the growth on its Gross Domestic Product (GDP), but housing a 200 million population in the fifth greatest territory of the world, with the possession of relatively abundant natural resources, are determinant to support its relative power. We will return to definitions of power in the next section of our work.

Nevertheless, when we attempt to visualize the general forces and patterns that move countries to change the international system, these models, built solely from neorealist theory, fails to account for many of the specific causal mechanisms at play in most cases of interstate conflicts. ${ }^{65}$

To advantage parsimony, Waltz had disregarded other factors that could

\footnotetext{
${ }^{64}$ Korean Central News Agency (KCNA), Pyongyang. 2010. Despite the report from North Korea's state news agency, most analyses of the country's defense sector estimate that defense spending constitutes between one-quarter and one-third of all government spending.

65 Jakobsen, "Neorealism in International".
} 
intervene in a variety of manners in the outcomes of the relations of states. Waltz's systemic theory emphasizes interstate relations as a realm apart from domestic politics and state's characteristics. Theories of international politics that include only unit-level attributes as causal variables, Waltz charges, are reductionists. By excluding unit-level attributes from his causal scheme, Waltz carefully resists the seductive "urge to reduce".

Heading the line of Waltz's critics, Richard Rosecrance observes that Waltz does not consider economics an "independent variable" in explaining the international system, for instance ${ }^{66}$. Although Waltz correctly regarded "economics" as one important constituent of the power capabilities of nations, the distribution of power is a system-level variable and the factors generating that distribution within states (economic growth) are unit-level and reductionist. The disinclination to deal with unitlevel influences or their dismissal is one primary basis of Rosecrance's criticism of neorealism.

Although Waltz's constantly defends his theory stressing that "international politics is not foreign policy" 67 , and that domestic variables might therefore "be relevant to a theory of foreign policy but not to a theory of international politics", if one wants to explain system change or transformation, more is needed.

Waltz may point out the direction where to look if we intend to structure a more comprehensive model:

"The theory explains why a certain similarity of behavior is expected from similarly situated states. The expected behavior is similar, not identical. To explain the expected differences in national responses, a theory would have to show how the different internal structures of states affect their external policies and actions." 68

We follow the idea contained in Waltz's statement to assent with Randall Schweller when he argues that structure alone cannot account for the outcomes and behaviors neorealism claims to explain 69 .

\footnotetext{
${ }^{66}$ Richard Rosecrance, "Reply to Waltz," International Organization, vol. 36, no. 3 (1982): p. 682.

67 Kenneth Waltz, "International Politics is not Foreign Policy," Security Studies, vol. 6, n. 1 (1996).

68 Waltz, Theory of International, p. 122.

${ }^{69}$ Randall L. Schweller, "Neorealism's Status Quo Bias: What Security Dilemma?" Security Studies 5, no. 3 (1996): p. 91.
} 
To make our framework more comprehensive, additional theoretical knowledge - the assistance of other theories about the dynamics of the international system - is required.

\subsection{Neoclassical Realism}

Discordances within neorealist thinking have led to the development of richer theories from within the realist approach. These theories attempt to better capture the complexity of state behavior. The neoclassical realist school, in particular, has generated useful frameworks that can be applied systematically to state security policies $^{70}$.

Neoclassical realism is a theory of international relations that is mostly perceived as a combination of classical realist and neorealist theories. Neoclassical realists explicitly incorporate both external and internal variables, updating and systematizing certain insights drawn from classical realist thought. Their main claim is that the impact of power capabilities on foreign policy is indirect and complex, because systemic pressures must be translated through intervening variables at the unit-state level ${ }^{71}$.

The theory holds that the actions of a state in the international system can be explained by three sets of variables. Systemic variables, which would focus on the distribution of power capabilities among states (i.e., relative power). Cognitive variables, such as the perception and misperception of systemic pressures, other states' intentions, or threats. And domestic variables, that focus on states' institutions, elites, and societal actors within society that affect decision-makers in foreign policy ${ }^{72}$.

Neoclassical realists argue that relative material power establishes the basic parameters of a country's foreign policy. They note, in Thucydides' formula, that 'the strong do what they can and the weak suffer what they must." Yet they point out that there is no immediate or perfect transmission belt linking material capabilities to foreign policy behavior. Foreign policy choices are made by actual political leaders and elites,

\footnotetext{
70 Viping Narang, Nuclear Strategy in the Modern Era, Regional Powers and International Conflict (Princeton: Princeton University Press, 2014), p. 28.

71 Gideon Rose, "Neoclassical Realism and Theories of Foreign Policy," World Politics 51, no. 1 (1998): p. 146.

${ }^{72}$ Fareed Zakaria, "Realism and Domestic Politics: A Review Essay," International Security 17, no. 1 (1992): p. 179.
} 
and so it is their perceptions of relative power that matter, not simply relative quantities of physical resources or forces in being ${ }^{73}$. This means that over the short to medium term states' foreign policies may not necessarily track objective material power closely or continuously. Furthermore, those leaders and elites do not always have complete freedom to extract and direct national resources as they might wish. Power analysis must therefore also examine the strength and structure of states relative to their societies, because these affect the proportion of national resources that can be allocated to foreign policy.

Therefore, systemic pressures may shape the broad contours and general direction of foreign policy without being strong or precise enough to determine the specific details of state behavior. Accordingly, Schweller posits that neorealism overlooks the importance of revisionist goals (nonsecurity expansion) as the driving behind most of its theoretical concepts. Schweller argues that structural realists have adopted a status quo (or security) bias in their explanations of international politics, but differences in state goals - whether states seek minimum power required for security or additional power for goals other than security - have to be accorded an equal consideration along with anarchy and the distribution of capabilities ${ }^{74}$. The primary objectives of states can be identified with security, power or even glory ${ }^{75}$.

As we had seen in this section, this approach is not accounted by Waltz in his theory. For Waltz, theory is not a statement about everything that is important in international-political life, but rather a necessarily slender explanatory construct ${ }^{76}$. For him, adding elements of practical importance would carry us back from a neorealist theory to a realist approach. Even though, realists do not deny that domestic politics influences foreign policy, but they contend that "the pressures of international competition weigh more heavily than ideological preferences or internal political pressures." 77 Waltz's highest concerns were directed to an analysis that focused exclusively at the unit, which he understood is bound to be misleading ${ }^{78}$.

\footnotetext{
${ }^{73}$ A complete portray of Germany pre WWI, Japan and Germany pre WWII should include Kaiser Wilhelm II, Hitler and the Japanese emperor.

74 Schweller, "Neorealism's Status Quo Bias", p. 91.

${ }^{75}$ An extensive study on the role of status in international politics can be found in T.V. Paul, Deborah Welch Larson and William C. Wohlforth. Status in World Politics (New York: Cambridge University Press, 2014).

${ }^{76}$ Kenneth N. Waltz, "Realist Thought and Neorealist Theory," Journal of International Affairs 44, n. 1 (Mar. 1990): 21.

77 Zakaria, "Realism and Domestic Politics", p. 180.

78 Kenneth N. Waltz, "The Origins of War in Neorealist Theory," Journal of Interdisciplinary History 18,
} 
Our model will incorporate these new insights to improve its representation of international relations' dynamics. Relative power remains the primary drive to induce a change within the system. However, neoclassical realists had enumerated other factors that intervene in a state's behavior: domestic context, misperceptions, uncertainty and the state's own interest. Therefore, to build our framework, we will categorize these variables as intervening variables, i.e. variables that explain a relation or provide a causal link between other variables. They will be the transmission belt linking material capabilities to foreign policy behavior.

After incorporating the neoclassical insights, we propose the following diagram to represent a change in the arrangement of the international system.

Figure 3: Change in the Structure of the International System - Proposed

Independent Variable Intervening Variables Dependent Variable

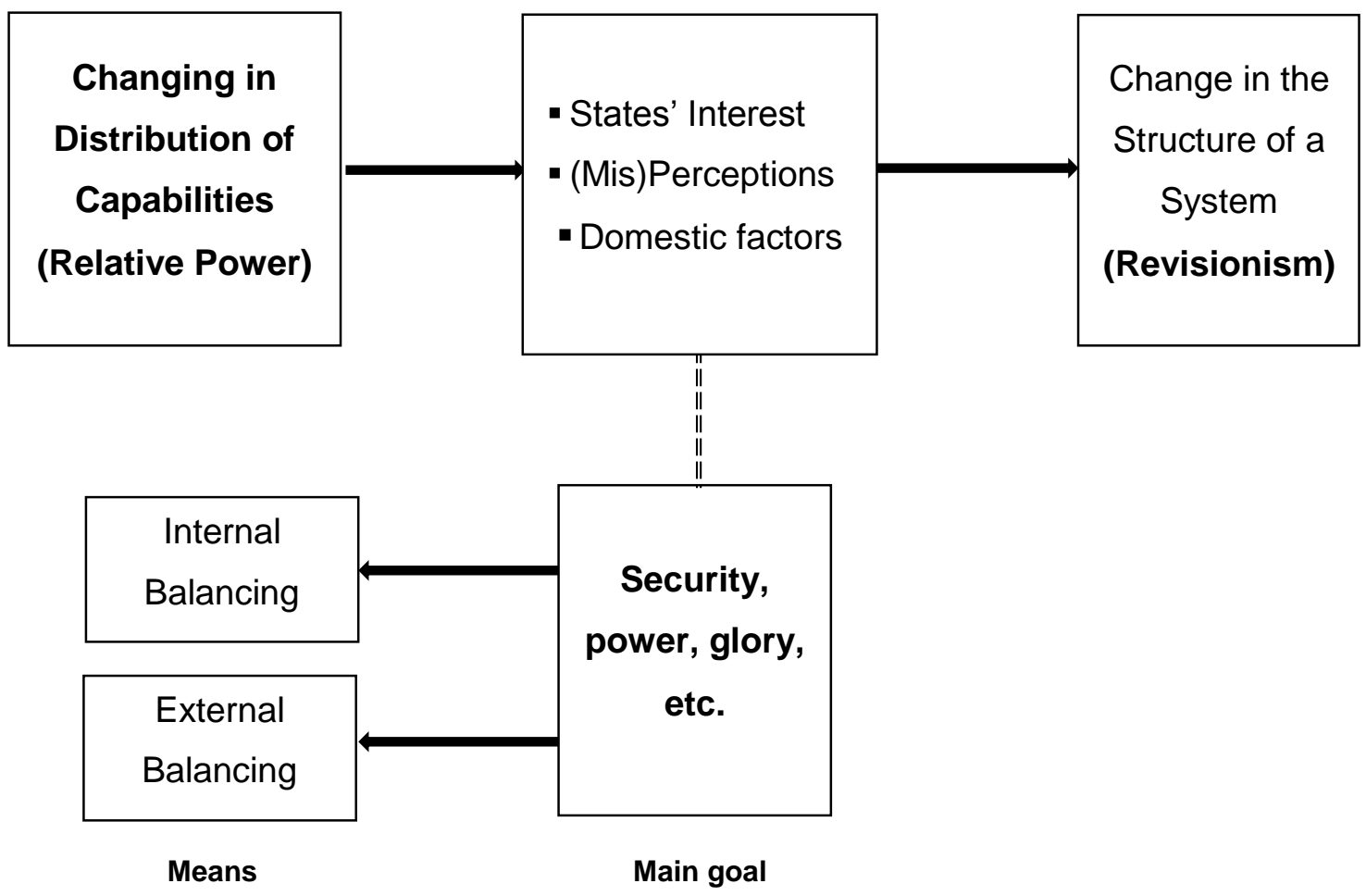

Source: Elaborated by the author. 
If we return to the example of North Korea, we will notice that the country spends a great part of its richness to strengthen its military might (as the country is considered a "pariah" in the international system, external balancing has mostly not been a conceivable option). This is the result of domestic variables, such as its perception of insecurity due to American presence in South Korea, and a domestic context of a totalitarian and militarist government, with an elaborate cult of personality around the "supreme leader".

The dynamic of the independent variable, which express change in relative power, is absent to North Korea, and the intervening variables are acting detached of the main process. A contrasting example can be presented when we oppose the model to the United States. As the greater power in the world, American main goal is obviously to remain the greater power. It is a status-quo state and has no intention to revise the international system. On the other hand, Brazil, that experienced a remarkable growth in its relative capacity, may trigger the whole process described, influenced by its main goals ${ }^{79}$, perceptions and by domestic factors.

We can now summarize this process involving the object of our analysis, the state of Brazil. Brazil's rise may lead to a change in the structure of the international system. The change, however, is under the possible effects of some variables. The first one would reflect Brazil's main goal, which may encompass not exclusively desire for security, but also eagerness for prestige or independence, desire to be powerful and even an ambition for more territory. Also intervening in the process, there will be Brazil's perceptions of constraints (source of insecurity) originated by the international system. Domestic factors within the country is the last aspect influencing its policies. Finally, realism predicts that structural constraints will lead Brazil toward sameness in policy and towards socialization to international norms for the sake of its objectives, namely Realpolitik and balancing behavior.

Therefore, in order to accomplish the objective of this study, we should verify whether Brazil is following the causal chain depicted above. Brazil's increase in relative power should be influenced by factors at the unit and at the state level to generate a revision of the system. These factors will determine initiatives of internal and external balancing. If this process is observed, we can confirm that the country, anxious to assume a more relevant role in the world, is being socialized by the system.

${ }^{79}$ These interests may range from security to power, prestige, territory, glory, etc. 
The next section will depict the methods that will be employed to support our work.

\subsection{Main Line of Action - Process Tracing}

The realist philosopher of science Andrew Sayer has stated that "what we would like $(. .$.$) is a knowledge of how the process works. Merely knowing that ' C$ ' has generally been followed by ' $E$ ' is not enough; we want to understand the continuous process by which 'C' produced 'E', if it did." 80

The empirical studies of international relations, both qualitative and quantitative, must struggle to overcome several obstacles that make theory testing challenging ${ }^{81}$. Political phenomena are difficult to measure and international relations scholars are unable to run controlled experiments, making it impossible to "replay" the same events several times with only one variable changed ${ }^{82}$. As a result, it is difficult to rule out competing explanations.

Sayer posits that a major impediment to the development of effective method in social science concerns causation. Causation is commonly perceived as a matter of regularities in relationships between events. Without models of regularities, we are left with allegedly inferior, ad hoc narratives ${ }^{83}$. Realism replaces the regularity model with one in which objects and social relations have causal powers which may or may not produce regularities, and which can be explained independently of them. This approach puts less weight on quantitative methods for discovering and assessing regularities and more on methods of establishing the qualitative nature of social objects and relations on which causal mechanisms depend.

An effective approach that encompass this concept was presented by social science methodologists and termed "process tracing". The method analyzes each case to verify whether the independent variable is affecting the dependent variable through the mechanisms predicted by the theories.

In political science, one of the earliest explicit definitions of process tracing was

\footnotetext{
${ }^{80}$ Andrew Sayer, Method in Social Science: A Realist Approach (London: Routledge, 1992).

81 Daryl Press, Calculating Credibility: How Leaders Assess Military (Ithaca: Cornell University Press, 2005).

82 Keohane, Robert O., Gary King and Sidney Verba, Designing Social Inquiry: Scientific Inference in Qualitative Research (Princeton: Princeton University Press, 1994), p. 72.

83 Sayer, 1992.
} 
provided by Alexander George and Timothy McKeown, who defined it as a method of within-case analysis to evaluate causal processes. According to these authors, this method does not solely rely on the comparison of variations across variables in each case, but also "investigates and explains the decision process by which various initial conditions are translated into outcomes." 84

More recently, Alexander George and Andrew Bennett defined process tracing as the "method that attempts to identify the intervening causal process - the causal chain and causal mechanism - between an independent variable (or variables) and the outcome of the dependent variable." 85

Bennett and George list different approaches to the general method of process tracing. This work will engage with the "process verification", which involves testing whether the observed process among variables in a case match those predicted by previously designated theories.

Our work will also benefit from another method - or technique - that will support our understanding of Brazilian perceived threats: event data.

\subsection{Event Data - Quantifying Facts}

Newspapers, magazines, wire services and other news media daily provide a large amount of data, gripping to International Relations scholars. Journalism is the source of most of the information that academics access on the international community, out of government officials ${ }^{86}$. This vast volume of reports covering international relations constitutes a huge and not completely explored treasure of information about the international system.

Nevertheless, as even simply reading all this information is physically impossible for individual researchers (let alone its interpretation), we need some summary of that data.

One of the manners used for summarization of the events within the scenario

\footnotetext{
${ }^{84}$ Alexander L. George and Timothy J. McKeown, "Case Studies and Theories of Organizational Decision Making," Advances in Information Processing in Organizations, 1985. p. 35.

${ }^{85}$ Andrew Bennett and L. Alexander George, Process Tracing in Case Study Research. MacArthur Foundation Workshop on Case Study Methods, 1997. p. 206.

${ }^{86}$ Gary King and Will Lowe. "An Automated Information Extraction Tool for International Conflict Data with Performance Performances Good as Human Coders: A Rare Events Evaluation Design." International Organization, 2003, p. 618.
} 
to be studied is the qualitative analysis of a small selection of available material. This method provides a very deep understanding of a relatively small portion of the documentation. Another approach can be performed by analyzing the synthesis of a much larger portion of the available material, taking into account only an essential outline of the fact. This is the approach used by "event data".

Event data are a formal method of measuring the phenomena that contribute to foreign policy perceptions. Event data are generated by examining thousands of newspaper reports on the day to day interactions of nation-states and assigning each reported interaction a numerical score or a categorical code. For example, if two countries sign a trade agreement, that interaction might be assigned a numerical score of +5 , whereas if the two countries broke off diplomatic relations, that would be assigned a numerical score of -8. Complex politics events between the analyzed actors are, therefore, "broken" in a sequence of basic building blocks (e.g., military commitments, threats, protests, diplomatic visits, demands, rewards, etc.) ${ }^{87}$. When these reports are averaged over time, they provide a rough indication of the level of cooperation and conflict between the two states ${ }^{88}$.

The standards presented by event data correspond to the narrative summaries of interactions found in historical sources, but unlike pure narratives, these data can be submitted to statistical analyzes or other quantitative technique. Consequently, event data is often used to study the results of foreign policy and the characteristics of the international context in which they occur.

To point out which are the perceived threats to Brazil, we recurred to a vast database of events generated from innumerous news agencies in the world. GDELT database - Global Data on Events, Location and Tone - was developed by Kalev Leetaru, Philip Schrodt and Patrick Brandt, and is currently a widely used platform in quantitative studies of international relations. Its sources comprehend Agence France Press (AFP), Associated Press Online, Associated Press, Africa News, Worldstream, BBC Monitoring, Christian Science Monitor, Facts on File, Foreign Broadcast Information Service, United Press International, Washington Post, New York Times,

\footnotetext{
${ }^{87}$ See Joshua S. Goldstein, "A Conflict-Cooperation Scale for WEIS Events Data" (1992); Philip A. Schrodt, "Event Data in Foreign Policy Analysis" (1993); and Tim Veen, "Event Data: A method for analysing political behaviour in the EU" (2008).

88 Philip A. Schrodt, "Event Data in Foreign Policy Analysis," in Foreign Policy Analysis: Continuity and Change in Its Second Generation, ed. Laura Neack, Patrick J. Haney and Jeanne A. K. Hey (New York: Prentice Hall, 1993), 1-28.
} 
Xinhua, and since 2002, Google News.

With a base containing about 200 million georeferenced data, GDELT has worldwide coverage from 1979, with daily update. The database is automatically encoded and made available free of charge by its developers.

GDELT offers another improvement to our study. It incorporates an index that "measures" in what extension an event between two actors is conflictive or cooperative. This indicator, called Goldstein index, incorporates values that range from -10 to +10 , with negative scores indicating a conflict and positive values indicating cooperation.

An example of an event codification is presented after the headlines of a July 31st, 2010 news, published by Agência Brasil89:

"Chavez mobilize troops on the Colombian borders."

The codification would break the headline in the following manner.

Figure 4: Example of an Event Codification by GDELT

\begin{tabular}{c|c|c|c|c}
\hline Date & Source & Goldstein & Target & Event \\
\hline 20100712 & VEN & $-7,6$ & COL & Mobilize or increase armed forces \\
\hline
\end{tabular}

Source: Elaborated by the author.

When a large volume of news for a region, actors and moment in time, is encoded, we have a consistent database for a more detailed analysis of the relations between the actors in the universe that we intend to study.

After describing the methods that will be used, our causal chain will be unfolded within the following guiding questions.

1. Independent Variable:

a. Is it possible to identify a growth in Brazilian capacity of action inbound the international system?

2. Intervening variables:

a. What are the main goals in Brazilian foreign politics? Security alone? Power?

${ }^{89}$ Agência Brasil is a Brazilian state News agency. 
Glory?

b. What are the constraints and threats to its security that Brazil perceives?

c. What are the domestic factors that could induce a revisionist attitude from Brazil?

3. Dependent variable:

a. Is Brazil in fact willing to revise the world order?

Subsequently, we will verify in what extent Brazil is engaging in balancing behavior to achieve its objectives in the international system:

a. Internal Balancing. An attempt to strengthen material capabilities is perceived?

b. External Balancing. Is Brazil looking for alliances?

This is the road map to direct our work. In the next sections, we will be attained to this guide to asses Brazil's growth under a realist perspective. 


\section{INDEPENDENT VARIABLE: RELATIVE POWER}

Waltz contends that "states are distinguished primarily by their greater or lesser capabilities for performing similar tasks. The structure of a system changes with changes in the distribution of capabilities across the system's units."90

Nevertheless, to identify a change in distribution of capabilities, a paramount feature in Waltz's theory, one requests a measure of these capabilities, a measurement of power. And how can we measure power? Waltz understands that this question must be answered in order to identify possible variations of structure ${ }^{91}$.

The simple definition of the term "power" is responsible for numerous discussions in academia.

British realist and writer E. H. Carr described international power as a combination of military power, economic power and power over opinion. He argued that, in politics, ignore power may be fatal. He cites 1914 Britain's government and 1848 Weimar Republic that had failed because many of its political actions opposed military power ${ }^{92}$.

Morgenthau, who understood power as the main drive of states, argues that "power may comprise anything that establishes and maintains the control of man over man.... from physical violence to the most subtle psychological ties by which one mind controls another"93. Morgenthau considered the armed forces as the most important material aspect of power, he believed that "power.... tends to be equated with material strength, especially of a military nature".

Notwithstanding, Waltz understands that states are not placed in the top rank because they excel in military, or economic or other capability, since they cannot be sectored and separately weighed. Their rank depends on how they score on all of the following items: size of population and territory, resource endowment, economic capability, military strength, political stability and competence. Historically, despite the difficulties, one finds general agreement about who the great powers of a period are, with occasional doubt about marginal cases. Nations are then said to be great powers even though they have only some of the previously required characteristics.

\footnotetext{
90 Waltz, Theory of International, p. 144.

91 lbid.,p. 129.

92 Edward H. Carr, The Twenty Years' Crisis, 1919-1939: An Introduction to the Study of International Relations ( New York: Harper Perennial, 1939), p. 130.

93 Morgenthau, Politics among Nations, p. 9.
} 
Waltz also acknowledges a non-conventional way a state gets the status of great power. It is when it is launched to that position by another country's policy toward it. He cites President Nixon, who, anxious to smooth the route to Peking, confirmed China's new rank in a statement and the headlines of various news stories before, during and after his visit to China in 1971. The episode keeps similarities with Barak Obama discourse in Rio de Janeiro, cited in the first section of this work.

American professor Joseph Nye understands that power always depends on context. The resources that produces power changed from gold in the sixteenth century, trade and finance in the seventeenth, large armies and populations in the eighteenth, to the primacy in the Industrial Revolution that Britain retained in the nineteenth century.

Nye argues that there is no unanimously accepted definition of power simply because the choice for a particular explanation reflects solely the interests and values of a certain group or individual ${ }^{94}$. Nye's definition depicts power as the ability to accomplish a goal, and within a social context, affect others to get the resources that one seeks ${ }^{95}$.

However, Nye's most well-known contribution to International Relations theories is related to the study of soft power. In the 21st Century, the concept of soft power has been emerging and many scholars have studied it as a behavior influence outcome in the post September 11 th period. ${ }^{96}$

Nye defines soft power as "the ability to affect others through the co-optive means of framing the agenda, persuading, and eliciting positive attraction in order to obtain preferred outcomes". ${ }^{97}$

A growing number of scholars defend that soft power is emerging and getting more influential in today's global information space where there is less hard power support. ${ }^{98}$ However, soft power and hard power literature is still much divided about the effectiveness and usefulness of such capabilities.

\footnotetext{
94 Joseph S. Nye, The Future of Power (New York: PublicAffairs, 2010), p. 18.

95 The theories of power and its methods of evaluation will not be discussed extensively in this work. For a summary table with an extensive bibliography, we recommend David A. Baldwin, "Power and International Relations" (2013) or Nathalie Toreão Serrão and Waldimir Pirró e Longo, "Avaliando o Poder Nacional" (2012).

96 Joseph S. Nye, "The Decline of America's Soft Power," Foreign Affairs (May 2004).

${ }^{97}$ Nye, The Future of Power, pp. 20-21.

98 Judit Trunkos, "What is Soft Power Capability and How Does It Impact Foreign Policy?" (PhD diss., University of South Carolina, 2013), p. 2.
} 
Skeptics of soft power argue that hard power must remain the essential instrument of policy, as soft power is unsuitable for policy directions and control. Soft power relies too much on the foreign countries' perceptions. Other scholars, such as Ferguson, states that there is nothing new about soft power, which was used to be called "imperialism"99. Ferguson understands that "soft power is merely the velvet glove concealing an iron hand."

In any case, the measurement of soft power is not an easy task. A variety of elements are considered, from technological innovation to a nations' patterns of aid, the spread of language learning, the diffusion of art, films, and other icons of culture. Tourism, emigration, alliance networks, and patterns of telephone and Internet communication would be other indicators ${ }^{100}$.

Our work understands national power simply as the capacity of a country to pursue strategic goals through purposeful action ${ }^{101}$. This view of national power suggests two distinct but related dimensions of capacity: an external dimension, which consists of a nation's capacity to affect the global environment through its economic, political, and military potential; and an internal dimension, which consists of a nation's capacity to transform the resources of its society into "actionable knowledge" that produces the best civilian and military technologies possible. ${ }^{102}$

Over the years, several analysts have developed mathematical equations that seek to quantify the power within the international system. Ray Cline provides a singular example. During the 1970s, Cline was the CIA chief analyst whose function was to advise political leaders in the US, about the balance of power between Americans and Soviets. In 1977, Cline published a book where he introduced an extract of the equation that he had created and used in his calculations to estimate power. After quantifying the necessary data, Cline concluded that the Soviet Union was twice more powerful than the United States ${ }^{103}$.

Since we can count on history to assist us, it is clear that Cline's equation did

\footnotetext{
${ }^{99}$ Niall Ferguson, Colossus: The Price of America's Empire (New York: Penguin Press. 2004), cited in Trunkos, What is Soft Power Capability, p. 3.

100 Gregory F. Treverton and Seth G. Jones, "Measuring National Power," (RAND National Security Research Division, 2005): p. 14.

101 lbid.

102 Ashley Tellis, Janice Bially, Christopher Layne, Melissa McPherson and Jerry Sollinger, Measuring National Power in the Postindustrial Age: Analyst's Handbook, (Santa Monica, CA: RAND, 2000), p. 4. 103 Richard G. Head, "Review of: World Power Assessment 1977: A Calculus of Strategic Drift by Ray S. Cline," Foreign Affairs (Apr. 1978).
} 
not provide a reliable estimate of power. However, the effort to create an index of power is permanent in empirical studies of international relations. In his article The Measure of National Power, Chin-Lung Chang presents the table below, in which he lists various state power measurement equations ${ }^{104}$.

Figure 5: Examples of State Power Measurement Equations

Singer and Small

$$
\text { Power }=\frac{(\text { tpop }+ \text { upop }+s p+f c+m b+s a f)}{6}, \text { where }
$$

tpop $=$ total population; $u p o p=$ urban population; $s p=$ steel production; $f c=$ fuel/coal production; $m b=$ military budget; $s a f=$ military personnel

$$
\text { Power }=N(L+P+I+M), \text { where } L=f_{1} \text { (territory, }
$$

German (1960)

Fucks (1965)

$$
\text { Power }=\frac{\left(E P^{1 / 3}\right)+\left(S P^{1 / 3}\right)}{2}, \text { where } E=\text { energy }
$$

production;

$$
P=\text { population; } S=\text { steel production }
$$

$$
\text { Power }=\frac{[\text { steel }+(\text { pop } \times \text { pol_stab })]}{2}, \text { where } \text { steel }=
$$

Beckman (1984) percentage of world steel production; $p o p=$ percentage of world population; pol_stab $=$ score for political stability

Organski and Kugler (1980); Kugler and Domke (1986)

$$
\begin{gathered}
\text { Power }=(\text { GNP } \times \text { Tax Effort })+(\text { Foreign Aid of Receipie } \\
* \text { Tax Effort }=\frac{\text { Re al tax ratio }}{\text { Tax capacity }}
\end{gathered}
$$

Source: Adapted from Chang, A Measure of National Power.

${ }^{104}$ Chin-Lung Chang, "A Measure of National Power" (Conference Paper - The National University of Malaysia, Feb. 2004). 
In his article, Chang proposes his own state power measurement index, different from the ones listed above ${ }^{105}$.

The CIA's Strategic Assessments Group (SAG) uses gross domestic product (GDP), population, defense spending, and a less precise factor that includes innovation in technology as the main metrics of world power.

SAG calculates power as a percentage of total global power: fourteen nations hold at least a 1 percent share. The United States holds about 20 percent of global power; the European Union (considered as a unified actor) and China, about 14 percent each. India holds about 9 percent. Brazil, South Korea, and Russia hold about 2 percent each ${ }^{106}$.

Figure 6: Share of World Power

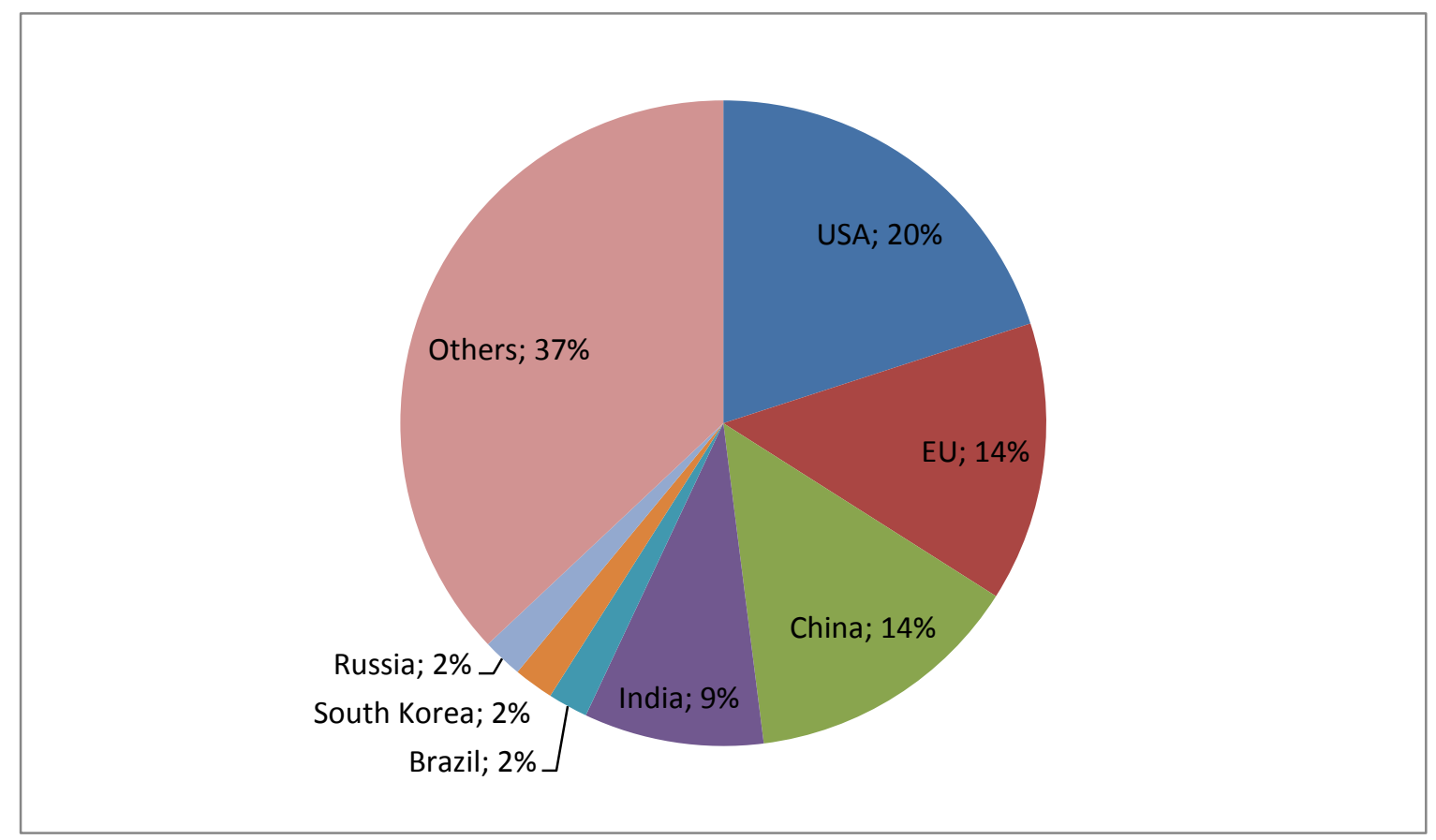

Source: Adapted from Treverton and Jones, Measuring National Power, p. 3.

When we analyze the intervening variables to foster Brazil's aspirations in the international system, its increase in relative economic and soft power from the 2000s seems to be a preponderant factor.

105 Chang, A Measure of National Power.

106 Treverton and Jones, Measuring National Power, p. 3. 
After decades of stop-and-start growth and political unrest, Brazil seems poised to fulfill its long-unrealized potential as a global player. In 2001, a Goldman Sachs report has categorized Brazil as an emergent power, defining the nation as a BRIC country, one of the four emerging markets - along with Russia, India and China - that would run the world economy by 2050.

The key features of Brazil's awakening are widely recognized: expanded exports, macroeconomic stability, growing foreign and domestic investment, booming consumer demand, ample dollar reserves, rapid growth, social assistance focused on the neediest, and democratic political cohesion. ${ }^{107}$

The diverse economy of the country is now founded on strong sectors in oil, mining, agriculture, and, more recently, biofuels, all of which have benefited from a combination of technological advancements and a stronger global demand for raw material. In the last decade, Brazil has recast itself as a global brand showing impressive result in poverty reducing in home to the world's fifth-largest land mass and about 200 million people.

Brazil seized the BRIC moniker and used it to amplify its leadership role on issues from climate change and food security to global trade. Its impressive social and economic gains and its diplomatic accomplishments, merged with the ambition, vision, and personal narratives of two of its recent presidents, Fernando Henrique Cardoso and Luís Inácio Lula da Silva.

In the end of 2007, a great reserve of oil and natural gas was found in the presalt layer extending for $800 \mathrm{~km}$ offshore between the Brazilian states of Espirito Santo and Santa Catarina ${ }^{108}$. The initial find in the Gulf of Santos was quickly followed by others, and by mid-2008 it was being hailed as "a new North Sea". Industry estimates of Brazilian oil reserves tripled, to 40 billion barrels, less than those of Iran, Iraq, Russia, Saudi Arabia, and the United States but equivalent to those of Nigeria and Venezuela. This placed Brazil in the ranks of the ten countries with the largest oil reserves.

In April 2008, another piece fell into place for Brazil when Wall Street ratings firm Standard \& Poor's upgraded Brazil's debt to "investment grade" - making Brazil the last of the BRIC nations to have its creditworthiness win that coveted seal of

107 Juan de Onis, "Brazil's Big Moment: A South American Giant Wakes Up," Foreign Affairs 87, no. 6 (2008): p. 110.

108 Paulo César Ribeiro Lima, Os Desafios, os Impactos e a Gestão da Exploração do Pré-Sal (Câmara dos Deputados, Brasil, Nov. 2008). 
approval. Brazilians rejoiced, pointing out that they had overhauled their economy even as the country's 23-year-old democracy was putting down ever-deeper roots. India is the only other comparably functional democracy among the BRICs ${ }^{109}$.

Figure 7: Brazilian World Position - GDP

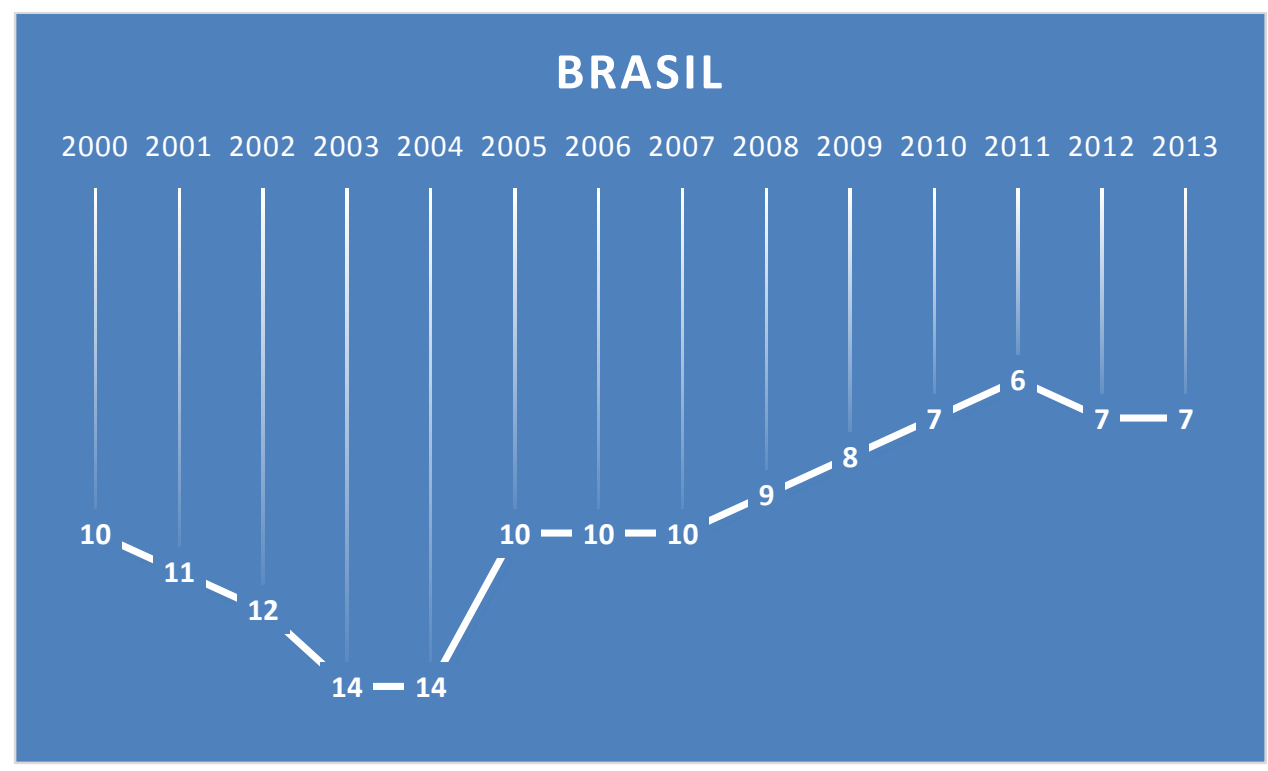

Source: Elaborated by the author.

Julia Sweig noticed that "an increasingly confident Brazil has undertaken an ambitious and far-flung foreign policy agenda"110. This confidence brought again to the political arena efforts to secure a seat on an expanded UN Security Council, to organize major and minor developing countries into a stronger coalition within the Doha trade talks, and to expand voting rights for itself and others at the World Bank and the International Monetary Fund.

Mr. da Silva, the union leader turned business-friendly president, hailed Brazilian achievements as proof that Brazil is "a serious country, with serious policies." The boast echoed - in reverse - a famous put-down, apocryphally attributed to Charles de Gaulle, that "Brazil is not a serious country."

Paul Kennedy, the great-power historian, argues that today's great powers consisting of the United States, China, Europe, Russia, Japan, India and Brazil, in his

\footnotetext{
109 Julia E. Sweig, "A New Global Player: Brazil's Far-Flung Agenda," Foreign Affairs 89, ㄲo 6 (2010): p. 174.

110 Ibid., p. 175.
} 
mind - are not the world's real "troublemakers." That is, none of them wishes to undo the basic nature of the international system. The real dangers to peace and stability, he says, lie in countries such as Syria, Iran, North Korea and Yemen ${ }^{111 .}$

Brazil surely do not intend to "put in danger peace and stability", but the country has long ambitioned to become a "big ball" in the international system. Nevertheless, a revisionist behavior pass through the influence of a group of variables. A little change in the disposition of Professor John Ikenberry's quote would alert that "structural constraints will determine what is possible to achieve, the preference function predicts what states will seek to achieve." 112 The sentence reflects the subject of our next section.

111 Paul Kennedy, "The Great Powers, Then and Now," The New York Times, Aug 13, 2013.

112 G. John Ikenberry, "The State and Strategies of International Adjustment," World Politics 39, no. 1 (1986): p. 65. 


\section{INTERVENING VARIABLE: BRAZIL'S MAIN GOAL - AUTONOMY}

"... It is necessary that Brazil make it clear to the United States and to the world the difference between antagonizing confrontation and confrontation for autonomy. The type of world that Brazil wants is a multipolar, in which the South American system will have autonomy vis-à-vis the American system." 113

Helio Jaguaribe, Brazilian sociologist, political scientist and writer.

Autonomy as a goal and as a guiding ideal is central to many of the most important understandings of Brazil's national project. Jaguararibe's quote is one among countless declarations that reflects the paramount significance that the concept has to Brazilian intellectuals, militaries, statesmen, in fact, to all Brazilian society.

Autonomy can be defined as the degree of effective independence that a state is able to attain. ${ }^{114}$ Andrew Hurrell notices that it is, by definition, a relative concept with all states finding themselves on a continuum between autonomy on the one hand and dependence on the other. As a relative concept, it can be distinguished from the concept of sovereignty which refers to a state's formal legal claim to independence irrespective of the degree to which it is able to implement that claim in practice ${ }^{115}$. Autonomy and dependence are here defined in terms of the objective of Brazilian state to possess the capacity to carry out its objectives in the international arena.

The Brazilian Political Scientist José Flávio Sombra Saraiva had traced the concept of autonomy in Brazil's Foreign Policy since the country's independence in 1822. ${ }^{116}$ In his work, Saraiva explains that, in certain historical periods, the concept of decision autonomy became jargon in Brazilian foreign policy. The idea had penetrated into various social and political layers in society, from the cabinets in the parliament to the streets. This is the case of the vaunted "Independent Foreign Policy" (Política Externa Independente - PEI), that marked the governments of Presidents Jânio Quadros and João Goulart (1961-1964). ${ }^{117}$

113 Quoted by Monica Hirst in "As Relações Brasil-Estados Unidos Desde Uma Perspectiva Multidimensional: Evolução Contemporânea, Complexidades Atuais e Perspectivas Para o Século XXI" (PhD diss., UFRGS, 2011).

${ }^{114}$ Andrew James Hurrell. The Quest for Autonomy: The Evolution of Brazil's Role in the International System, 1964 - 1985 (Brasília: Fundação Alexandre de Gusmão, 2013), p. 38.

115 lbid.

116 José Flávio Sombra Saraiva, "Autonomia na Inserção Internacional do Brasil: Um Caminho Histórico Próprio," Contexto Internacional, 36, no. 1 (2014).

117 lbid., p. 10. 
The domestic debate on Brazilian foreign policy had never questioned the importance or not of political autonomy. The discussions were centered mainly on the "degree" of this autonomy. The next section of this work will advance the influence the United States exert on Brazilian dynamics in the continent, but we may assert that it is strong enough to generate a debate between two approaches in the state's foreign policy: autonomy through participation - the maintenance of "degrees of freedom" with the expansion of economic interdependence - that postulates the search for a relationship of "friendship" with the United States. And a second approach, clearly stated in the tradition of "Independent Foreign Policy", which defends the idea that one should protect the sovereignty and "national interests", even creating potential conflicts with the United States. ${ }^{118}$

This main line of conduct, profoundly marked in the "nature" of the country, has not changed alongside democratic or authoritarian regimes.

Understanding the importance of this concept to Brazilian nation is central to comprehend the perceived security threats to Brazil. Wanderley Costa weighed as key element of concern for the Brazilian military, the possible interference of the main powers in its foreign policy, by means of controlling the technology flow and armament transfer for the country ${ }^{119}$. In the eighties, Brazil began to address that aspect as not a hypothesis, but as a real factor of pressure.

This judgment settled the speech reaffirming the Brazilian efforts to establish not only a national industry but also to support the efforts of nationalization of projects and components.

Saraiva, when providing an example to illustrate the importance of the concept of autonomy to Brazil, cites Admiral Álvaro Alberto Mota e Silva, who was representing the country at the United Nations Atomic Energy Commission in 1947 and had delineated the first proposal to establish a Brazilian nuclear program. Saraiva understands that Mota e Silva had a prominent role to assert the development of Brazilian nuclear potential, as a way to achieve autonomous scientific national progress.

The dominant role of autonomy discourse is, indeed, explicitly presented in the

\footnotetext{
118 Tullo Vigevani and Gabriel Cepaluni, "A Política Externa de Lula da Silva: a Estratégia da Autonomia pela Diversificação," Contexto Internacional 29, № 2 (2007): 273-335. p. 276.

119 Wanderley Messias Costa, "O Brasil e a América do Sul: cenários geopolíticos e os desafios da integração," Confins 7 (2009): p. 206.
} 
origins of Brazilian nuclear program and it is worth describing its main contours.

In 1972, product of an agreement with the United States, Brazil acquired a uranium power reactor, which should establish the first unit of the Central Nuclear Angra I. In 1975, looking for the development of technology within the country, Brazil has signed an agreement with Germany seeking the construction of eight nuclear power plants and also full transfer of technology in the nuclear fuel cycle and design, engineering and manufacturing of nuclear power plants components.

Within this agreement, the country invested to assemble an industrial structure, train technicians and acquire technology necessary for the construction of nuclear power plants, manufacturing elements fuel for power reactors and the production of uranium concentrate.

However, the 1970s witnessed a renewed concern with nuclear proliferation in the world, as India tested its nuclear device and numerous developing countries such as Argentina, Iraq, Libya, Pakistan, South Korea, and Taiwan made strides in the field of nuclear technology ${ }^{120}$.

American president Jimmy Carter, encouraged by Congress, made nuclear non-proliferation a top policy priority early in his Administration. Even before entering office, on November 1976, Carter gave a speech that set the tone for a very assertive stance on non-proliferation, specifically his intention to block the sale of fuel reprocessing plants from West Germany and France to Brazil and Pakistan, respectively.

Carter's vice-president Walter Mondale, in an official visit to FRG President Helmut Schmidt, reiterates his administration's viewpoint and requested that the German-Brazilian agreement be suspended temporarily for review ${ }^{121}$. This triggered a negative response from both the Brazilian and German Administration and led to an immediate souring of US-Brazil relations. Expressing Brazilian government reaction, an official of the ministry of mines and energy stated that the nuclear program

"will continue, at least to the extent it depends on us, against all internal and external pressures. The Germans know that we acted with seriousness in signing the agreement. We do not want the atomic bomb. We want to be

\footnotetext{
120 D. K. Nedal, "US Diplomatic Efforts Stalled Brazil's Nuclear Program in 1970," Nuclear Proliferation International History Project. Wilson Center, 2013. 121 lbid.
} 
independent, to construct our future, and to prevent (the effects of) any future world petroleum and energy crisis. Brazil will not give way." 122

The constraints imposed by external actors had a great bearing on technical and political aspects of Brazil's nuclear program. The construction of the Angra I nuclear plant contracted from the Germany company Westinghouse was severely delayed, as were the Angra II and Angra III plants stipulated in the agreement. US opposition to the transfer of German ultracentrifugation technology led to GermanBrazilian joint investment in the development of enrichment by jet nozzle, which ultimately was revealed as technically and economically impractical. Perhaps most important were the safeguards inserted in the agreement with Germany and the ensuing tripartite agreement with the IAEA, which together imposed severe limits to the range of research and experimentation that could be completed in Brazil with materials, technology and facilities associated with the German agreement.

At the end of the 70s, under international pressure to abandon the program, the understanding that the development of nuclear technology through cooperation agreements with other countries could not meet its aspirations, the reduction in demand for electricity, restrains to generate funds and the high costs of the program ${ }^{123}$, Brazil decided to reduce its nuclear ambitions.

Given the constraints imposed by major powers and international regimes, if Brazil wanted to make real progress on enrichment technology, the argument went, it would have to do so covertly and by cooperating with other countries on the margins of the NPT. This led to the creation of the Autonomous Nuclear program, also known as the parallel program, free of safeguards in 1978 and supposed to develop its own indigenous enrichment process.

According to the report of a former Minister of the Navy, in December 1981 the construction of the first ultracentrifuge was completed, through the work of seven engineers under the leadership of the navy officer Othon Luis Pinheiro da Silva, who had been studying nuclear energy in the United States from 1975 to 1978. The minister explained that "among the technicians who worked on its development, there was a group dedicated exclusively to the nationalization of components, since they could not

\footnotetext{
122 US National Archives and Records Administration, US Embassy Cable: Brazilian Public Reaction to US Nuclear Policies, Nov 19, 1976, Washington, DC: History and Public Policy Program Digital Archive. ${ }^{123}$ Estimates placed the cost of completing the original agreement at close to $\$ 40$ billion, over six times original projections.
} 
be purchased abroad, as a result of external pressures contrary to our project." ${ }^{124}$ In September 1982, a first isotopic uranium enrichment experience was successful using an entirely indigenous ultracentrifuge. Two years later, the operation of the first minicascade of ultracentrifuges is initiated. In September 1987, after the first centrifuges have "accumulated thousands of hours of operation", President José Sarney officially announced the Brazilian domain of uranium enrichment cycle, highlighting that "this is a fact of greater transcendence in the scientific history of the country" 125.

Although prestige is also a strong engine in Brazil's foreign affairs, it was not the primary driving force in its foreign policies. Brazil's desire to influence international rules and regimes can be understood principally in terms of the concept of autonomy. In 1985, a secret report of the General Secretariat of the National Security Council to the Brazilian President, where he presents the current development of the "autonomous program", is generous in evidences for this assertive:

"The right to use nuclear energy for peaceful purposes, to support our technological independence and as a perspective of progress for all of Latin America, constitutes a basic foundation of the National Nuclear Energy Policy." 126

The report mentions U.S. sanctions to the program that have created "all sorts of obstacles, initially of a technical nature and subsequently presenting overt political motives, with repercussions in the economic field"127.

Many governmental institutions were secretly assigned a specific nuclear project during the autonomous program. The Brazilian navy, ultimately responsible to develop nuclear technology, was in charge of the development of ultracentrifuge technology to power a dual-use nuclear reactor, suitable to propel a submarine and generate electricity for civilian consumers ${ }^{128}$.

For a number of reasons, the Brazilian nuclear submarine was never completed. This gridlocked project gained a renewed impulse by the year of 2008 . A

\footnotetext{
${ }^{124}$ Brazil, Congresso Nacional, Testimony of Admiral Almirante Maximiano da Fonseca, former Ministry of Navy, June 21, 1990, Brasilia, DF: Parliamentary Commission of Inquiry held to investigate the Nuclear Energy Autonomous Program.

125 José Sarney, "Speech: No Clube Dos Nove," Senado Federal. Brasilia. 04 Sept. 1987. Biblioteca Digital do Senado Federal. Web. 21 Jan. 2014.

126 US National Archives and Records Administration, US Embassy Cable: Brazilian Public Reaction to US Nuclear Policies.

127 Ibid.

${ }^{128}$ Brazil, National Security Council, Letter from Minister and Secretary-General of the National Security Council, Danilo Venturi to Brazilian President, Feb. 25, 1985, Brasilia, DF: Revision of the Concepts of the Autonomous Program.
} 
nuclear cooperation agreement was signed with France, which also included the joint development of four conventional submarines.

The new capabilities that will be aggregated to Brazilian military power strongly increase its range of action. Nevertheless, more than supporting security threats - as per protecting the recently discovered pre-salt oil reserves in the country - the Brazilian nuclear submarine may serve to other purposes.

A brief look in Brazilian president Dilma Rousseff's words in 2013, when inaugurating the facilities of the nuclear submarine, may show other directions for where to look:

"...this is the affirmation of the importance and pride we feel when we look there and see written, 'Made in Brazil'. The local content, the domestic content of what is produced here shows the strength of the Brazilian capacity. ${ }^{129 "}$

This pride for a national technologic accomplishment captured in this speech cannot be assessed exclusively within a security framework.

The Brazilian nuclear program is surrounded by controversy, engaging many different theories for why the Brazilian government would have started it in the first place. Impactful answers were offered, such as "because of an extreme military megalomania to create the bomb"130 or as a form to "serve the interests of the German private capital, which provided technology and equipment for the program"131. When we assess the nuclear program keeping perspective of the fundamental importance of the concept of autonomy to Brazil, we can understand how the program managed to progress, despite international sanctions, economic difficulties, a radical change in the political regime and the expected technical challenges.

The assertion of Brazil's nuclear autonomy had also been disclosed on 2010 Iran nuclear issue. On May 17 that year, in a joint declaration, Iran, Brazil, and Turkey announced they had reached an agreement on a fuel swap. IAEA director Mohamed Elbaradei considered the agreement a leap forward, particularly because it signaled the willingness of new players, Turkey and Brazil, to take an active role in resolving a diplomatic impasse ${ }^{132}$. Since Brazil had added a ban on nuclear weapons to its

129 Dilma Rousseff, "Discurso na Cerimônia de Inauguração da Unidade de Fabricação de Estruturas Metálicas - UFEM", Mar. 01, 2013.

130 "Sarney Arma Seu Ciclo," Revista Veja, no. 992, Sep. 1987.

131 Rafael Vaz da Motta Brandão, "O Negócio do Século: O Acordo de Cooperação Nuclear BrasilAlemanha" (Master diss., Universidade Federal Fluminense, 2008).

132 Mohamed ElBaradei, The Age of Deception: Nuclear Diplomacy in Treacherous Times (New York: Metropolitan Books, 2011). 
constitution, Brazilian decision makers understood they enjoyed credibility on this question. "I want for Iran the same thing that I want for Brazil, to use the development of nuclear energy for peaceful purposes," President Lula said. "If Iran is in agreement with this, then Iran will have the support of Brazil." 133

Although the episode can be attributed to Brazil's desire to demonstrate it could resolve international problems, and as an opportunity to challenge what it perceived to be an unjust and outdated world order ${ }^{134}$, the discourse of independence and self-government is clearly present. Autonomy is a very important drive, a preponderant goal in Brazil's international affairs.

The next section of our work will continue our study of the factors that affect Brazil's will to a change in the international system. If the country perceives it is being threated, the currently increase in its power would surely continue a process of revision of the system, but more important, would also initiate a balancing dynamic.

Our work will address this topic in the next pages.

${ }^{133}$ Cited in Trita Parsi, A Single Roll of the Dice: Obama's Diplomacy with Iran (New Haven: Yale University Press, 2013), p. 175. At the very next day, the P-5+1 announced that they had reached agreement on a fourth Security Council resolution to escalate sanctions on Iran for not bringing its enrichment program to a halt. American Secretary of State Hillary Clinton called the fuel swap deal with Turkey and Brazil a "transparent ploy" on Iran's part to avoid new sanctions.

134 Ibid., p. 176. 


\section{INTERVENING VARIABLE: THREATS PERCEIVED BY BRAZILIAN STATE}

Stephen Walt proposed four main factors that shall contribute to state's perception of threat: another state's aggregate power, its geography proximity, its offensive power and a perceived aggressive intentions ${ }^{135}$. Our study will briefly assess South American scenario as a whole, where Brazil is inserted, to verify the influence of these factors in Brazilian perception of threat.

Brazil has peacefully settled all of its unresolved territorial disputes with neighboring countries by the early period of the twentieth century. As a result, for over 100 years the country has considered itself a "geopolitically satisfied" country with its state-building process being the result of successful diplomatic negotiation rather than engagement in military disputes. ${ }^{136}$

In a broader view, relations among the South American nations during this century have been remarkably placid, to a degree unmatched in most other regions of the world. Regardless of enduring bilateral rivalries and several militarized interstate crises, South American countries have paradoxically avoided large-scale, intraregional war. In a period of 198 years (1816-2014), they waged four major wars in the nineteenth century, one in the first half of the twentieth century, and none since the end of the Chaco War in 1935..$^{137}$

Despite the general peaceful geographic framework, some territorial differences and the ambitions of its main countries - Brazil, Argentina and Venezuela - constituted causes of unrest within the subcontinent in the last century. The Cold War period, with the presence of dictatorships in Brazil, Argentina, Uruguay, Chile, Ecuador and Peru, built a quite distrustful geopolitical scenario, with countries massing troops on their borders in order to protect their territory for a possible invasion of the neighboring government (Peru and Ecuador), or with the objective of consolidating a sub-regional hegemony on the continent (Brazil and Argentina) ${ }^{138}$.

The rivalries started to weaken in the early 1990s, with the establishment of

\footnotetext{
135 Stephen Walt, The Origins of Alliances (Ithaca: Cornell University Press, 1987), p. 21.

${ }^{136}$ Lima and Hirst, "Brazil as an Intermediate State", p. 22.

${ }^{137}$ Felix E. Martín, "The Militarist Peace in South America, 1935-2003" (paper prepared for the 2004 Annual Meeting of the American Political Science Association, September 2004), p. 2.

138 Elói Martins Senhoras, O Conselho Sul-Americano de Defesa e as Percepções da Construção da Segurança Cooperativa no Complexo Regional da América do Sul. (Cartagena: Centro de Estudios Hemisféricos de Defensa, 2009).
} 
the democratization process in South America ${ }^{139}$. As part of this process, all countries decided to implement their respective Ministries of Defense and developed security policies that explicitly highlighted their overall objectives of foreign policy based on respect for international law and peaceful coexistence and cooperation.

Another key factor to stabilize the region was the strengthening of BrazilianArgentinian relations, which started in the eighties and converted into a fundamental move in terms of international politics and diplomacy. ${ }^{140}$ After the harmonization between the most prominent actors of the continent, regional integration gains increasingly importance. It is seen as a strategy to strengthen the presence of the South American countries in the world, giving them greater weight in the relations with the major centers of power, particularly with the United States.

Robert Cox echoes Waltz when he says that powerful actors are "causes" of change in the behavior of less powerful ones, and the structure of the system "causes" certain forms of behavior on the part of actors ${ }^{141}$. Within South America, the United States is certainly the main "cause".

Ever since the early nineteenth century, the United States has been stronger and richer than its Latin American neighbors. The first American initiative to exert leverage over the subcontinent dates from 1890, in the occasion of the first International Conference of American States. This conference originated the International Union of American Republics, which had the declared purpose of creating a political and economic unified space within the concept of Pan-Americanism, with the United States keeping a hegemonic role. ${ }^{142}$

The Second World War compelled the United States to renew their efforts to rise the control over the hemisphere through political and economic pressures on the countries of the region, aiming to dissolve German influence and to force South American states to contribute, if not actively, at least as raw materials suppliers. ${ }^{143}$ These efforts culminated in the signing in 1948 of the Rio Treaty, or Inter-American

\footnotetext{
139 Costa, "O Brasil e a América do Sul", p. 12.

140 Tullo Vigevani, Gustavo Favaron, Haroldo Ramanzini Júnior, and Rodrigo Correia, "O papel da integração regional para o Brasil: universalismo, soberania e percepção das elites," Revista Brasileira de Política Internacional 51, no. 1 (2008).

141 Robert W. Cox, "Social Forces, States and World Orders: Beyond International Relations Theory," in Neorealism and Its Critics, eds. Robert O. Keohane (New York: Columbia University Press, 1986), p. 242.

142 lbid., p. 5.

143 Ibid., p. 6.
} 
Treaty of Reciprocal Assistance, whose central principle is the declaration that an attack on one member is considered an attack against all.

The Cold War altered the basis of inter-American relations, elevating the concept of "national security" to the top of the U.S. agenda and turning Latin America (and other Third World areas) into both a battleground and a prize in the conflict between communism and capitalism. The doctrine of "containment" led the United States to extend and consolidate its political supremacy throughout the hemisphere. By the early 1950s, Washington laid down policy lines in accordance with the terms of this regime, and they persisted through the 1980s. ${ }^{144}$

Within that period, the United States applied diplomatic pressure, engaged in covert operations, and on several conspicuous occasions resorted to military intervention ${ }^{145}$. We can list some examples:

1946 - U.S. Army School of the Americas opens in Panama as a hemispherewide military academy. Its linchpin is the doctrine of National Security, by which the chief threat to a nation is internal subversion; this will be the guiding principle behind dictatorships in Brazil, Argentina, Uruguay, Chile, Central America, and elsewhere.

1954 - Alfredo Stroessner from Paraguay ousted Federico Chávez, becoming president after winning an election in which he was the sole candidate. Stroessner had the backing of the United States.

1961 - CIA-backed coup overthrows elected President J. M. Velasco Ibarra of Ecuador.

1964 - President João Goulart of Brazil is ousted by U.S.-supported military coup.

1966 - The first Argentinian dictatorship began with a coup that overthrowed the constitutional president, Arturo Illia.

1973 - In Chile, U.S.-supported military coup kills Salvador Allende and brings Augusto Pinochet to power.

\footnotetext{
144 Peter H. Smith, Talons of the Eagle - Dynamics of U.S. Latin American Relations (New York: Oxford University Press, 2000).

145 lbid., p. 190.
} 
1973 - Military takes power in Uruguay, supported by U.S. The subsequent repression reportedly features the world's highest percentage of the population imprisoned for political reasons.

1976 - Again in Argentina, a military coup ousted the government of Isabel Martinez de Peron. Upon seizing power, the generals claimed to have brought back the country from the brink of "dissolution and anarchy" and, like their Brazilian and Chilean counterparts, vowed to combat "subversion".

The interventions in South American domestic political process were not the exclusive instrument the United States employed in accordance to its doctrine of containment. Washington also provided inspiration, financing and technical assistance for repression, facilitating greater coordination among intelligence services in the region ${ }^{146}$.

In May 2011, during the opening conference of the Center for Strategic Studies of Union of South American Nations, ministers and experts invested directly and indirectly against the U.S. security doctrines and the European powers, defining a consensus that the end of natural resources, population growth, climate change and the policy of military "extraterritorial" actions from the United States and its European allies are some of the "threats" prowling South America. ${ }^{147}$

Some movements that were perceived as unequivocal threats to South American security are the reactivation of the Southern Command in Miami ${ }^{148}$ and its Fourth Fleet ${ }^{149}$, the search for the establishment of a common market of the Americas under U.S. leadership (FTAA - Free Trade Area of the Americas, buried with the strong Brazilian refusal to integrate such a body), and the advance of military American bases in the region.

\footnotetext{
${ }^{146}$ Stella Calloni, "Los Archivos del Horror del Operativo Cóndor," Equipo Nizkor, Derechos.org, Web. 1998.

147 Alejandro Méndez, "UNASUL terá doutrina de defesa independente dos Estados Unidos," Folha de São Paulo, May 27, 2011, p. 15.

148 The U.S. Southern Command is responsible for providing contingency planning, operations, and security cooperation for the Caribbean, Central America and South America. In September 1997, it was reactivated in Miami with priorities and objectives revised, also encompassing anti-drug operations.

${ }^{149}$ Responsible for patrolling the seas in Latin America, it has been disabled at the end of the Second World War and reactivated on July 1st, 2008.
} 
In every respect, the magnitude and the significance of the U.S. military presence in Colombia is the most important political and strategic factor for the South American regional security ${ }^{150}$. Plan Colombia, in which the United States support local government in the fight against drug trafficking and terrorism (mainly the guerrilla FARC), was originally conceived between 1998 and 1999. The American support was earmarked for training and equipping new Colombian army counternarcotics battalions, providing them with helicopters, transport and intelligence assistance, and supplies for coca eradication. ${ }^{151}$

Currently, although in incomparably lower scale than those of the new "strategic regions" of the world, American military presence still provokes mixed reactions from governments of the region. The United States Department of Defense accounts 269 military personnel in all South America countries ${ }^{152}$. These numbers really pale when compared with the 56,051 military troops present in Germany, for instance, which is a country that has the "protection" of the United States since the end of World War II.

However, those movements will gain a character of threat when confronted with the history of American interventions and with the fear of foreign ambitions over South American resources. In the case of Brazil, the intrinsic relevance - or the strategic value - of the national territories distributed in the Amazon (55\% of Brazil), where abundant water resources are concentrated, almost all the remaining hydroelectric potential of the country, some of the largest mineral provinces in the world (including "strategic minerals") and the most formidable biological diversity of the planet.

A central element of military doctrine in Brazil holds the defense of the Amazon as a top priority. During an exercise in the region, military officials stated "the operation will provide ways for optimizing a strategy of resistance in the region". Fifty percent of

\footnotetext{
150 Costa, "O Brasil e a América do Sul".

151 "Empresas Transnacionales de Seguridad Privada en Colombia. Caso Estudio: Plan Colombia," Corporación Colectivo de Abogados José Alvear Restrepo. Web. Feb. 04, 2008.

152 The Department of Defense Base Structure Report 2014 lists: Argentina 16, Bolivia 12, Brazil 50, Chile 33, Colombia 57, Ecuador 24, Paraguay 10, Peru 42, Uruguay 14, Venezuela 9 and Suriname 2. However, the United States involved DynCorp, and other private security companies in their assistance.
} 
Brazilians believe that their country will be assaulted in an effort to grab the Amazon's resources, according to 2011 opinion survey by a government statistics agency ${ }^{153}$.

To highlight the source of conflicts in South America and, consequently, identify perceived security threats to Brazil, we exploited a database of historic events.

Philip Schrodt remembers that the basis of many studies of foreign policy is the fundamental question of "who did what to whom?" During the Nixon administration (1968-1974), he cites, the United States and the Soviet Union had a relaxation of diplomatic tensions known as the détente period. This was reflected in a variety of foreign policy actions, including arms control agreements, a decrease in hostile rhetoric, increased trade, and increased cooperation in resolving disputes. A decision maker living during this period would have a general perception that the hostility between the two superpowers had decreased. However, this perception would be based on a general pattern of cooperative interaction, rather than on a single incident $^{154}$.

To capture this "general pattern" of interaction within South America, we employed GDELT - Global Data on Events, Location and Tone, a database that presents many advantages to our study ${ }^{155}$ :

a) Coverage of all countries of the world.

b) Records based on the cross section of the main sources of international news, national and local, both printed and internet based, both in English and in local language.

c) Fifty-eight fields for each record in order to capture all the details available for the events and actors.

d) All records are georeferenced.

e) The accuracy of the system allows the capture of ambiguous events, and the performance of filtering and linguistic reissue, increasing its reliability.

f) Open System, unreserved and available for unrestricted use.

\footnotetext{
153 Simon Romero, "Brazil Military Drills to Defend Amazon," The New York Times, Nov. 8, 2014.

154 Schrodt, "Event Data in Foreign Policy Analysis", p. 2.

155 James E. Yonamine, "Predicting Future Levels of Violence in Afghanistan Districts Using GDELT", Jay Yonamine, Web. Apr. 12, 2013.
} 
We analyzed a number of 139,857 events ${ }^{156}$, calculating, for each country in South America, the event indices of conflict in some chosen years. We also included three great powers that could also affect the security environment of the system: the United States - as we had seen, a major actor for South American continent - Russia and China ${ }^{157}$. The filtering was performed by a set of scripts elaborated to R platform, a software for statistical and graphics computation of free distribution ${ }^{158}$. The score of each country represents its measure of conflict. The higher the index in the table, the greater that state "contributed" to conflict in the system.

Figure 8: Goldstein Index within South America

\begin{tabular}{|l|r|r|r|r|r|r|r|r|r|r|r|r|r|}
\hline & $\mathbf{1 9 8 0}$ & & $\mathbf{1 9 8 5}$ & & $\mathbf{1 9 9 0}$ & & $\mathbf{1 9 9 5}$ & & $\mathbf{2 0 0 0}$ & & $\mathbf{2 0 0 5}$ & & $\mathbf{2 0 0 8}$ \\
\hline US & -709.1 & US & -1353.7 & US & -2409.2 & PE & -4526.2 & CO & -5864.8 & US & -4505.3 & CO & -29426.9 \\
\hline AR & -316.1 & CO & -615.8 & CO & -2139.6 & EC & -4216.1 & US & -5537 & CO & -4120.4 & US & -21507.7 \\
\hline BL & -282 & PE & -366 & PE & -579 & US & -2888.5 & BR & -2058.7 & VE & -3918.4 & VE & -18585.2 \\
\hline CO & -243.5 & AR & -327.2 & BL & -499 & CO & -2405.6 & VE & -1743.3 & BR & -2158.4 & EC & -13637.7 \\
\hline CI & -175.7 & BR & -267.1 & AR & -322.6 & Cl & -1104 & PE & -1694.9 & PE & -1131.4 & BR & -5787.8 \\
\hline BR & -154.3 & Cl & -246.3 & Cl & -236.3 & AR & -1077.1 & AR & -1619.3 & AR & -1130.9 & BL & -4470 \\
\hline PA & -140.1 & EC & -163.8 & VE & -219.4 & VE & -1042.2 & PA & -987.7 & Cl & -1121.5 & PE & -3334.7 \\
\hline GY & -85.5 & VE & -123.7 & BR & -216.5 & BR & -989.7 & EC & -959.3 & EC & -835.6 & AR & -2887.7 \\
\hline UY & -70.4 & UY & -108.5 & EC & -196 & BL & -269.1 & Cl & -893.5 & BL & -462.2 & RS & -2039.2 \\
\hline VE & -69.6 & PA & -105.4 & UY & -78.5 & PA & -151 & BL & -725.6 & PA & -464.5 & CI & -1885 \\
\hline PE & -71.9 & RS & -84.7 & NS & -66 & UY & -138.1 & RS & -369.9 & RS & -362.4 & PA & -907.4 \\
\hline EC & -67.6 & GY & -63 & RS & -39 & GY & -102 & GY & -225.4 & GY & -152.6 & CH & -626.2 \\
\hline RS & -56.8 & CH & -33 & PA & -36.2 & RS & -45.5 & UY & -148.1 & UY & -132.3 & UY & -518.2 \\
\hline CH & -26.5 & BL & -27 & GY & -10 & CH & -37 & CH & -117.9 & CH & -70.9 & GY & -367.9 \\
\hline NS & 0 & NS & -5 & CH & -5 & NS & -7.4 & NS & -62.6 & NS & -49.4 & NS & -143.6 \\
\hline
\end{tabular}

$\mathrm{Cl}=$ Chile, $\mathrm{CH}=$ China, $\mathrm{RS}=$ Russia, $\mathrm{NS}=$ Suriname

Source: Elaborated by the author.

We notice that Russia and China never had an effective conflictive weight in South America (although we see an increasing trend in the case of Russia), but the

\footnotetext{
156 This is the total sum of 2,562 events for $1980,4,550$ for $1985,5,508$ for $1990,13,310$ for 1995 , 21,228 for $2000,15,531$ for 2005 , and 77,168 events for 2008 .

157 The interactions between these three countries were not computed. Only their conflictive interactions with each South American country is represented in the table.

158 R Development Core Team, "R: A Language and Environment for Statistical Computing," $R$ Foundation for Statistical Computing. Vienna, Austria (2011).
} 
United States are the main source of conflict in the region in almost all observations. In 1995, when that country scored the third index, Peru and Ecuador fought over control of a disputed area on the border between the two countries, and then got the top. In the following graph, we maintained only the countries with the main scores, for clarity purposes.

Figure 9: Intensity of Conflictive Interactions within South America - 1980-2008

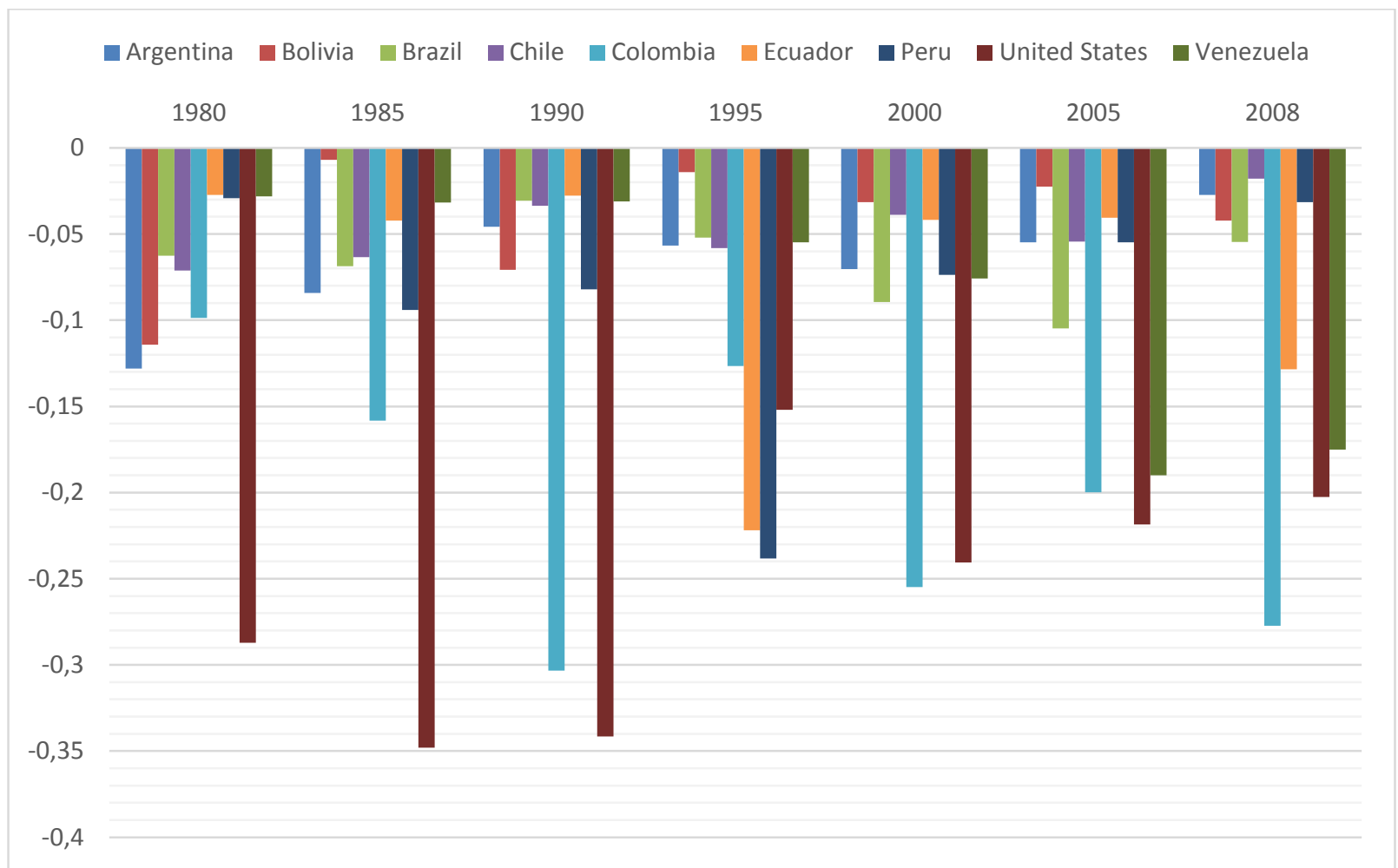

Source: Elaborated by the author.

With a "panoramic view", we can identify the most conflictive state in the system, the most "quarrelsome" country. According to realist theory, we should expect the "biggest ball in the pool" to be a source of problems. If we keep our analysis within South American countries, the big ball should be Brazil, but the country never scored too high in conflictive relations index. Joining the United States (surely "the" big ball) to the framework, allow us to develop a comprehensive analysis and attest that the super-power maintains a high degree of conflict in the region. This could be attributed to American security concerns (its interaction with Colombia and the drugs problem), for economic or political reasons. The fact is: the United States keeps its prominence (not perceived in a good way) for a long period, although we may recognize a reduction 
in this trend from the 2000s.

As we saw, geography is not a main concern to Brazil, since its boundaries disputes were settled more than a hundred years ago and South America enjoys relatively peaceful relations among its countries. Nevertheless, Brazil perceives a threat to its status and to its security from the biggest power in the system, acting freely (but not as assertive as in other regions of the world) in its hegemonic region. The threat that the United States represent is maximized by the perception, solidified in the minds of Brazilian leaders, that the superpower utilize any means to accomplish its objectives of global leadership.

The next chapter will show why currently Brazilian (and South American) leaders and many intellectuals perceive the United States in such manner and why this could be a factor catalyzing a revision of the system and a balancing behavior. 


\section{INTERVENING VARIABLE: DOMESTIC FACTORS}

Fareed Zakaria's study of US expansion in the period of 1865-1908, From Wealth to Power - The Unusual Origins of America's World Role, seeks to answer a puzzling question: the U.S. had economic strength and awe-inspiring relative power for much of its history, but why did it not expand more and sooner? Zakaria found the explanation at the unit level. In the American case, the state ultimately had to wrestle resources from society and gain a free hand to allocate them to foreign policy. ${ }^{159}$

Domestic factors also explains much of Brazilian behavior in the international system. The country's rise in relative power coincides, in temporality, with a Brazilian - and South American - political phenomenon: the rise of leftist governments.

On December 22nd, 1992, the Paraguayan lawyer and former political prisoner Martín Almada, and the judge José Agustín Fernández were looking for Almada's criminal records in a police station in Asunción when they found, instead, archives describing the fates of thousands of Latin Americans who had been secretly kidnapped, tortured, and killed by the security services of Argentina, Bolivia, Brazil, Chile, Paraguay, and Uruguay.

The "Archives of Terror" confirms suspicions that South American countries such as Argentina, Chile, Brazil, Uruguay, and Paraguay engaged in the clandestine exchange of intelligence and prisoners from the mid-1970s through the early 1980s, and responded to the perceived communist menace by detaining, torturing, and "disappearing" political opponents. The files shows evidence that approximately 50,000 people were murdered, 30,000 people disappeared and circa 400,000 were imprisoned as a direct result of this cooperation of states.

The documents attested that the intelligence services of the countries had hold formal meetings to plan what they named "Operation Condor". The operation was established to find suspected of having affiliations with radical leftist movements and put them into concentration camps and secret detention centers. Many "disappeared" - they were tortured, interrogated, executed and secretly buried ${ }^{160}$.

159 Fareed Zakaria, From Wealth to Power. The Unusual Origins of America's World Role (Princeton: Princeton University Press, 1998), p. 35.

160 Remi Brulin, "Operation Condor: Setting precedent from one 'war on terrorism' to the next," $A l$ Jazeera, Sep. 29, 2013. 
Some researches posit that the United States not only knew what was happening in the country, but also provided financial and technical assistance and facilitated greater coordination among intelligence services in the region ${ }^{161}$. This support was grounded on the containment policy of the Cold War.

Many leaders that are currently part of South American elites - intellectuals, politicians, and unionists among them - were persecuted, imprisoned and tortured during these regimes. They are now exerting influence within South American countries. Brazilian President Dilma Rousseff was imprisoned and tortured during Brazilian military dictatorship, and Chilean President Michelle Bachelet was also imprisoned and tortured with her mother. Her father was murdered by Pinochet's regime. The perceptions that these leaderships possess of American influence (political or economic) has, mandatorily, a debased and damnable bias.

The leftist doctrine started to have a prominent role in South American politics by 1998 , when Hugo Chávez won Venezuela's presidential election handily ${ }^{162}$. In Argentina, Néstor Kirchner came to power in 2003, structuring a government that comprised a number of former followers of the Montonero guerrillas ${ }^{163}$.

Another popular leader was Luiz Inácio "Lula" da Silva, of the Brazilian Workers' Party, elected in 2002. Like Chávez, Lula was born into poverty and as a boy sold peanuts and shined shoes. Lula's political trial by fire, however, came through labor union organizing. During the 1980s, he organized key strikes against foreign businesses in the industrial ABC region of São Paulo, Brazil's largest city. ${ }^{164}$

By the year of 2014, South America is led, in many cases, by the oppositionists of the 70 s and 80 s regimes. While the movements differ in many respects from country to country, they all share antipathy towards U.S. political, economic, and military

\footnotetext{
161 See Calloni, 1998. See also the secret memorandum sent by American Assistant Secretary for Latin America Harry Shlaudeman to Secretary of State Henry Kissinger on August 3, 1976.

162 Charlie Devereux and Raymond Colitt, "Venezuelans' Quality of Life Improved in UN Index under Chavez," Bloomberg L.P, March 7, 2013.

${ }^{163}$ An Argentine leftist urban guerrilla and subversive group, active during the 1960s and 1970s.

164 Nikolas Kozloff, Revolution! South America and the Rise of the New Left (New York: Palgrave Macmillan, 2008), p. 27.
} 
control. The growth in power and influence of these movements undoubtedly represents an enormous ideological setback for the United States. ${ }^{165}$

"Pink tide" or Turn to the Left are phrases used in contemporary 21st century political analysis, in the media and elsewhere, to describe the perception that leftist ideology in general, and left-wing politics in particular, are increasingly influential in Latin America. In geopolitical ways, the region has undergone a massive realignment.

One common element of the pink tide is a clean break with what was known at the outset of the 1990s as the "Washington consensus", the mixture of open markets and privatization pushed by the United States. Conservative governments have virtually disappeared from the region.

Figure 10: Left-right political spectrum in Latin America - 2014

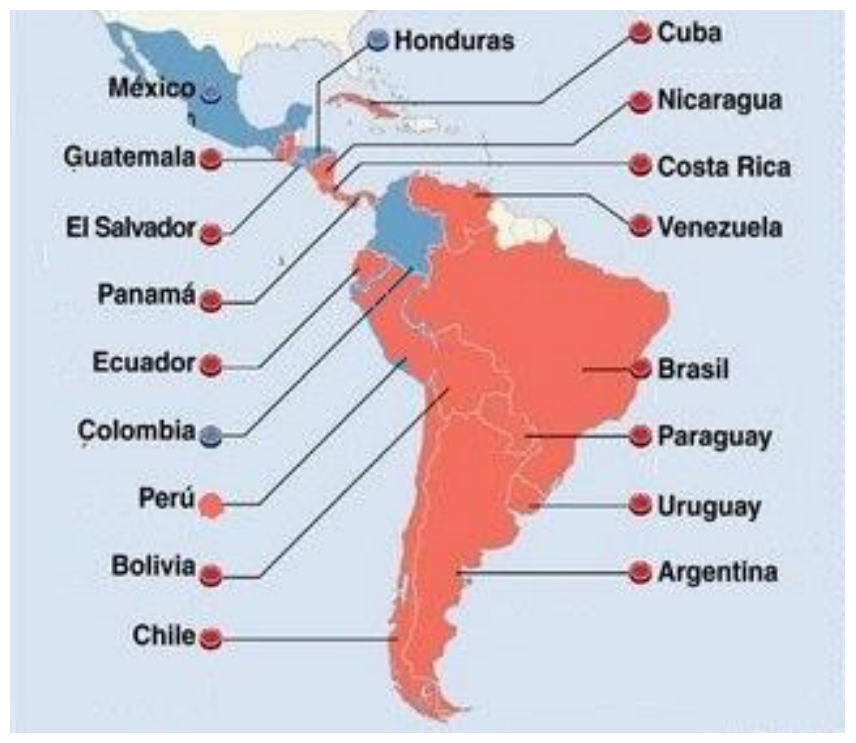

Source: Adapted from "Latin America's Year of Elections", BBC News, Nov. 24, 2005. http://news.bbc.co.uk/2/shared/spl/hi/americas/06/year_of_elections/html/nn1page1.stm (accessed Jan 21, 2014).

When the former Brazilian Chief of Foreign Affairs and current Ministry of Defense, Celso Amorim, was argued whether there was a "leftist movement" in Latin America, he posited:

165 Kozloff, Revolution!, p. 22. 
"There is, no doubt, a trend of more governments committed to social reform, with greater autonomy from the major powers of the world and the desire to regional integration. If you identify with the left vision of progress, social reform, democracy and strong defense of national interests, the answer to your question is yes."166

Octavio Amorim Neto corroborates this analysis in a study where he assess the driving and the determinants of Brazilian foreign policy ${ }^{167}$. Since President Fernando Henrique Cardoso (1995-2002), Brazilian diplomacy has been increasingly presidential. Even though, Amorim Neto statistically verified that main domestic factor to repel Brazil from the United States is the ministerial strength of the left. This reflects the degree of participation of political organizations with intense preferences regarding foreign policy in the decisive arena for this, the Executive. Furthermore, in Brazil, where the President mounts his cabinet, the ministerial force of the left is highly correlated to the President's ideology.

A domestic context of a leftist government is certainly a powerful engine shaping Brazilian expectations and motivations in the international system. Triggering and intervening factors analyzed, we will now explore Brazilian revisionist posture, an ambition that is long embedded in Brazil's politics. The increase in relative power has made the posture conceivable.

166 Eliana Cantanhêde, "Amorim diz que EUA 'pisaram no nosso calo'," Folha de São Paulo, Jan. 23, 2006.

167 Octavio Amorim Neto, De Dutra a Lula (São Paulo: Elsevier, 2011). 


\section{DEPENDENT VARIABLE: REVISIONISM}

This section analyzes the dependent variable of our causal chain. Growths in a state's relative power will impulse that state to revise its role in the international system. This is not a direct relation, though. Some factors located in the state level may influence a country's pursue of change, and will dictate the intensity of this revision.

After examining Brazil's raise in the international domain, mainly result of economic factors, we assessed the subjects that intervened in Brazilian perception of constraints. The national engraved urge for autonomy, a perception of threat instigated by American movements - "the big ball" - and a domestic context of leftist governments should drive Brazil to revise the system. Following our work, we are going to understand how these factors are being translated into reaction.

In 1969, Robert Keohane developed a categorization for world powers that comprehended a psychological as well as a material dimension ${ }^{168}$. He asserted that Great Powers and small powers "develop behavioral patterns which decisively separate them from non-group members" ${ }^{169}$. Keohane suggests an approach that instead of focusing on perceptions of whether security can be maintained primarily with one's own resources, should focus on the systemic role that states' leaders see their countries playing.

Keohane classifies states in four groups. The "system-determining" state plays a critical role in shaping the system: it is the "imperial power" in a unipolar system, or the two Superpowers in a bipolar system. In a second category are "system-influencing" states, which cannot expect individually to dominate a system but may be able to significantly influence through unilateral as well as multilateral actions. Thirdly, some states that cannot hope to affect the system acting alone, although they can exert significant impact on the system by working through small groups or alliances or through universal or regional international organizations: these may be labeled "system-affecting". Finally, most international systems contain some states that can do little to influence the system-wide forces that affect them, except in groups which are so large that each state has minimal influence and which may themselves be dominated by larger powers. For these small, "system-ineffectual" states, foreign policy

168 Robert O. Keohane, "Lilliputians' Dilemmas: Small States in International Politics," International Organization 23, № 2 (1969): p. 293.

169 lbid., p. 292. 
is adjustment to reality, not rearrangement of it. ${ }^{170}$

Keohane broadly classified some countries, considering the United States and the Soviet Union as "system-determining"; the United Kingdom, France, West Germany, Japan, Communist China, and India as "system-influencing"; Canada, Sweden, Pakistan, Brazil, Argentina and comparable states "system-affecting". An array of other states, he calls "system-ineffectual".

Currently, Brazil's attributes of power place the country in the systeminfluencing group. The state cannot individually dominate the international system; however, it is determined to influence its nature through unilateral, and, more assertively, through multilateral actions.

A founding member of the League of the Nations and the United Nations, Brazil sent troops to fight with the Allies in World War II, but it never aspired to lead Latin America. During the period of military rule in the 1960s, 1970s, and 1980s, Brazil successfully projected itself as a leading nonaligned country ${ }^{171}$.

In the 2000s, Brazil started to evolve from its traditional reclusiveness. The country's success on the home front, together with radical shifts in global politics and economics, has generated a new story line - one that was crystallized under Lula administration - that explains the increase in the country's ambition towards the international system. Julia Sweig see, in this new narrative, recalls of the manifest destiny of nineteenth-century America, with a Brazilian twist ${ }^{172}$.

With neither blood spilled nor territory annexed, Brazil consolidated a multiethnic and multiracial democracy, stabilized a strong market economy, and lifted millions into a growing middle class. Considered a gigantic nation, be it in territorial or population terms, Brazilians argue that by virtue of these accomplishments, the country is entitled to be seen as a global power and to act as one ${ }^{173}$.

Brazil's major foreign policy conjoins autonomy with an aspiration to achieve international recognition in accordance with its self-perception of a "big country"174. Brazil has demonstrated a clear intention of expanding the roles that it plays and the

\footnotetext{
170 Keohane, Lilliputians' Dilemmas.

171 Julia E. Sweig, "A New Global Player: Brazil's Far-Flung Agenda," Foreign Affairs 89, no. 6 (2010): p. 175.

172 lbid., p. 175.

173 Andrés Malamud, "A Leader Without Followers? The Growing Divergence Between the Regional and Global Performance of Brazilian Foreign Policy," Latin American Politics and Society 53, no. 3 (2011).

174 Lima and Hirst, "Brazil as an Intermediate State", p. 21.
} 
responsibilities that it assumes in regional politics, in Third World agendas and in multilateral institutions.

Positioned as the sixth biggest world economy in $2011^{175}$, an increasingly confident Brazil has undertaken an ambitious and extended foreign policy agenda. This quest has included efforts to secure a seat on an expanded UN Security Council, to organize major and minor developing countries into a stronger coalition within the Doha trade talks, and to expand voting rights for itself and others at the World Bank and the International Monetary Fund. ${ }^{176}$

The aspiration to revise the world order is illustrated by the statement presented by Brazilian President Dilma Rousseff in the $66^{\text {th }}$ session of the United Nations General Assembly:

"The role of the Security Council is vital - and the more legitimate its decisions are, the better it will be able to play its role. And the Council's legitimacy increasingly hangs on its reform. With each passing year, it becomes more urgent to solve the Council's lack of representativeness, which undermines its credibility and effectiveness ${ }^{177 . "}$

Rousseff's discourse is simply sustaining a longstanding Brazilian revisionist policy. Former President Luís Inácio Lula da Silva, who maximized the "Brazilian Manifest Destiny", posits that before he was elected the country

"already had a vocation to do what we did, from the point of view of integrating Latin America, of the relationship with African states, of creating a great diversity on international relations. One of the things we literally recorded is that we would not allow the Free Trade Area of the Americas (FTAA) to happen on this continent ${ }^{178}$."

The aspiration to revise the system and become a "big ball" with more freedom of movement is long present in Brazil's intentions. The increase in power made it more conceivable. The revisionist character of the Brazilian state was long established, although the country had no power to act consistently.

Nevertheless, Brazil's growing power over the course of the past decade simply did "not allow us to stay indifferent to these questions," said Former Foreign Affairs Minister, Celso Amorim, in a speech to the Brazilian diplomatic corps two days

\footnotetext{
175 In 2013, Brazil had the seventh biggest world economy.

176 Sweig, "A New Global Player," p. 175.

177 Dilma Rousseff, (Statement at the Opening of the General Debate of the 66th Session of the United Nations General Assembly, New York, NY, Sep. 21, 2011).

178 Luís Inácio Lula da Silva, "O Brasil no mundo: mudanças e transformações," (Statement at Conferência Nacional 2003-2013: Uma Nova Política Externa, São Bernardo do Campo, SP, Jul. 15$18,2013)$.
} 
after signing the nuclear agreement between Brazil, Turkey and Iran known as the Tehran Declaration ${ }^{179}$.

Until this section, our study followed a realist causal chain to verify the consequences of Brazil's raise in relative power. The end of this chain shows a clear intention of the state to revise the system, or, at least, to have a greater role in international politics.

Our model entails another deployment, though. Waltz understands that a state's security imperatives induces a balancing behavior. Our proposed chain gives other motivations to balancing, such as perceived threats, domestic factors, pursue of glory, power, vital space, and, in Brazilian case, autonomy and a bigger role in world's politics.

The next section of our work will verify if Brazil is in fact adopting a balancing posture in consequence of these factors.

179 Cited in Parsi, A Single Roll of the Dice, p. 176. 


\section{BALANCING}

States try in more or less sensible ways to use the means available in order to achieve the ends in view. Those means fall into two categories: internal efforts, that constitutes moves to increase economic capability, to grow military strength and to develop clever strategies; and external efforts, that rely on moves to strengthen and enlarge one's own alliance or to weaken and shrink an opposing one ${ }^{180}$.

Waltz describes external balancing primarily as a function of security concerns. In an anarchy system, security is the highest end. Because power is a means and not an end, states cannot let power, a possibly useful means, become the end they pursue. ${ }^{181}$ Waltz suggests the superiority of internal balancing considering it is "more reliable and precise than external balancing"182. Nevertheless, Professor Barry Posen explains that, "in a true multipolar system, one simply cannot afford not to engage in external balancing. Arithmetically, internal balancing can never be enough" ${ }^{183}$ to compete against all other powers.

Military force remains a vital source of power in this century because its presence structures expectations and shapes the political calculations of actors. A capacity to fight and coerce, protect and assist will remain important even if interstate war lose space to conflicts among nonstate transnational and insurgent groups or between states and such groups ${ }^{184}$.

Thomas Bendel advances the discussion on balancing options and analyze whether states are likely to pursue one method or the other. The conclusion of his studies asserts that, if internal balancing is more certain than external balancing, those states which can successfully balance internally, should. However, in order for a state to balance successfully, it must be able to develop an amount of power which, compared to that of the state which it is balancing against, is significant. The greater the potential threat, or the greater the capability of the hegemon, the less the relative power of the other actors. Small powers may have little choice but to

\footnotetext{
180 Waltz, Theory of International, p. 118.

181 lbid., p. 126.

182 Ibid., p. 168.

183 Barry Posen, Lecture, Nov. 2014

184 Nye, The Future of Power, pp. 48-49.
} 
enter into alignments as a means for ensuring their goals, even if internal balancing is a superior method ${ }^{185}$.

At the height of the Second World War, the United States spent nearly fortytwo percent of its GNP on defense ${ }^{186}$. Using the United States as a target is, of course, absurd, but even if the target country was a medium power such as Canada, only fiftyfive countries could hope to match its expenditure. Such costs could make even those states which could afford such an expenditure balk. Alliance provides a means to achieve greater defense at lower cost ${ }^{187}$.

\subsection{Brazilian Internal Balancing}

The stable regional environment in which Brazil is inserted explains many of the perceptions shared by the Brazilian elites who constitute the foreign policy community. Foreign threats and risks are perceived to be driven basically by economic and not military/security motivations. The American omnipresence brings some unrest to these elites, but not enough to perceive a territorial threat. The main external vulnerabilities are perceived as being economic, and foreign policy has always had a strongly development component. As a result, prevailing economic model, not military, has very heavily shaped the core of the Brazilian foreign policy agenda ${ }^{188}$.

In História da Política Exterior do Brasil, a fundamental work on Brazilian foreign politics history, Professors Amado Luiz Cervo and Clodoaldo Bueno criticize Brazilian Ministry of Foreign Affairs because of the idealist inspiration of its initiatives that depressed the role of the armed forces. ${ }^{189}$ They understand that Brazilian foreign politics disqualified force as a means of action in favor of persuasion. The pacifist initiatives, they argue, were effective to influence disarmament in Southern Cone, but distanced the country from great powers political realism and embarked on utopia ${ }^{190}$.

\footnotetext{
185 Thomas Richard Bendel, "On the Types of Balancing Behavior" (PhD diss., Naval Postgraduate School, Dec. 1994), p. 58.

186 U. S. Department of Commerce, U. S. Census Bureau, Historical Statistics of the United States, Colonial Times to 1970, 1975, Washington, DC.

187 Bendel, "On the Types of Balancing Behavior", pp. 51-52.

188 Lima and Hirst, "Brazil as an Intermediate State", p. 22.

189 Amado Luiz Cervo and Clodoaldo Bueno, História da Política Exterior do Brasil (Brasília: Editora Universidade de Brasília, 1992), pp. 468-471.

190 Ibid., 469.
} 
A rapid look on the distribution of Brazilian military expenditures will support this idea.

Figure 11: Distribution of Brazilian Military Expenses

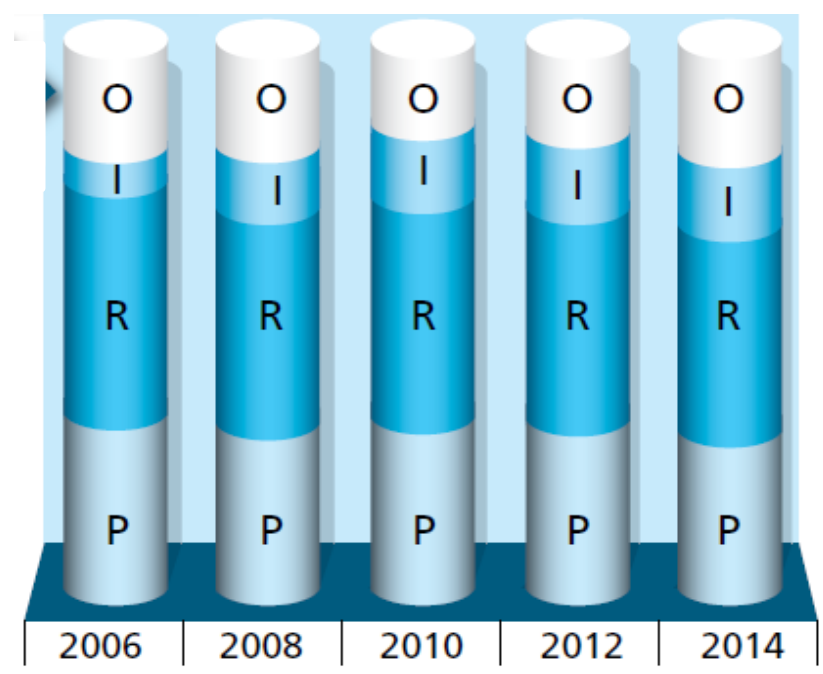

$\mathbf{R}=$ Retirement and pensions $\mathbf{P}=$ Salaries and other allowances $\mathbf{I}=$ Investments $\mathbf{O}=$ Other expenses Source: Red de Seguridad y Defensa de América Latina, Atlas Comparativo de la Defensa en América Latina y Caribe (Buenos Aires: RESDAL, 2014).

In 2013, despite the Ministry of Defense had received the fourth-largest budget in the government (after social security, health and education), only $14 \%$ was allocated on material investment and acquisitions, with a majority of its spending being dragged by pensions, as we see in the figure above. ${ }^{191}$

The size of Brazilian armed forces $\left(333,973\right.$ men $\left.^{192}\right)$ is $16 \%$ of that of the United States $\left(2,115,045\right.$ military and civilians $\left.{ }^{193}\right)$. Brazil has a low military spending compared to U.S. or even if paralleled with other BRIC country. It represented approximately $20 \%$ of China military expenditures and less than $5 \%$ of U.S. spending. ${ }^{194}$

\footnotetext{
191 Mathilde Chatin, "Brazil: a new powerhouse without military strength?" BRICS Policy Center (2013), pp. 2-3.

192 Red de Seguridad y Defensa de América Latina, Atlas Comparativo.

193 U.S. Department of Defense, Base Structure Report, Washington, DC, 2014.

${ }^{194}$ Stockholm International Peace Research Institute (SIPRI), "Military Expenditure Database," Web. 2014.
} 
Figure 12: Comparative Brazilian-Chinese Military Expenditures ${ }^{195}$

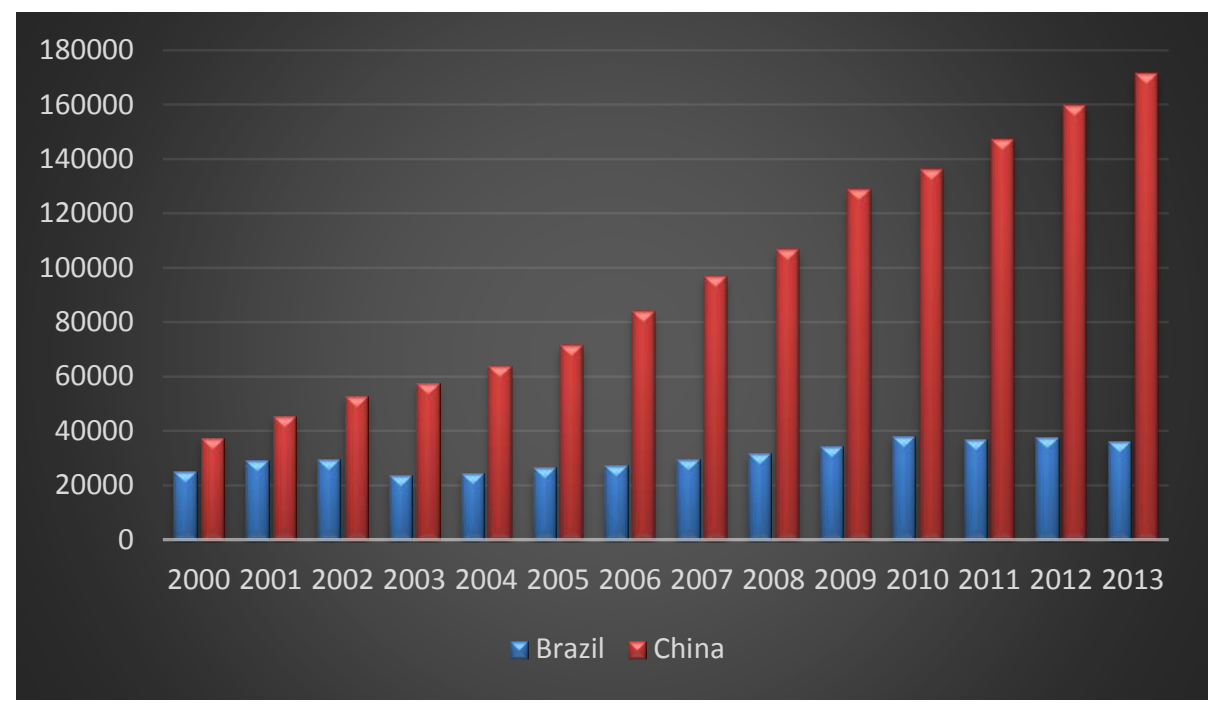

Source: Elaborated by the author.

Figure 13: Comparative Brazilian-Chinese-American Military Expenditure ${ }^{196}$

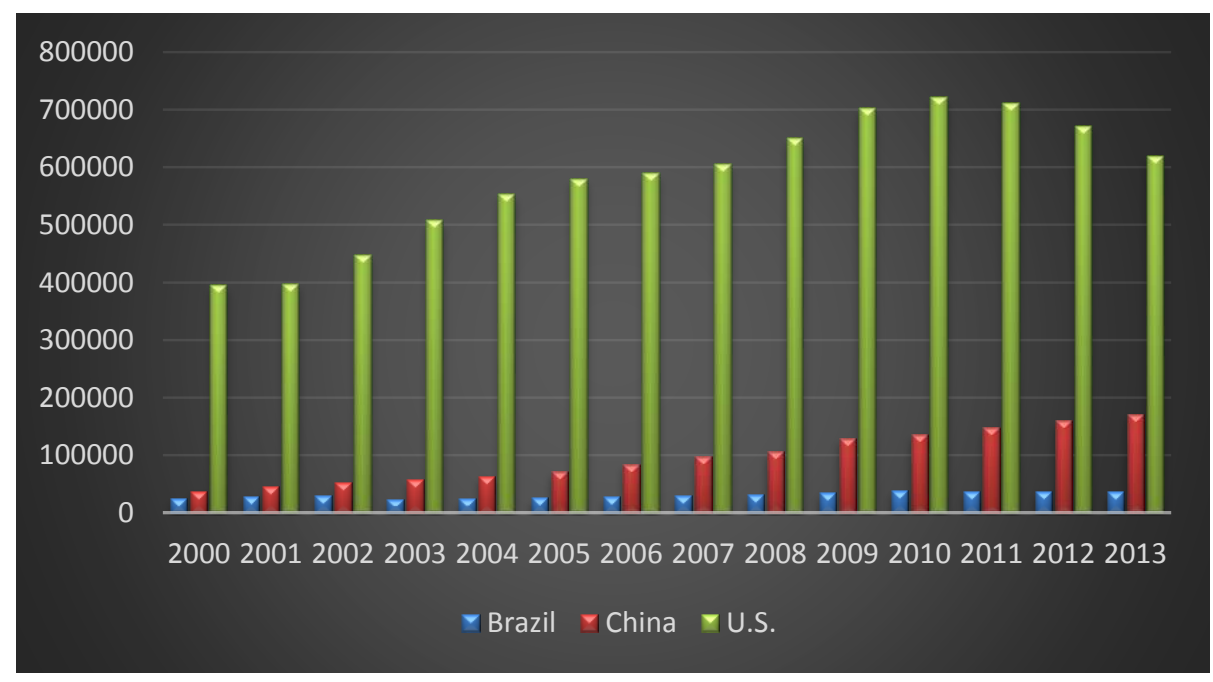

Source: Elaborated by the author.

For a simpler evaluation of military power, we turned to the Global Firepower Index (GFI), a ranking of 106 nations based on more than 50 factors including manpower (i.e., total population, fit for service), land systems (i.e., tanks, artillery pieces, vehicles), air power (i.e., total aircraft, serviceable airports), naval power (i.e., total ships, aircraft carriers, destroyers, mine capability), natural resources (oil production and reserves), logistics (i.e., labor force, roadways and railways) and

195 SIPRI, "Military Expenditure Database".

196 Ibid. 
financial (i.e., annual defense budget, debt, reserves in foreign exchange and gold). 197

The index focuses on quantity, ignoring significant qualitative differences North Korea's 78 submarines, for instance, are not exactly state of the art. It also does not factor in nuclear stockpiles, which are still the ultimate trump card in geopolitics. Global Firepower Ranking is not a scientific method to measure military power, and it acknowledges his sources are from public domain, such as CIA.gov, CIA World Factbook, media sources, etc. Nevertheless, we can use it to illustrate Brazil's relative military power.

Figure 14: South American Countries Ranked by Military Power (2014)

\begin{tabular}{c|l|l} 
RANKING & COUNTRY & GFP PWRINDX \\
\hline $\mathbf{1 .}$ & Brazil & 0.6663 \\
$\mathbf{2 .}$ & Colombia & 1.6234 \\
$\mathbf{3 .}$ & Argentina & 1.6242 \\
$\mathbf{4 .}$ & Chile & 1.6523 \\
$\mathbf{5 .}$ & Peru & 1.6926 \\
$\mathbf{6 .}$ & Venezuela & 1.7343 \\
$\mathbf{7 .}$ & Ecuador & 2.3045 \\
$\mathbf{8 .}$ & Paraguay & 2.7651 \\
$\mathbf{9 .}$ & Bolivia & 2.7841 \\
$\mathbf{1 0 .}$ & Uruguay & 3.6352
\end{tabular}

Source: Global Firepower, “World Ranking of Power,” Web. 2014.

Brazil is unequivocally stronger than its South American peers, even if we consider that currently it has a military budget relatively smaller than that of other South American countries like Venezuela, Colombia and Chile. Factors such as natural resources and logistics contribute to increase Brazilian index.

However, when we bring the country to the world arena, Brazil scores a fragile fourteenth position.

197 Global Firepower, "World Ranking of Power," Web. 2014. 
Figure 15: World States Ranked by Military Power (2014)

\begin{tabular}{c|l|l} 
RANKING & COUNTRY & GFP PWRINDX \\
\hline $\mathbf{1 .}$ & UNITED STATES & 0.2208 \\
$\mathbf{2 .}$ & RUSSIA & 0.2355 \\
$\mathbf{3 .}$ & CHINA & 0.2594 \\
$\mathbf{4 .}$ & INDIA & 0.3872 \\
$\mathbf{5 .}$ & UNITED KINGDOM & 0.3923 \\
$\mathbf{6 .}$ & FRANCE & 0.4706 \\
$\mathbf{7 .}$ & GERMANY & 0.4899 \\
$\mathbf{8 .}$ & TURKEY & 0.5171 \\
$\mathbf{9 .}$ & SOUTH KOREA & 0.5536 \\
$\mathbf{1 0 .}$ & JAPAN & 0.5581 \\
$\mathbf{1 1 .}$ & ISRAEL & 0.5887 \\
$\mathbf{1 2 .}$ & ITALY & 0.5991 \\
$\mathbf{1 3 .}$ & EGYPT & 0.6122 \\
$\mathbf{1 4 .}$ & BRAZIL & 0.6663 \\
$\mathbf{1 5 .}$ & PAKISTAN & 0.7369
\end{tabular}

Source: Global Firepower, “World Ranking of Power,” Web. 2014.

Maria Regina Soares de Lima and Mônica Hirst recognize that, since Brazil rests in a zone of relative peace in South America, and has continuously reinforced a sense of territorial satisfaction, Brazilian political and intellectual circles do not value military deterrence as a source of international and/or regional prestige. ${ }^{198}$

Even though, we can verify an increase in the absolute extent of military expenditures due to the growth in Brazilian GDP. In the last ten years, defense budget has growth approximately $56 \%$, although the percentage of GDP addressed to the armed forces remained in circa $1.5 \%$.

198 Lima and Hirst, "Brazil as an Intermediate State", p. 38. 
Figure 16: Brazilian Military Expenditures (US \$m ) ${ }^{199}$

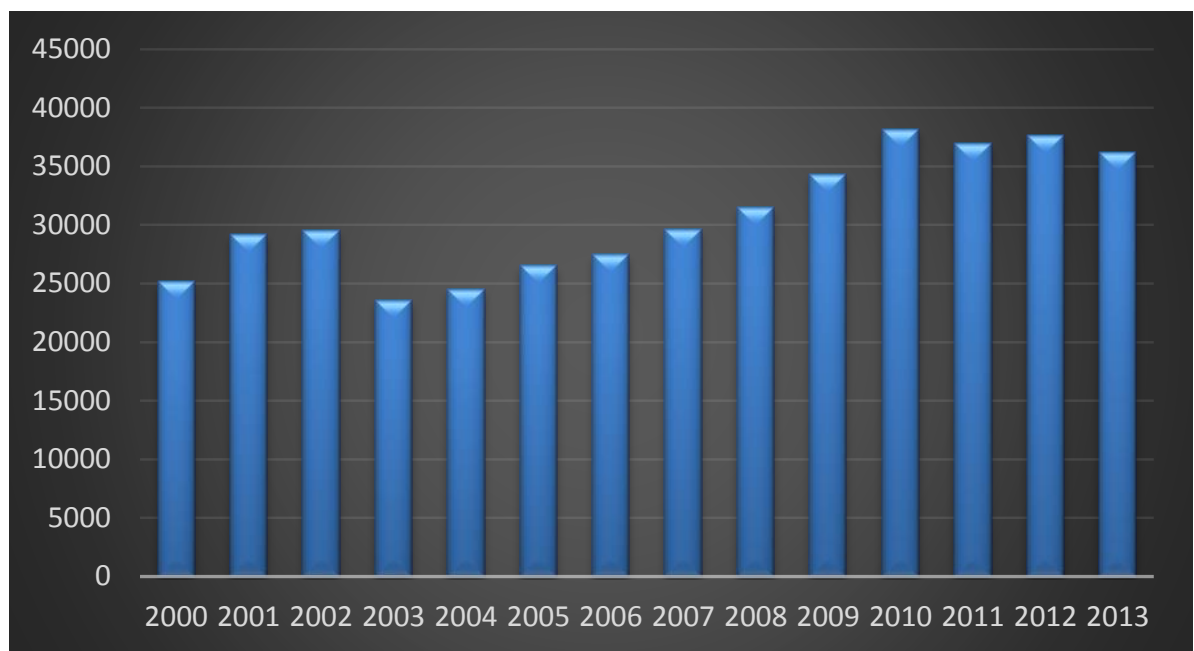

Source: Elaborated by the author.

Figure 17: Brazilian Military Expenditures (Share of GDP)

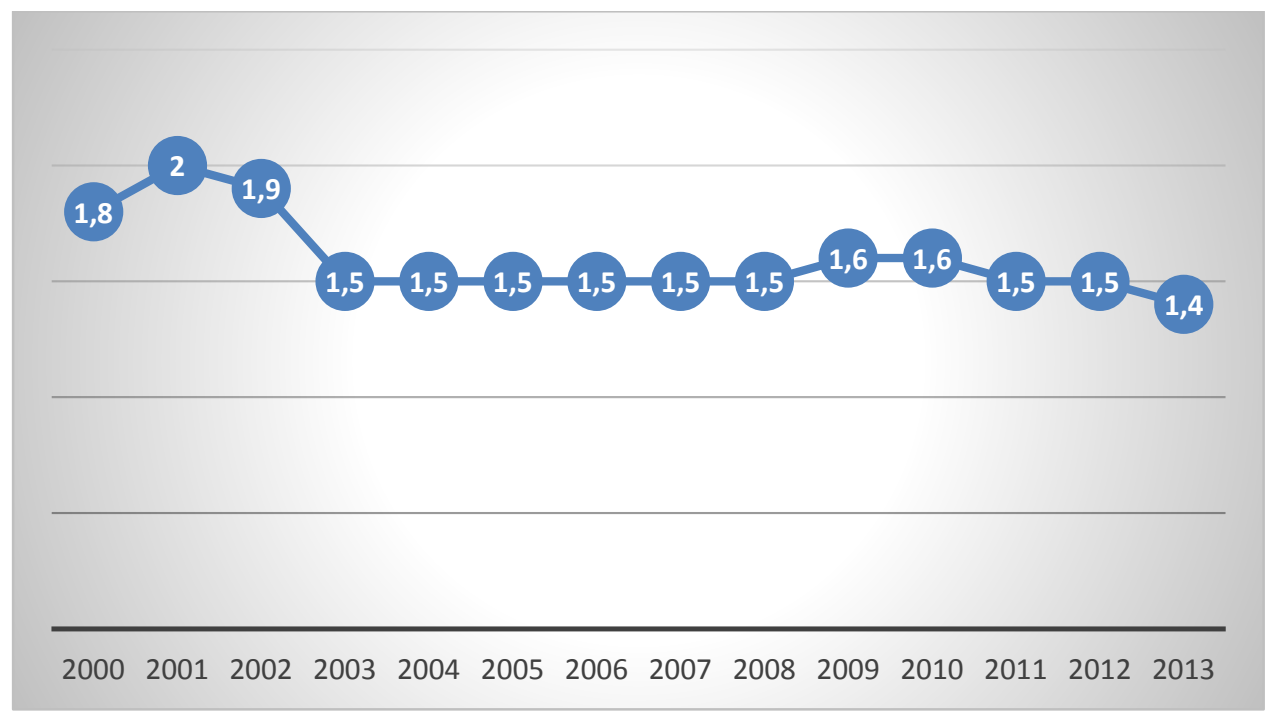

Source: Elaborated by the author.

Nevertheless, there are some indications that Brazilian government is trying to improve its internal capabilities (even if not as strongly as some other raising states). Two defense programs that have been undeveloped for more than a decade had recently advanced in Brazilian agenda: the navy nuclear submarine program and the air force project FX-2.

199 Figures are in US \$m., at constant 2011 prices and exchange rates, except for the last figure, which is in US \$m. at 2013 prices and exchange rates. 
Brazilian first nuclear-powered attack submarine was announced for start of operations by 2021.

Aspirations to develop a nuclear-powered submarine was long established. In 1967, during the National Security Council meeting that discussed the guidelines for the Brazilian nuclear policy in Costa e Silva's government (1967-1969), the Minister of the Navy emphasized the importance of nuclear energy for them since it could be used to propel a nuclear vessel. He stressed, "the navy has been dealing with the question of nuclear energy because it considers that indispensable"200.

Under the protection of the mentioned secret "Autonomous Nuclear Program", the navy developed indigenous capacity to enrich uranium by $1984^{201}$, but the project remained stationary. The program was stimulated by a 2008 nuclear cooperation agreement with France that also includes the joint development of four conventional submarines.

The inauguration of a naval shipyard for the construction of conventional and nuclear submarines in the state of Rio de Janeiro in 2013 was another step towards the autonomy for the processes of building and nuclear-powering the vessel, in the same manner of only four other countries in the world: United States, China, Great Britain and France.

The main advantages of the nuclear submarine are its ability to remain submerged for virtually unlimited periods, its deep-diving capability, the sophisticated long-range sensor systems that it carries, and the high power output of its reactor that can be converted into very high underwater speeds ${ }^{202}$.

In theory, the accretion of this capacity could stimulate a security dilemma within South America countries. Nevertheless, the most prominent demonstrations of disagreement did not came from Argentina, Venezuela, Colombia or other state in the region, supposed to perceive it as a threat to their security. Remarkably, the animosities came from journalists and scholars from other regions of the world 203 .

\footnotetext{
200 Brazil, National Security Council, Minutes of the Fortieth Session of the Brazilian National Security Council, Oct. 04, 1967, Brasilia, DF: Archive of Brazilian Foreign Ministry, History and Public Policy Program Digital Archive.

201 Brazil, Congresso Nacional, Relatório Final da Comissão Parlamentar Mista de Inquérito destinada a apurar o Programa Autônomo de Energia Nuclear, 1990, Brasilia, DF.

${ }_{202}$ Chris Chant, Steve Crawford, Martin J. Dougherty, and lan Hogg, Weapons of War - Submarines: 1940-Present (New York: Chartwell Books, 2013), p. 11.

203 See, for example, Michael Moran, Brazil Goes Nuclear; Stephan Zivec, Brazilian Nuclear Submarine; in the Westphalian Journal, Brazil's Monroe Doctrine; and Paul D. Taylor, Why Does Brazil Need Nuclear Submarines?
} 
The new capabilities that will be aggregated to Brazilian military power increases tremendously its range of military action. Brazilian Navy Commander, Admiral Júlio Soares de Moura Neto, stated that

"Brazil's new position in the international context are factors that reinforce the need for deterrence and the submarine fleet have the ability to perform multiple targets of a potential aggressor that threatens wells located on the continental shelf attacks"204.

Aiming the recently discovered pre salt oil reserves, but with a broader impact in the international system, the nuclear submarine satisfies Brazilian protracted aspiration to display its nuclear autonomy ${ }^{205}$, as president Rousseff's words confirm:

"We can say that, in fact, with it we enter the select group of the members of the United Nations Security Council - the only nations who have access to nuclear submarine: United States, China, France, England and Russia." 206

Another ambitious program was announced on December 2013, when the Swedish attack aircraft Gripen NG was selected to equip Brazilian Air Force fleet in a contract of US\$ 5.4 billion. The offer presented to the Brazilian Government by the Swedish company Saab included sub-systems for the aircraft, an extensive technology transfer package, a financing package as well as long term bi-lateral collaboration between the Brazilian and Swedish Governments.

Brazil pursued a model where he could invest in the capacities that ensure independent production potential of its air defense means, revisiting the autonomy paradigm. The generic principle of the program was to refuse extreme solutions either merely purchasing a "fifth generation" fighter aircraft in the international market or sacrificing the purchase to invest in the joint development of a futurist manned jet fighter prototype along with another country. A hybrid solution seems to be convenient, as it shall provide fighter aircrafts within a relatively short time period, but doing this in a way to create the conditions for the national manufacturing of advanced manned jet fighters.

These projects obviously strength Brazilian internal capabilities, but also serves to another proposal: to emphasize to the world Brazil's self-sufficiency through

\footnotetext{
${ }^{204}$ Agência Estado, "Brasil Planeja Frota com Seis Submarinos Nucleares," O Estado de São Paulo, Nov. 21, 2010.

205 Carlos Patti, "O programa nuclear brasileiro entre passado e futuro," Boletim Meridiano 47, no. 14 (2013).

206 Rousseff, "Discurso na Cerimônia de Inauguração".
} 
technological achievements.

This general picture of Brazilian internal capabilities demonstrates that the country's elites are not prone to balancing internally, basically, because within its region, Brazil is the status quo power. On the other hand, our intervening variables are producing some effects in this scenario, and the perception of the United States as a threat, conjugated with the conviction that its natural resources must be protected from the ambitions of great powers, are pushing the government to invest more firmly in military capacity.

Although the percentage of GDP allocated to the Ministry of Defense remains almost unaltered through more than ten years, the growth in Brazilian economics "automatically" caused an increase in military expenditure. This expenditure, however, must be rethought, since only $14 \%$ of the military budget contemplates acquisitions and investments.

To confirm internal balancing, Waltz indicates searching for instances of states making internal efforts to strengthen themselves, despite distasteful or difficult such efforts might be $\mathrm{e}^{207}$. These difficulties are present in Brazilian ingrained discourse for peaceful resolutions of conflicts, as the elites in the country are resilient to the use of military power. This is reflected in defense capabilities that are inferior to those of other intermediate powers. Nonetheless, this section showed that the country is timidly attempting to raise its internal capacity.

In the next part of our study, we will look for instances of external balancing, in accordance with the expectations which neorealist theory gives rise to.

\subsection{Brazilian External Balancing}

The belief that states form alliances in order to prevent stronger powers from dominating them lies at the heart of traditional balance of power theory ${ }^{208}$. Waltz understands external balancing as "moves to strengthen and enlarge one's own alliance or to weaken and shrink an opposing one."209

Stephen Walt identifies in Waltz's approach an example of a broader tendency to frame balancing behavior solely in terms of capabilities. Balancing is alignment with

\footnotetext{
207 Waltz, Theory of International, p. 125.

208 Walt, The Origins of Alliances, p. 18.

209 Waltz, Theory of International, p. 118.
} 
the weaker side, bandwagoning with the stronger ${ }^{210}$.

In Origins of Alliances, Walt presents a diverging theory where states tend to ally with or against the foreign power that poses the greatest threat. To assert Brazilian external balancing, we will adopt Walt's theory as it presents a richer framework.

Walt lists four main factors that influence the decision of states to pursue external balancing, i.e. causes of alliance formation. The first reason is aggregate power, which constitutes the aggressor's resources and capabilities, such as population, industrial and military capability, and technological prowess. According to Walt, this should be the reason why U.S. grand strategy prevents any single state from controlling more industrial resources than the United States do ${ }^{211}$.

The second factor is geographic proximity, whereby physically close states pose a greater threat than distant ones, since the ability to project power declines with distance $^{212}$. Neighboring states that are perceived as aggressive and increasingly powerful are likely to alarm other states to engage in balancing strategies against it.

Offensive power is the third factor, which conveys that states with large and growing offensive capabilities are likely to provoke others to balance against them ${ }^{213}$. Walt argues that offensive power is closely related, but not identical to aggregate power.

The fourth factor concerns aggressive intentions, where states that are perceived as aggressive or expansionist lead others to balance against it. Walt notices that perceptions of intent are likely to play an especially crucial role in alliance choices.

Walt's causal chain is presented in the following arrow diagram.

Figure 18: Walt's Causal Chain for Formation of Alliance

\begin{tabular}{|c|c|c|}
\hline Independent Variable & Intervening Variables & Dependent Variables \\
\hline & \multirow{3}{*}{$\begin{array}{l}\text { - Aggregate power } \\
\text { - Geographic Proximity } \\
\text { - Offensive Power } \\
\text { - Aggressive Intentions }\end{array}$} & \multirow{3}{*}{\begin{tabular}{|c} 
External \\
Balancing \\
(Formation of \\
Alliance)
\end{tabular}} \\
\hline Threat & & \\
\hline Threat & & \\
\hline
\end{tabular}

Source: Elaborated by the author.

210 Walt, The Origins of Alliances, p. 21.

211 lbid., p. 22.

212 Ibid., p. 23.

213 lbid., p. 24. 
In the fourth chapter of this work, we verified that Brazil perceives a threat to its status and to its security from the biggest power in the system, namely the United States. This threat is maximized by the perception, solidified in the minds of Brazilian leaders, that the superpower utilize any means to accomplish its objectives of global leadership.

The previous observations of our work allow us to oppose Walt's model to our case in order to find out in what extent each intervening variable influences Brazilian external balancing.

In this sense, all four aspects contribute to Brazilian decision to form an alliance. One counterargument could be posited, though. It should be argued that there is no geographic proximity between the United States and Brazil. However, we see no "contiguity" between the two states. The only super power in the international system has unequivocally more power available than it would be necessary to influence South American dynamics. In fact, it does.

One movement Brazil could perform would be to align with the source of its threat, namely the United States. Despite this has already happened in the past ${ }^{214}$, this study had showed that Brazil is a raising power looking for its own space and influence in the international system. As Walt argues, allying with the stronger side gives little influence and leaves the state vulnerable to the impulses of its partner ${ }^{215}$.

We can observe two different maneuvers in Brazilian foreign affairs to balance American power. The first one can be aggregate in a variety of initiatives that are classified by Robert Pape as "soft balancing"216. According to Pape's concept, this mechanism is triggered through diplomacy, diplomatic coalitions, international institutions and agreements, as well as economic initiatives and multilateral and regional economic endeavors that exclude the superpower in the process.

A variety of engagements confirms Brazil's soft balance. Brazil's initiative towards the creation of a South American Community; its activist policies and positions in both hemispheric trade negotiations and global trade fora; its efforts to deepen relations with major world powers such as China and Russia; its desire to build up South-South coalitions, particularly with India and South Africa; the promotion of its

\footnotetext{
214 Brazil was for many decades a strong supporter of pan-Americanism, the doctrine of Western Hemispheric cooperation sponsored by the United States. See Onis, 2008 and Pinheiro, 2000.

215 Walt, The Origins of Alliances, p. 19.

${ }^{216}$ Robert A. Pape, "Soft Balancing against the United States," International Security 30, no. 1 (2005).
} 
own candidates to head both the World Trade Organization (WTO) ${ }^{217}$ and the InterDevelopment Bank; and its campaign to become a permanent member of an expanded UN Security Council.

Along these lines, the country promoted pan-ideological South American integration and began forging a loose coalition and dialogue with India and South Africa. Brazil has made major investments in the African continent, especially in Portuguese-speaking nations and other resource-rich countries. Brasília is the national capital that has more embassies from Africa. ${ }^{218}$

In conjunction with an undoubtedly soft balancing, a somewhat conventional external balancing is perceived in the formation of the South American Security Council, a Brazilian collective security initiative.

In the mid of the decade of 2000, it was growing in Brazil's leadership the perception that regional integration would be fundamental for the country to play the role of global player, dividing influence of geopolitical and economic space with the United States. ${ }^{219}$

During a meeting between Presidents Lula of Brazil, Hugo Chavez of Venezuela, and Néstor Kirchner of Argentina, held in Brasilia in 2006, the creation of a Council of South American Defense was submitted. The theme was taken up in October 2007, when the new Brazilian Defense Minister Nelson Jobim, took over the idea that it was necessary to establish "something that can be discussed as a Latin American defense plan."220

In the first half of 2008, two events gave relevance to the topic: the conflict involving Colombia, Ecuador and Venezuela ${ }^{221}$ and the reactivation of the US Fourth Fleet. Such events have driven the debate and promoted a round of talks between defense authorities of the countries of the region.

Finally, on December 16, 2008, during the Extraordinary Meeting of Heads of State of UNASUR (Union of South American States), held in Brazil, the South

\footnotetext{
217 In fact, a Brazilian diplomat, Roberto Azevedo, has been named head of the WTO in 2013.

218 Marcos Formiga, "Brasília supera Londres no número de embaixadas dos países africanos," Conselho Nacional de Desenvolvimento Científico e Tecnológico, Web. Jun. 11, 2013.

219 Sergio Fausto and Bernardo Sorj, "O papel do Brasil na América do Sul: estratégias e percepções mútuas," Política Externa 20, no. 2 (2011).

220 Carolina Pimentel, "Militares brasileiros visitarão países da América Latina para articular plano de defesa para região," Agência Brasil, Oct. 23, 2007.

${ }^{221}$ On March 2008, Colombian security forces crossed the board with Ecuador to attack an installation of the Fuerzas Armadas Revolucionarias Colombianas (FARC). Venezuela mobilized troops to "defend Ecuador".
} 
American Defense Council (Conselho de Defesa Sul-Americano - CDS) was created, as a body for consultation, cooperation and coordination on defense.

Initially, CDS had raised suspicion in several South American countries that believed it would be a platform to export Brazil's military plans, reflecting a strategy of Brazilian "South Americanization", according to which the country would tend to maximize its earnings expanding its relations with South America. ${ }^{222}$

Despite these hesitations, the strong political assertiveness sponsored by Brazilian government, and concerns about the influence of more powerful states over the region coveting their natural resources spoke up. This perception, especially shared among South American military, was highlighted in the CDS statute, which posits as one of their principal objectives "promoting the sovereign defense of natural resources of our nations". ${ }^{223}$ As Walt posits, the immediate threat that offensive capabilities pose may create a strong incentive for others to balance 224 .

The creation of CDS is more remarkable when we put in perspective that almost all countries within South America are still members of the Inter-American Treaty of Reciprocal Assistance (Tratado Interamericano de Asistencia Recíproca TIAR). The treaty, an US initiative in light of the developing Cold War and following the statement of the Truman Doctrine, was an agreement signed on 1947 in Rio de Janeiro whose central principle is that an attack against one is to be considered an attack against all members of the treaty. Since the United States is generally perceived as the main threat to South American countries, CDS is almost a "caution notice" to the Superpower.

In strictly military terms, the South American Defense Council is still a minor coalition against American uncontestable military power. It could virtually be classified as a "soft balancing" initiative. But it is surely a forecasted outcome in our theoretical model. It shows that Brazil acted according to neorealist theory, aggregating South American nations against the influence of great powers.

This section marks the end of our realist causal chain. We are now able to summarize our conclusions and state our main results. Those are the purposes of the next pages.

222 Raymundo Guarino Monteiro, "Uma percepção sobre a segurança hemisférica, a defesa do espaço regional e tropas de paz" (paper presented at IV Encuentro Nacional de Estudios Estratégicos, Buenos Aires, 2001).

${ }^{223}$ Conselho de Defesa Sul-Americano, Estatuto del Consejo de Defensa Suramericano, 2008, Santiago, Chile.

224 Walt, The Origins of Alliance, p. 24. 


\section{CONCLUSION}

Since the early years of the twentieth century, Brazil's major foreign policy aspiration has been to achieve international recognition in accordance with its belief that it should assume its "natural" role as an essential country in world affairs. This ambition is aggregated with a long national will to be independent, to be autonomous. However, the enormousness of its territory and population has not been sufficient to catapult its aspirations in the international system and to be recognized more than just a "Country of the Future".

Notwithstanding, more than 25 years of democracy and political stability have allowed Brazil to make major strides in economic development, including cutting its official poverty rate by half. Brazil became the world's seventh-largest economy and had successfully lifted millions out of extreme poverty. By July 2011, President Lula da Silva attributed the country's newfound success to a "higher power".

The objective of this work was to assess in what extent Brazilian growth and pursuit of more space in the international system is being performed according to the neorealist approach to international relations. In order to accomplish this objective, we established Kenneth Waltz's main variables that should represent a scenario of change in the arrangement of the international system. For the sake of analysis enrichment, we incorporated some insights from neoclassical realists. These insights modified our diagram to incorporate other factors accountable to a country's approach to the international system. In our case, we could determine that Brazil is in fact a revisionist state that has long aspired for a prominent role in the international system. However, this protracted determination alone could not explain a greater assertiveness of Brazil towards status quo powers. The increase in relative power was the trigger, the independent variable to cause this "revision".

That is precisely the reason why the first factor we analyzed encompass a change in Brazil's relative power. Our analysis showed that this was the preponderant factor to foster Brazilian aspirations in the international system. Brazil's increase in economic and soft power from the 2000s had boosted the country's ambition for a bigger role in the international system. As Fareed Zakaria argues, as a state's relative power increases, it attempts to expand its interests and influence abroad ${ }^{225}$. Part of

225 Zakaria, "Realism and Domestic Politics", p. 188. 
this process is almost involuntary; a growing state naturally acquires more economic and political interests in the outside world, often colliding against the interests of other states. As Brazil climbed to higher rungs of the international ladder, it is trying to change the international system in accordance with its own interests.

Our framework defined three variables that could influence Brazilian revisionist behavior: its perceptions of international constraints or insecurities, Brazil's domestic context and the strength of its main goals.

Brazil perceptions of constraints derive naturally from the massive impact the United States exerts in South America. The long-standing U.S. engagement in all Latin America had always elicited negative reactions among the countries of the region. The problem was intensified by a perception of a major sovereignty threat caused by the American decision to reconstitute the Fourth U.S. Fleet in 2008, by the U.S. military presence in the region and by the conviction, stressed mainly by the militaries, that the natural resources of the subcontinent are object of American greediness. Security concerns is a strong factor influencing Brazilian behavior, nevertheless, it could not account for it per se.

Brazil's domestic context is our second factor and also contributed to set in motion a revisionist posture. Left-wing leaders are increasingly influential in Latin America and one common element of these governments is a clear break with the "Washington consensus". These leaderships have a frank antipathy against the United States, mainly due to its cooperation with military regimes in South America from the 1960 s to the 1980 s.

According to our model, the latent Brazilian ambition to revise the arrangement of the international system, after receiving stimulus from these three intervening factors, should drive Brazil to enhance its strength through internal balancing or external balancing.

In our study, we do not perceive an assertive movement towards internal balancing. The stable regional environment in which Brazil is inserted shaped the perceptions of the Brazilian elites, for whom the main external vulnerabilities are perceived as being economic, not military. This explains why Brazil's military expenditures as a percent of GDP is relatively low, and why it is not among the world's great military powers. Nevertheless, a weak movement towards internal balancing is 
perceived in the advance of some military programs, like the development of an indigenous nuclear submarine and the acquisition of modern fighter aircrafts.

As for external balancing, the creation of the South American Defense Council, settled by the Brazilian government, is a sharp reflex of this behavior, although ineffective in practical terms. Brazilian initiatives of external balancing are highly pronounced in terms of "soft balancing", by the means of diplomatic coalitions, international institutions and agreements.

We conclude this study confirming that Brazilian growth and pursuit of more space in the international arena is being performed according to the neorealist approach to international politics. We saw how Brazil covered all the features of our causal chain. Balancing behavior although, due to a stable regional environment in which Brazil is inserted, is not strongly enforced yet. Even though, Brazilian discourse, which repeatedly presents the words "peaceful" and "cooperation" to project a nonwar-like behavior, is slowly being conformed to the pressures of the system. The coyness concerning military capacity is changing in a slow pace. But Brazilian leaderships perceive that a state that is eager to occupy more space in the system, will eventually conflict with other states interests, forcing a strengthen in its military capacity. President Rousseff's words demonstrate that the country already understands this dilemma:

"Brazil assumed in recent years, a great relevance. A country like Brazil has this merit of being a peaceful country. This does not relieve us of having a defense industry and we have a whole contribution to make in ensuring our sovereignty, and inserting increasingly more peacefully and preventive deterrent in the international scenario."226

The conflict between a prolonged peaceful discourse, against the "pressures of the international system" to embrace Realpolitiks is flagrant in Brazil's conduct. But also flagrant is the submission, even if in a slow pace, to the politics of great world powers.

${ }^{226}$ Rousseff, "Discurso na Cerimônia de Inauguração". 


\section{CONCLUSÃO}

Desde os primeiros anos do século $\mathrm{XX}$, a principal ambição na política externa brasileira tem sido a de obter reconhecimento internacional, em consonância com sua crença de que o país deve assumir seu "natural" papel de estado essencial para as principais questões mundiais. Esta aspiração é combinada com um longo desejo nacional de ser independente, de se mostrar um país autônomo. A vasta dimensão do território brasileiro e de sua população não vinham sendo suficientes para catapultar essas aspirações no sistema internacional e para reconhecer-se no Brasil mais do que apenas um "País do Futuro".

Entretanto, mais de 25 anos de democracia e de estabilidade política permitiram ao Brasil fazer grandes avanços no campo do desenvolvimento econômico, como o corte na taxa de pobreza oficial pela metade. O Brasil se tornou a sétima maior economia mundial e conseguiu resgatar, com sucesso, milhões de pessoas da pobreza extrema. Em julho de 2011, o presidente Lula da Silva atribuía o sucesso recente do país a um "poder maior".

Nosso trabalho teve como objetivo avaliar em que medida o crescimento brasileiro e a busca de mais espaço no sistema internacional estão sendo realizados de acordo com a abordagem neorrealista de relações internacionais. A fim de alcançarmos este objetivo, identificamos as principais variáveis na teoria de Kenneth Waltz, que, traduzidas em um diagrama, representam um cenário de mudança no arranjo do sistema internacional. Por uma questão de enriquecimento da análise, foram incorporados alguns conceitos dos realistas neoclássicos. Esses conceitos modificaram nosso diagrama para incorporar outros fatores determinantes na abordagem de um país para o sistema internacional. No caso brasileiro, foi possível determinar que o país é, de fato, um estado revisionista que há muito ambicionava um papel de maior relevo no sistema internacional. No entanto, esta determinação prolongada por si só não pode explicar a maior assertividade brasileira em relação às potências já estabelecidas. $O$ aumento em poder relativo foi o gatilho, a variável independente que causou essa "revisão".

Essa é exatamente a razão pela qual o primeiro fator a analisarmos foi a mudança no poder relativo do Brasil. Nossa análise mostrou que este foi o fator preponderante para a promoção das aspirações brasileiras no sistema internacional. 
O aumento em poder econômico e em soft power do Brasil a partir da década de 2000 impulsionou a ambição do país em direção a um papel mais importante no sistema internacional. Conforme argumenta Fareed Zakaria, com o aumento de poder relativo de um estado, esse busca expandir seus interesses e influência no sistema internacional ${ }^{227}$. Parte deste processo é quase involuntário; um estado em ascensão passa a ter naturalmente mais interesses econômicos e políticos no mundo exterior, muitas vezes colidindo com os interesses de outros estados. Como o Brasil ascendeu para degraus mais altos na escada internacional, o país está tentando mudar o sistema internacional de acordo com seus próprios interesses.

Nosso diagrama definiu três variáveis que poderiam influenciar 0 comportamento revisionista brasileiro: suas percepções dos constrangimentos internacionais ou inseguranças, o contexto doméstico do país e a força dos principais objetivos nacionais.

As percepções brasileiras para suas limitações são naturalmente derivadas do enorme impacto que os Estados Unidos exercem na América do Sul. O longo envolvimento dos EUA em toda a América Latina sempre provocou reações negativas entre os países da região. O problema é intensificado por ter sido percebida como uma grande ameaça à soberania dos países a decisão americana de reconstituir sua Quarta Frota em 2008. Da mesma forma, pela presença militar dos EUA na região, e pela convicção, salientada principalmente pelos militares, de que os recursos naturais do subcontinente são objetos da cobiça americana. As preocupações de segurança são um forte fator de influência sobre o comportamento brasileiro, porém não poderiam explicá-lo por si só.

O contexto doméstico do Brasil é o nosso segundo fator e também contribuiu para pôr em marcha uma postura revisionista. Líderes de esquerda são cada vez mais influentes na América Latina e um elemento comum a esses governos é a clara ruptura com o "Consenso de Washington". Essas lideranças têm uma franca antipatia contra os Estados Unidos, motivados, principalmente, por sua cooperação com os regimes militares na América do Sul dos anos 1960 a 1980.

De acordo com o nosso modelo, a latente ambição brasileira de rever o arranjo do sistema internacional, tendo recebido o estímulo desses três fatores intervenientes, deveria conduzir o país a um fortalecimento interno e externo.

227 Zakaria, "Realism and Domestic Politics", p. 188. 
Em nosso estudo, não percebemos um movimento agressivo em direção ao fortalecimento interno. O ambiente regional estável no qual o Brasil está inserido moldou as percepções das elites brasileiras, para as quais as principais vulnerabilidades externas são percebidas como sendo de natureza econômica, e não militar. Isso explica por que os gastos militares do Brasil como percentual do Produto Interno Bruto é relativamente baixo, e por que o país não está entre as grandes potências militares do mundo. No entanto, percebe-se um leve movimento no sentido do fortalecimento interno ao observarmos o avanço de alguns programas militares, como o desenvolvimento de um submarino nuclear nacional e a aquisição de modernas aeronaves de ataque.

Em relação ao fortalecimento externo, a criação do Conselho de Defesa SulAmericano, conduzido pelo governo brasileiro, é um reflexo nítido desse comportamento, apesar de ineficiente em termos práticos. Iniciativas brasileiras de equilíbrio externo são bastante evidentes em termos de "soft balancing", utilizando-se de alianças diplomáticas, instituições internacionais e acordos.

Concluímos este estudo confirmando que o crescimento brasileiro e sua busca por mais espaço no cenário internacional estão ocorrendo de acordo com a abordagem neorrealista de relações internacionais. Vimos como o Brasil cobriu todas as particularidades de nossa cadeia causal. Todavia, em função do ambiente regional estável no qual o Brasil está inserido, o fortalecimento de capacitação militar ainda não foi significativamente enfatizado. Ainda assim, o discurso brasileiro, que repetidamente apresenta as palavras "pacífico" e "cooperação" para projetar uma atitude não bélica, está lentamente se conformando às pressões do sistema. $O$ acanhamento associado à capacidade militar do país vem mudando em ritmo lento. Porém as lideranças brasileiras já percebem que um estado que almeja ocupar maior espaço no sistema, irá, eventualmente, entrar em conflito com os interesses de outros estados, sendo naturalmente compelido a um reforço em sua capacidade militar. As palavras da presidente Dilma Rousseff demonstram que o país já entende este dilema:

"O Brasil assumiu, nos últimos anos, uma grande relevância. Um país como o Brasil tem esse mérito de ser um país pacífico. Isso não nos livra de termos uma indústria da defesa e temos toda uma contribuição a dar na garantia da nossa soberania, e nos inserirmos cada vez de forma mais pacífica e dissuasória preventivamente no 
cenário internacional. ${ }^{228 "}$

O conflito entre um prolongado discurso pacifista, e as "pressões do sistema internacional" para que se adote a Realpolitiks é flagrante na conduta do Brasil. Mas também flagrante é a submissão, mesmo que em lentos passos, à política das grandes potências mundiais.

${ }^{228}$ Rousseff, "Discurso na Cerimônia de Inauguração". 


\section{REFERENCES:}

Agência Estado. "Brasil Planeja Frota com Seis Submarinos Nucleares." O Estado de São Paulo, Nov. 21, 2010.

Amorim Neto, Octavio. De Dutra a Lula: A Condução e os Determinantes da Política Externa Brasileira. São Paulo: Elsevier, 2011.

Andrade, Letícia Cunha de. "O Brasil em Busca de um Assento Permanente no Conselho de Segurança: Análise Construtivista da Política Externa de 1945 a 2011." Paper presented at 1o Seminário Nacional de Pós-Graduação em Relações Internacionais "Governança e Instituições Internacionais", Brasília, 2012. 1-16.

Baldwin, David A. "Power and International Relations." In Handbook of International Relations, edited by Walter Carlsnaes, Thomas Risse and Beth A. Simmons, 273-297. Los Angeles: Sage, 2013.

Bendel, Thomas Richard. "On the Types of Balancing Behavior." PhD diss., Naval Postgraduate School, Dec. 1994.

Bennett, Andrew, and L. Alexander George. "Process Tracing in Case Study Research." Paper presented at MacArthur Foundation Workshop on Case Study Methods, Cambridge, Oct 17-19, 1997. 1-16.

Brandão, Rafael Vaz da Motta. "O Negócio do Século: O Acordo de Cooperação Nuclear Brasil-Alemanha." Master diss., Universidade Federal Fluminense, 2008.

Brazil, Congresso Nacional. Relatório Final da Comissão Parlamentar Mista de Inquérito destinada a apurar o Programa Autônomo de Energia Nuclear. 1990, Brasília, DF: Senado Federal.

Brazil, Ministério da Defesa. Estratégia Nacional de Defesa. 2008, Brasília.

Brazil, Congresso Nacional. Testimony of Admiral Almirante Maximiano da Fonseca, Former Ministry of Navy. Jun. 21, 1990, Brasilia, DF: Parliamentary Commission of Inquiry held to investigate the Nuclear Energy Autonomous Program.

Brazil, National Security Council. Minutes of the Fortieth Session of the Brazilian National Security Council. Oct. 04, 1967, Brasilia, DF: Archive of Brazilian Foreign Ministry, History and Public Policy Program Digital Archive.

Brazil, National Security Council. Letter from Minister and Secretary-General of the National Security Council, Danilo Venturi to Brazilian President, Revision of the Concepts of the Autonomous Program, Fev. 1985, Brasilia, DF. 
Brulin, Remi. "Operation Condor: Setting precedent from one 'war on terrorism' to the next." Al Jazeera, Sep. 29, 2013.

Burnett, Alistair. "Is Brazil Losing Global Momentum?" Yale Global Online. May 6, 2014. http://yaleglobal.yale.edu/content/brazil-losing-global-momentum (accessed Jan 21, 2015).

Buzan, Barry, and Ole Wæver. Regions and Powers - The Structure of International Security. 8ht ed. Cambridge: Cambridge University Press, 2003.

Buzan, Barry, Ole Wæver, and Jaap de Wilde. Security - A New Framework for Analysis. Boulder: Lynne Rienner Publishers, 1998.

Calloni, Stella. "Los Archivos del Horror del Operativo Cóndor." Equipo Nizkor, 1998. http://www.derechos.org/nizkor/doc/condor/calloni.html\#Avanguardia Nazionale (accessed Nov 28, 2014).

Cantanhêde, Eliana. "Amorim diz que EUA 'pisaram no nosso calo'." Folha de São Paulo, Jan. 23, 2006.

Carr, Edward H. The Twenty Years' Crisis, 1919-1939: An Introduction to the Study of International Relations. New York: Harper Perennial, 1939.

Cepik, Marco. "Segurança na América do Sul: traços estruturais e dinâmica conjuntural." Análise de Conjuntura OPSA, Agosto 2005.

—. "Regional Security and Integration in South America: What UNASUR could learn from the OSCE and the Shanghai Organization experiences?" Paper presented at the Second Global International Studies Conference, Ljubljana, Slovenia, Jul. 23-26, 2008.

Cervo, Amado Luiz, and Clodoaldo Bueno. História da Política Exterior do Brasil. 3rd. ed. Brasília: Editora Universidade de Brasília, 1992.

Chang, Chin-Lung. "A Measure of National Power." The National University of Malaysia, feb. 2004.

Chant, Chris, Steve Crawford, Martin J. Dougherty, and lan Hogg. Weapons of War Submarnes: 1940-Present. New York: Chartwell Books, 2013.

Chatin, Mathilde. "Brazil: a new powerhouse without military strength?" BRICS Policy Center, 2013: 1-25.

Christensen, Steen Fryba. "Brazil's Foreign Policy Priorities." Third World Quaterly 34 , no. 2 (2013): 271-286.

Collier, David. "Understanding Process Tracing." PS: Political Science and Politics 44, no. 4 (Oct. 2011): 823-830. 
Corporación Colectivo de Abogados José Alvear Restrepo. "Empresas

Transnacionales de Seguridad Privada en Colombia. Caso Estudio: Plan

Colombia." Corporación Colectivo de Abogados . Feb. 04, 2008.

http://www.colectivodeabogados.org/IMG/pdf/0802_merc_wisc_esp-2.pdf (accessed Jan. 21, 2014).

Costa, Wanderley Messias. "O Brasil e a América do Sul: cenários geopolíticos e os desafios da integração." Confins 7 (2009).

Costas, Ruth. "Para EUA, Brasil deve trabalhar com Otan." O Estado de São Paulo, Aug. 25, 2007: A19.

Cox, Robert W. "Social Forces, States and World Orders: Beyond International Relations Theory." In Neorealism and Its Critics, edited by Robert O. Keohane, 204-254. New York: Columbia University Press, 1986.

Devereux, Charlie, and Raymond Colitt. "Venezuelans' Quality of Life Improved in UN Index Under Chavez." Bloomberg L.P., Mar. 2013.

Falleti, Tulia G. "Theory-Guided Process-Tracing: Something Old, Something New." APSA-CP, Newsletter of the Organized Section in Comparative Politics of the APSA 17, no. 1 (2006): 9-14.

Fausto, Sergio, and Bernardo Sorj. "O papel do Brasil na América do Sul: estratégias e percepções mútuas." Política Externa 20, no. 2 (2011): 11-22.

Formiga, Marcos. "Brasília supera Londres no número de embaixadas dos países africanos." Conselho Nacional de Desenvolvimento Científico e Tecnológico. Jun. 11, 2013. http://www.cnpq.br/web/guest/noticiasviews//journal_content/56_INSTANCE_a6MO/10157/1076725 (accessed Jan. 21, 2014).

Garat, Jean-Baptiste. "UE-Brésil : Sarkozy veut un partenariat renforcé." Le Figaro Fr, Dec. 2008.

George, Alexander L., and Timothy J. McKeown. "Case Studies and Theories of Organizational Decision Making." Advances in Information Processing in Organizations 2 (1985): 21-58.

Gerner, Deborah J., Philip A. Schrodt, Ronald A. Francisco, and Judith L. Weddle. "Machine Coding of Event Data Using Regional and International Sources." International Studies Quarterly, Mar. 1994: 91-119.

Global Firepower. World Ranking of Power. 2014.

http://www.globalfirepower.com/countries-listing.asp (accessed Dec. 01, 2014).

Goldstein, Joshua S. "A Conflict-Cooperation Scale for WEIS Events Data." The Journal of Conflict Resolution, Jun. 1992: 369-385. 
Hart, Jeffrey. "Three Approaches to the Measurement of Power in International Relations." International Organization 30, no. 2 (1976): 289-305.

Head, Richard G. "Review of: World Power Assessment 1977, A Calculus of Strategic Drift by Ray S. Cline." Foreign Affairs, Apr. 1978.

Hirst, Monica Ellen Seabra. "As Relações Brasil-Estados Unidos Desde Uma Perspectiva Multidimensional: Evolução Contemporânea, Complexidades Atuais e Perspectivas Para o Século XXI." PhD diss., Universidade Federal do Rio Grande do Sul, 2011.

Hurrell, Andrew James. "Security in Latin America." International Affairs vol. 74, no. 3 (1998): 529-546.

-. The Quest for Autonomy: The Evolution of Brazil's Role in the International System, 1964 - 1985. Brasília: Fundação Alexandre de Gusmão, 2013.

Ikenberry, G. John. "The State and Strategies of International Adjustment." World Politics 39, no. 1 (Oct. 1986): 53-77.

Jakobsen, Jo. "Neorealism in International Relations - Kenneth Waltz." Popular Social Science, Nov. 2013.

http://www.popularsocialscience.com/2013/11/06/neorealism-in-internationalrelations-kenneth-waltz/ (accessed Nov 20, 2014).

Jervis, Robert. "Cooperation Under the Security Dilemma." World Politics 30, no. 2 (Jan. 1978): 167-214.

-. Perception and Misperception in International Politics. Princeton: Princeton University Press, 1978.

Kennedy, Paul. "The Great Powers, Then and Now." The New York Times. Aug 13, 2013. http://www.nytimes.com/2013/08/14/opinion/global/the-great-powersthen-and-now.html?_r=0 (accessed Jan 21, 2015).

-. The Rise and Fall of the Great Powers: Economic Change and Military Conflict from 1500 to 2000. New York: Vintage, 1987.

Keohane, Robert O. "Lilliputians' Dilemmas: Small States in International Politics." International Organization 23, no. 2 (1969): 291-310.

Keohane, Robert O., Gary King, and Sidney Verba. Designing Social Inquiry:Scientific Inference in Qualitative Research. Princeton: Princeton University Press, 1994.

Khanna, Parag. "Here Comes the Second World." New Perspectives Quaterly 25, no. 3 (2008). 
Kim, Hyung Min. "Social Network Conceptualizations of International System Structure and National Power: a Social Network Perspective on International Relations." PhD diss., University of North Carolina, 2007.

King, Gary, and Will Lowe. "An Automated Information Extraction Tool for International Conflict Data with Performance Performanceas Good as Human Coders: A Rare Events Evaluation Design." International Organization, 2003: 617-642.

Klein, Naomi. "The World Bank has the perfect standard bearer." The Guardian, Apr. 26, 2007.

Korean Central News Agency (KCNA), Pyongyang. "Report on Implementation of 2009 Budget and 2010 Budget." Korean News. Apr. 09, 2010.

http://kcna.co.jp/item/2010/201004/news09/20100409-10ee.html (accessed Feb. 06, 2014).

Kozloff, Nikolas. Revolution! South America and the Rise of the New Left. New York: Palgrave Macmillan, 2008.

Kuklick, Bruce. Blind Oracles, Intellectuals and War from Kennan to Kissinger. Princeton: Princeton University Press, 2013.

Larson, Deborah Welch, T.V. Paul, and William C. Wohlforth. "Status and World Order." In Status in World Politics, edited by T.V. Paul, Deborah Welch Larson and William C. Wohlforth. New York: Cambridge University Press, 2014.

Lima, Gislene Nogueira. Brics: Potencial de Desenvolvimento e Desafios Para a Construção de Um Novo Cenário Econômico Mundial. São Paulo: Saint Paul, 2012.

Lima, Maria Regina Soares de, and Mônica Hirst. "Brazil as an Intermediate State and Regional Power: Action, Choice and Responsibilities." International Affairs 82, no. 1 (Jan. 2006): 21-40.

Lima, Paulo César Ribeiro. "Os Desafios, os Impactos e a Gestão da Exploração do Pré-Sal." Câmara dos Deputados (Brasil), Nov. 2008.

Lobe, Jim. "Challenges 2006-2007: A Bad Year for Empire." Inter Press Service News Agency, Dec. 2006.

Malamud, Andrés. "A Leader Without Followers? The Growing Divergence Between the Regional and Global Performance of Brazilian Foreign Policy." Latin American Politics and Society 53, no. 3 (2011): 1-24.

Maoz, Zeev, Lesley G. Terris, Ranan D. Kuperman, and Ilan Talmud. "International Relations: a Network Approach." Paper presented at Gilman Conference on New Directions on International Relations. New Haven, 2003. 1-30. 
Mares, David R. Violent Peace - Militarized Intestate Bargaining in Latin America. New York: Columbia University Press, 2001.

Martín, Felix E. "The Militarist Peace in South America, 1935-2003." Paper prepared for delivery at the 2004 Annual Meeting of the American Political Science Association, Sep. 2004.

Mearsheimer, John J. The Tragedy of Great Power politics. New York: Norton, 2001.

Méndez, Alejandro. "UNASUL terá doutrina de defesa independente dos Estados Unidos." Folha de São Paulo, May 27, 2011: 15.

Miroff, Nick. "Latin America's political right in decline as leftist governments move to middle." The Guardian, Jan. 28, 2014.

Moffett, Matt. "Brazil Joins Front Rank of New Economic Powers." Wall Street Journal, May 13, 2008.

Monteiro, Raymundo Guarino. "Uma percepção sobre a segurança hemisférica, a defesa do espaço regional e tropas de paz." Lecture prepared for the IV Encuentro Nacional de Estudios Estratégicos, Buenos Aires, 2001.

Morgenthau, Hans J. Politics Among Nations. 2nd ed. New York: Alfred A. Knopf, 1956.

Narang, Viping. Nuclear Strategy in the Modern Era, Regional Powers and International Conflict. Princeton: Princeton University Press, 2014.

Nathan, Laurie. "Security Communities and The Problem of Domestic Instability." Crisis States Research Center - LSE. 2004. http://eprints.Ise.ac.uk/28204/ (accessed Jul. 07, 2013).

Nedal, D. K. "US Diplomatic Efforts Stalled Brazil's Nuclear Program in 1970." Nuclear Proliferation International History Project. Wilson Center. 2013. http://www.wilsoncenter.org/publication/us-diplomatic-efforts-stalled-brazilsnuclear-program-1970s (accessed Jan. 21, 2014).

Nye, Joseph S. "The Decline of America's Soft Power." Foreign Affairs, May 2004.

-. The Future of Power. New York: PublicAffairs, 2010.

Obama, Barack. "Remarks by the President to the People of Brazil in Rio de Janeiro, Brazil." The White House, Mar 20, 2011.

Onis, Juan de. "Brazil's Big Moment: A South American Giant Wakes Up." Foreign Affairs 87, no. 6 (2008): 110-122.

Organski, Abramo Fimo Kenneth, and Jacek Kugler. The War Ledger. Chicago: University of Chicago Press, 1980. 
Pape, Robert A. "Soft Balancing against the United States." International Security 30, no. 1 (2005): 7-45.

Parsi, Trita. A Single Roll of the Dice: Obama's Diplomacy with Iran. New Haven: Yale University Press, 2013.

Patriota, Antonio de Aguiar. "Welcoming Speech." Seminar: A América do Sul e a Integração Regional. Rio de Janeiro: Fundação Alexandre de Gusmão, 2011.

Patti, Carlos. "O programa nuclear brasileiro entre passado e futuro." Boletim Meridiano 47, no. 14 (2013): 49-55.

Paul, T.V., and Mahesh Shankar. "Status Accomodation through Institutional Means: India's Rise and the Global Order." In Status in World Politics, edited by T.V. Paul, Deborah Welch Larson and William C. Wohlforth. New York: Cambridge University Press, 2014.

Pimentel, Carolina. "Militares brasileiros visitarão países da América Latina para articular plano de defesa para região." Agência Brasil, Oct. 23, 2007.

Pinheiro, Letícia. "Traídos pelo Desejo: um Ensaio sobre a Teoria e a Prática da Política Externa Brasileira Contemporânea." Contexto Internacional 22, no. 2 (2000): 305-335.

Powell, Robert. "Anarchy in International Relations Theory: The Neorealist-Neoliberal Debate." International Organization, 1994: 313-344.

Press, Daryl. Calculating Credibility: How Leaders Assess Military. Ithaca: Cornell University Press, 2005.

R Development Core Team. "R: A Language and Environment for Statistical Computing." R Foundation for Statistical Computing. 2013. http://www.Rproject.org (accessed Jan. 21, 2014).

Red de Seguridad y Defensa de América Latina. Atlas Comparativo de la Defensa en América Latina y Caribe. Buenos Aires: RESDAL, 2014.

Romero, Simon. "Brazil Military Drills to Defend Amazon." The New York Times, Nov. 8, 2014.

Rose, Gideon. "Neoclassical Realism and Theories of Foreign Policy." World Politics 51, no. 1 (1998): 144-172.

Rosecrance, Richard. "Reply to Waltz." International Organization 36, no. 3 (1982): 682-685.

Rousseff, Dilma. "Discurso na Cerimônia de Inauguração da Unidade de Fabricação de Estruturas Metálicas - UFEM", Itaguai, RJ, Mar. 01, 2013. 
-. "Statement at the Opening of the General Debate of the 66th Session of the United Nations General Assembly." New York, NY, Sep. 21, 2011.

Sagan, Scott D. "Why Do States Build Nuclear Weapons? Three Models in Search of a Bomb." International Security 21, no. 3 (1996-1997): 54-86.

Salek, Silvia. "Brazil: No longer 'Country of the Future'." BBC News, Mar. 06, 2012.

Saraiva, José Flávio Sombra. "Autonomia na Inserção Internacional do Brasil: Um Caminho Histórico Próprio." Contexto Interancional, 2014: 9-41.

Sarkees, Meredith Reid. "The COW Typology of War: Defining and Categorizing Wars". CQ Press, 2010.

http://cow.la.psu.edu/COW2\%20Data/WarData_NEW/COW\%20Website\%20\%20Typology\%20of\%20war.pdf (accessed Sep. 15, 2013).

Sarney, José. "No Clube dos Nove." Biblioteca Digital do Senado Federal. Edited by Senado Federal. Sep. 04, 1987. http://www2.senado.leg.br/bdsf/handle/id/443582 (accessed Jan. 15, 2014).

Sayer, Andrew. Method in Social Science: A Realist Approach. London: Routledge, 1992.

Schrodt, Philip A. CAMEO: Conflict and Mediation Event Observations - Event and Actor Codebook. University Park: Event Data Project - Pennsylvania State University, 2012.

Schrodt, Philip A. "Event Data in Foreign Policy Analysis." In Foreign Policy Analysis: Continuity and Change in Its Second Generation, edited by Laura Neack, Patrick J. Haney and Jeanne A. K. Hey, 1-28. New York: Prentice Hall, 1993.

—. "GDELT: Global Data on Events, Location and Tone." Prepared for Workshop at the Conflict Research Society, Colchester, UK, Sep. 16-20, 2013.

Schweller, Randall L. "Neorealism's Status Quo Bias: What Security Dilemma?" Security Studies 5, no. 3 (1996): 90-121.

Senhoras, Elói Martins. "O Conselho Sul-Americano de Defesa e as Percepções da Construção da Segurança Cooperativa no Complexo Regional da América do Sul." In Retos a la Seguridad y Defensa en un Ambiente Político Complejo: Cooperación y Divergencia en Suramérica. Cartagena: Centro de Estudios Hemisféricos de Defensa, 2009.

Serrão, Nathalie Torreão, and Waldimir Pirró e Longo. "Avaliando o Poder Nacional." Revista da Escola de Guerra Naval, jan./jun. 2012: 17-42.

Silva, Luís Inácio Lula da. "O Brasil no mundo: mudanças e transformações." Statement at Conferência Nacional 2003-2013: Uma Nova Política Externa. São Bernardo do Campo, SP, Jul. 15-18, 2014. 169-178. 
Silva, M. N. "Brazil's Monroe Doctrine." The Westphalian Post, Dec. 22, 2010. http://westphalianpost.wordpress.com/2010/12/22/brazils-monroe-doctrine/ (accessed Nov. 07, 2014).

Singer, J. David, Stuart Bremer, and John Stuckey. "Capability Distribution, Uncertainty, and Major Power War, 1820-1965." In Peace, War, and Numbers, edited by Bruce Russett. Beverly Hills: Sage, 1972.

Smith, Peter H. Talons of the Eagle - Dynamics of U.S. Latin American Relations. New York: Oxford University Press, 2000.

Stalcup, Travis. "What is Brazil up to With Its Nuclear Policy?" Georgetown Journal of International Affairs, Oct. 2012.

Stewart-Ingersoll, Robert, and Derrick Frazier. Regional Powers and Security Orders - A theoretical framework. New York: Routledge Global Security Studies, 2012.

Stockholm International Peace Research Institute. "Military Expenditure Database." Stockholm International Peace Research Institute. 2014. http://www.sipri.org/research/armaments/milex/milex_database (accessed Dec. 01, 2014).

Sweig, Julia E. "A New Global Player: Brazil's Far-Flung Agenda." Foreign Affairs 89, no. 6 (2010): 173-184.

Tanno, Grace. "A Contribuição da Escola de Copenhage aos Estudos de Segurança Internacional." Contexto Internacional 25, no. 1 (2003): 47-80.

Taylor, Paul D. "Why Does Brazil Need Nuclear Submarines?" U.S. Naval Institute 135, no. 6 (Jun. 2009): 1276.

Tellis, Ashley, Janice Bially, Christopher Layne, Melissa McPherson, and Jerry Sollinger. Measuring National Power in the Postindustrial Age: Analyst's Handbook. Santa Monica, CA: RAND, 2000.

Treverton, Gregory F., and Seth G. Jones. Measuring National Power. Santa Monica, CA: RAND, 2005.

Trunkos, Judit. "What is Soft Power Capability and How Does It Impact Foreign Policy?" PhD diss., University of South Carolina, 2013.

UNDP - RLAC. Analyzing Conflict, Democracy and Violence in Colombia. Edited by Marc Chernick. Georegtown University and United Nations Development Programme-Region, 2005.

US Department of Defense. Base Structure Report. Washington: DoD, 2014. 
US National Archives and Records Administration. "US Embassy Cable: Brazilian Public Reaction to US Nuclear Policies." Washington, DC: History and Public Policy Program Digital Archive, Nov. 19, 1976.

Van Evera, Stephen. "Primed For Peace: Europe After the Cold War." International Security 15, no. 3 (1990).

Vaz, Alcides Costa, ed. Intermediate States, Regional Leadership and Security: India, Brazil and South Africa. Brasília: Editora UnB, 2006.

Veen, Tim. "Event Data: A method for analysing political behaviour in the EU." Prepared for the Fourth Pan-European Conference on EU Politics, Riga, Latvia, Sep. 25-27, 2008.

Vidigal, Armando Amorim Ferreira. "Integração Sul-Americana: Segurança Regional e Defesa Nacional." Caderno Premissas 14 (Dec. 1996): 103-138.

Vigevani, Tullo, and Gabriel Cepaluni. "A Política Externa de Lula da Silva: a Estratégia da Autonomia pela Diversificação." Contexto Internacional 29, no. 2 (2007): 273-335.

Vigevani, Tullo, Gustavo Favaron, Haroldo Ramanzini Júnior, and Rodrigo Correia. "O papel da integração regional para o Brasil: universalismo, soberania e percepção das elites." Revista Brasileira de Política Internacional 51, no. 1 (2008).

Walt, Stephen M. "Alliance Formation and the Balance of World Power." International Security 9, no. 4 (1985).

—. "The Top 5 Foreign Policy Lessons of the Past 20 Years." Foreign Police, Nov. 18, 2014. http://foreignpolicy.com/2014/11/18/the-top-5-foreign-policy-lessonsof-the-past-20-years/ (accessed Nov. 14, 2014).

—. The Origins of Alliances. Ithaca: Cornell University Press, 1987.

Waltz, Kenneth N. "A Response to My Critics." In Neorealism and its Critics, edited by Robert O. Keohane. New York: Columbia university Press, 1986.

—. "Evaluating Theories." American Political Science Review 91, no. 4 (Dec. 1997): 913-917.

—. "International Politics is not Foreign Policy." Security Studies 6, no. 1 (1996): 5457.

—. Man, the State and War. New York: Columbia University Press, 1959.

—. "Realist Thought and Neorealist Theory." Journal of International Affairs 44, no. 1 (Mar. 1990): 21. 
—. "Structural Realism after the Cold War." International Security 25, no. 1 (2000): 541.

—. "The Origins of War in Neorealist Theory." Journal of Interdisciplinary History 18, no. 4 (1988): 615-628.

—. Theory of International Politics. Reading, MA: Addison-Wesley Pub. Co., 1979.

Yonamine, James E. Predicting Future Levels of Violence in Afghanistan Districts Using GDELT. Jay Yonamine. Apr. 21, 2013. http://jayyonamine.com/wpcontent/uploads/2013/04/Predicting-Future-Levels-of-Violence-in-AfghanistanDistricts-using-GDELT.pdf (accessed Nov. 29, 2014).

Yonamine, James E., and Philip A. Schrodt. "A Guide to Event Data: Past, Present and Future." Paper not published, 2011.

Zakaria, Fareed. From Wealth to Power. The Unusual Origins of America's World Role. Princeton: Princeton University Press, 1998.

Zakaria, Fareed. "Realism and Domestic Politics: A Review Essay." International Security 17, no. 1 (1992): 177-198.

Zivec, Stephan. "Brazilian Nuclear Submarine, Project to consolidate Brazil's Global Leadership." IDC Herzliya - Seminar course: Regional Security in a Comparative Perspective, 2013: 1-28.

Zoglin, Katie. "Paraguay's Archive of Terror: International Cooperation and Operation Condor." The University of Miami Inter-American Law Review 32, no. 1 (2001): 57-82.

Zweig, Stefan. Brasil, País do Futuro. Rio de Janeiro: Ridendo Moraes, 1941. 